INTER NATIONAL MONETARY FUND
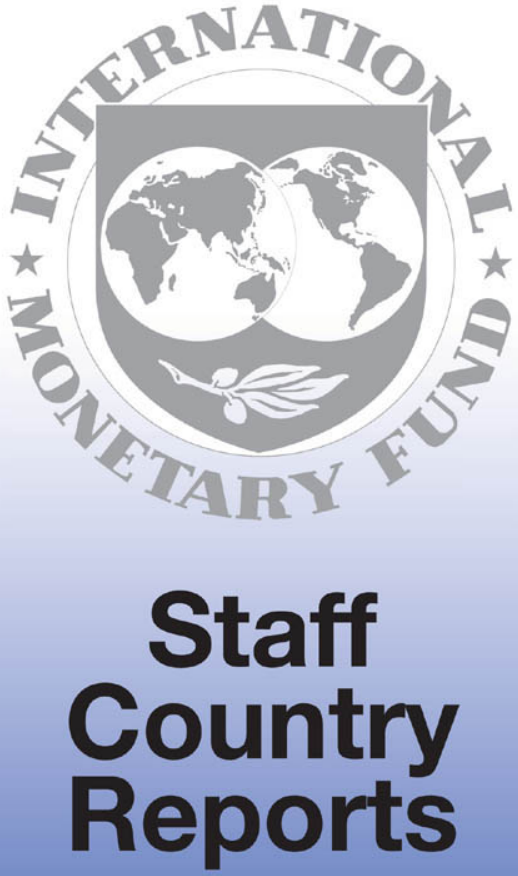


\section{South Africa: Financial System Stability Assessment, Including Report on the Observance of Standards and Codes on the following topic: Securities Regulation}

This Financial System Stability Assessment on South Africa was prepared by a staff team of the International Monetary Fund and the World Bank as background documentation for the periodic consultation with the member country. It is based on the information available at the time it was completed on August 19, 2008. The views expressed in this document are those of the staff team and do not necessarily reflect the views of the government of South Africa or the Executive Board of the IMF.

The policy of publication of staff reports and other documents by the IMF allows for the deletion of market-sensitive information.

Copies of this report are available to the public from

International Monetary Fund • Publication Services

700 19th Street, N.W. • Washington, D.C. 20431

Telephone: (202) 623-7430 • Telefax: (202) 623-7201

E-mail: publications@imf.org • Internet: http://www.imf.org

Price: $\$ 18.00$ a copy

\section{International Monetary Fund Washington, D.C.}


This page intentionally left blank 
INTERNATIONAL MONETARY FUND

SOUTH AFRICA

Financial System Stability Assessment

\author{
Prepared by the Monetary and Capital Markets and African Departments
}

Approved by Hervé J. Ferhani and Antoinette M. Sayeh

August 19, 2008

A joint IMF-World Bank Financial Sector Assessment Program (FSAP) mission visited South Africa from May 6 to 20, 2008 to conduct an FSAP Update. The mission findings were discussed with the authorities during the Article IV Consultation mission in June 2008. The mission comprised Ann Rennie (Co-Mission Chief, World Bank); S. Kal Wajid (Co-Mission Chief, MCM); Federico Galizia, Ian Tower, Alexander Tieman, and Jérôme Vacher (all MCM); Bernie Egan (consultant, IMF), Robert Burgess (AFR); Greg Brunner, Katherine McKee, Carlos Cuevas, Jonathan Katz, and Loic Chiquier (World Bank).

Sean Nolan, the Fund's Senior Resident Representative for South Africa also participated in some of the meetings. The mission's main findings are:

- South Africa's sophisticated financial system is fundamentally sound and has so far weathered the global financial market turmoil without major pressures. Banks and insurance companies have enjoyed good profitability, capitalization levels, and reserves.

- However, the system faces heightened macro-financial risks and financial institutions are bracing for a less benign environment. Banks are exposed to increased credit risk, given record household indebtedness and mounting debt service burden and are seeing some impairment of asset quality. Stress tests suggest that capital and reserve cushions at banks and insurance companies are sufficient to absorb large shocks.

- The financial sector regulatory framework is modern and generally effective. There is a need to strengthen supervision of conglomerates with a focus on risks that span more than one sector, and to further promote cooperation, consistency, and effectiveness among regulators.

- The framework for securities regulation has been enhanced, but there is a need to strengthen surveillance of over-the-counter (OTC) markets and for improved monitoring of listed company disclosure.

The main author of this report is S. Kal Wajid, with substantial contributions from the FSAP team.

FSAP assessments are designed to assess the stability of the financial system as a whole and not that of individual institutions. They have been developed to help countries identify and remedy weaknesses in their financial sector structure, thereby enhancing their resilience to macroeconomic shocks and cross-border contagion. FSAP assessments do not cover risks that are specific to individual institutions such as asset quality, operational or legal risks, or fraud. 
Glossary

Executive Summary $\underline{6}$

I. Macroeconomic Setting and Risks .............................................................................

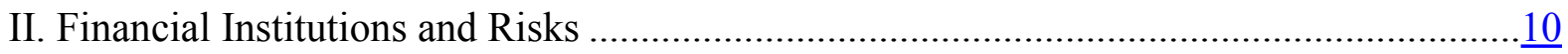

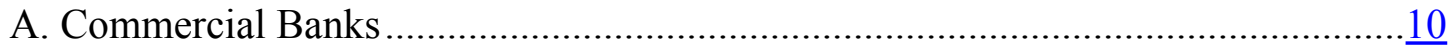

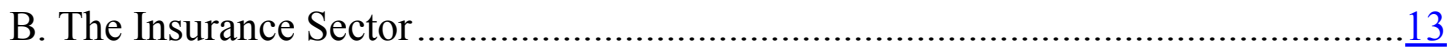

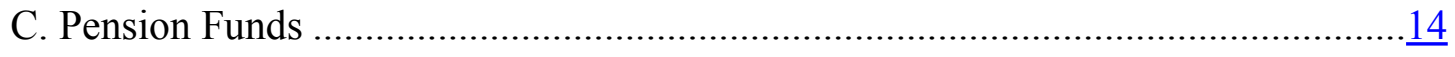

III. Financial Markets, Infrastructure, and Safety Nets ……………………………..........

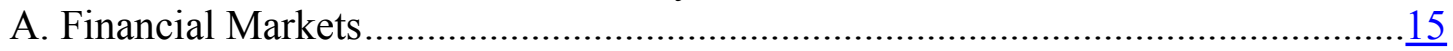

B. Systemic Liquidity Management ……………………..................................19

C. Crisis Management and Safety Nets ……………………………………….......

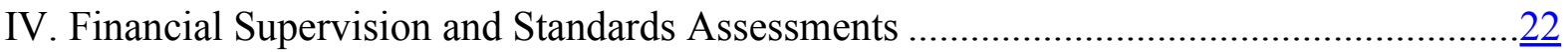

A. The Supervisory and Regulatory Framework ……………………………….......22

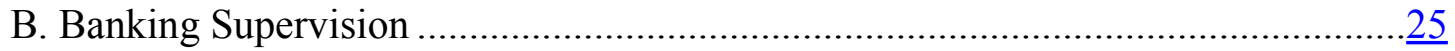

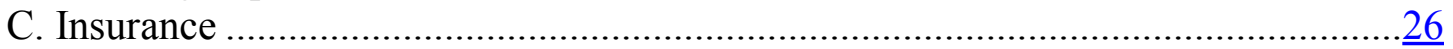

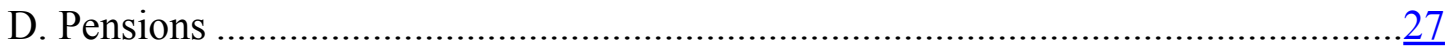

E. IOSCO Assessment of Securities Markets .........................................................27

F. National Credit Regulator..............................................................................

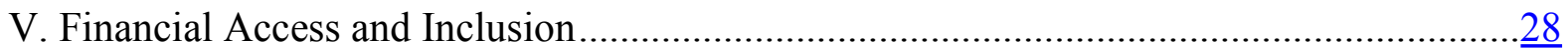

A. Recent Performance and the Financial Sector Charter …………………………....28

B. Housing Finance..............................................................................................

Tables

1. Summary Implementation of the IOSCO Principles ……..................................................

2. Recommended Action Plan to Improve Implementation of the IOSCO ……......................

Figures

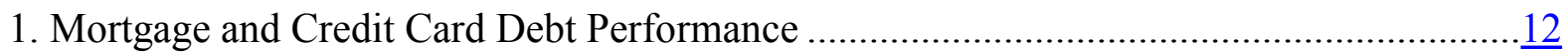

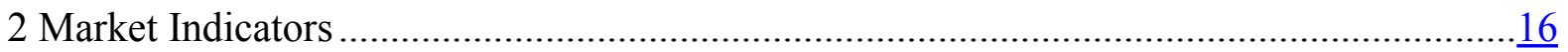

3. Composition of Listing on the Bond Exchange of South Africa ……...............................17

4. Selected Countries: Size of Spot Foreign Exchange Markets and OTC ..............................19

5. Regulatory and Supervisory Structure for the Financial Sector .......................................24

6. Selected Household Indicators..................................................................................

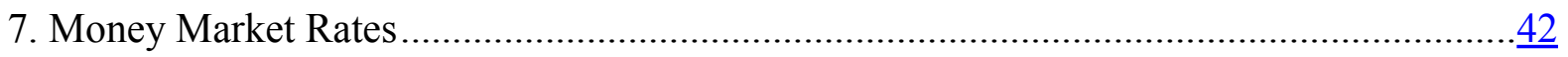

8. SARB Liquidity Draining Operations ……………......................................................

9. Financial System Development Indicators ………….....................................................44 


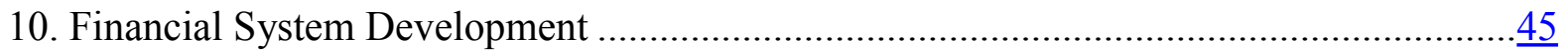

11. Market Risk Stress Tests for the Banks ....................................................................

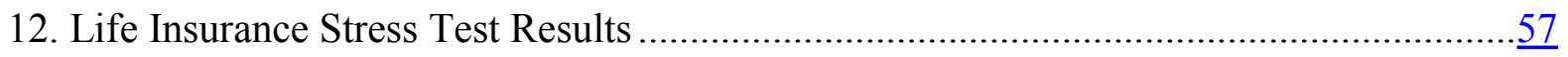

Box

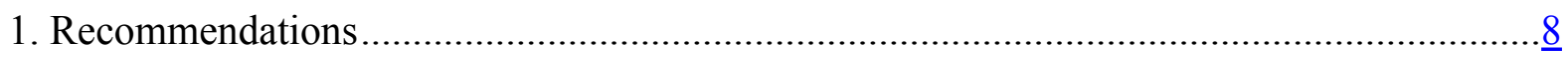

Appendices

I. Selected Macroeconomic and Financial Indicators .......................................................

II. Stress Testing Coverage and Results ......................................................................

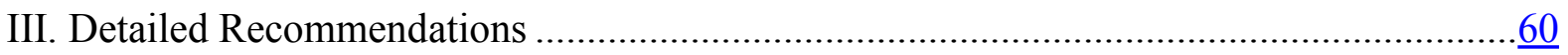

Appendix Tables

3. Selected Economic and Financial Indicators, 2003-09 .................................................

4. Financial Soundness Indicators, 2002-07 .................................................................... 40

5. Selected Indicators for the Corporate Sector ………................................................... 40

6. Pension Funds, Insurers, and Unit Trusts ...................................................................

7. Selected Indicators for the Insurance Sector, 2006-07 ……............................................

8. Institutional Investors, Corporates, and Household Deposits.............................................. 42

9 Single-Factor Market Risk Shocks for Banks................................................................. 49

10. Single-Factor Market and Insurance Risk Shocks …….............................................

11. Single-Factor Credit Risk Shocks for the Banks ……...................................................

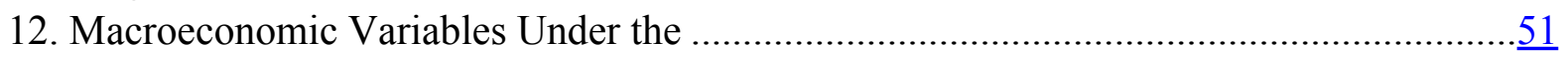

13. Market Risks Stress Tests for the Banks.................................................................

14. Market and Insurance Risk Stress Tests ……………............................................

15. Credit Risk Stress Tests for the Banks...................................................................

Annex

1. Observance of Financial Sector Standards and Codes - Summary IOSCO Assessment .... $\underline{30}$ 


\section{GLOSSARY}

\begin{tabular}{|c|c|}
\hline $\mathrm{ABCP}$ & Asset-backed commercial paper \\
\hline ABSA & Amalgamated Bank of South Africa \\
\hline $\mathrm{ACI}$ & Association of Collective Investments \\
\hline ATM & Automatic teller machine \\
\hline $\mathrm{BCP}$ & Basel Core Principle \\
\hline BESA & Bond Exchange of South Africa \\
\hline BSD & Bank Supervision Department \\
\hline $\mathrm{BU}$ & Bottom-up stress testing \\
\hline CAR & Capital adequacy ratio \\
\hline CPI & Consumer Price Index \\
\hline DFI & Development Finance Institution \\
\hline DTI & Department of Trade and Industry \\
\hline FAIS & Financial Advisory and Intermediary Services Act \\
\hline FSAP & Financial Sector Assessment Program \\
\hline FSB & Financial Services Board \\
\hline FSC & Financial Sector Charter \\
\hline FSDU & Financial Sector Development Unit \\
\hline FSOS & Financial Services Ombuds Schemes \\
\hline GDP & Gross domestic product \\
\hline IRB & Internal ratings based \\
\hline IRBA & Independent Regulatory Board for Auditors \\
\hline JIBAR & Johannesburg Interbank Agreed Rate \\
\hline JSE & Johannesburg Stock Exchange \\
\hline LOLR & Lending-of-the-last-resort \\
\hline MOF & Minister of Finance \\
\hline MOU & Memorandum of Understanding \\
\hline $\mathrm{NCA}$ & National Credit Act \\
\hline NCR & National Credit Regulator \\
\hline NHFC & National Housing Finance Corporation \\
\hline NPLs & Nonperforming loans \\
\hline NT & National Treasury \\
\hline
\end{tabular}




$\begin{array}{ll}\text { NURCHA } & \text { National Urban Reconstruction and Housing Agency } \\ \text { OECD } & \text { Organization for Economic Cooperation and Development } \\ \text { OMB } & \text { Old Mutual } \\ \text { OTC } & \text { Over-the-counter } \\ \text { PDs } & \text { Probability of defaults } \\ \text { RHLF } & \text { Rural Housing Loan Fund } \\ \text { RMBS } & \text { Residential mortgage-backed security } \\ \text { SADIS } & \text { South African Deposit Insurance Scheme } \\ \text { SARB } & \text { South African Reserve Bank } \\ \text { SME } & \text { Small- and medium-sized enterprises } \\ \text { SROs } & \text { Self-Regulatory Organizations } \\ \text { TD } & \text { Top-down stress testing }\end{array}$




\section{EXECUTIVE SUMMARY}

South Africa's sophisticated financial system is fundamentally sound. The system is diversified and spans a broad range of activities that are supported by an elaborate legal and financial infrastructure and a generally effective regulatory framework. Financial institutions have benefited from a prolonged economic expansion, supported by prudent macroeconomic management and high commodity prices. The system has weathered the global financial market turmoil without major pressures. Banks and insurance companies have enjoyed good profitability, capitalization levels, and reserves.

However, the system faces increased macro-financial risks and financial institutions are bracing for a less benign environment. Banks are facing increased credit risk, especially in their household loan portfolios, given record household indebtedness and mounting debt service burden. Banks are also seeing some impairment of asset quality and returns while continuing to rely heavily on domestic wholesale deposits. Stress tests, however, show that capital and reserve cushions at banks and insurance companies are adequate to absorb large but plausible shocks.

Money, foreign exchange, and capital markets are relatively well-developed but may be subject to contagion risks given their close linkages with offshore markets. The significant role of nonresident inflows in the stock and bond exchanges underscores their susceptibility to changes in investor sentiments, placing a premium on policies that induce investor confidence. OTC market activity in foreign exchange derivative products has been expanding, although its offshore component is difficult to gauge due to a lack of information and regulatory oversight. The mission supports steps to foster liquidity and depth in the local markets and to attract foreign direct investment inflows. The authorities should continue their cautious approach to foreign exchange regime liberalization with due regard to macroeconomic circumstances.

The framework for contingency planning and emergency liquidity assistance has been strengthened. The establishment of the Financial Sector Contingency Forum facilitates preparedness for addressing crises and inter-agency coordination. The South African Reserve Bank (SARB) has also enhanced its liquidity assistance mechanisms. However, the framework for bank intervention and resolution could be further enhanced by the implementation of a well-designed deposit insurance system and authorizing the registrar of banks to appoint a curator for failing institutions.

The regulatory framework for the financial sector is modern and generally effective. SARB's early implementation of Basel II has proceeded well and the Financial Services Board (FSB's) licensing, supervision, and enforcement capacity as well as its overall resources have been enhanced. Model validation and stress testing capacities have been upgraded, although there is scope for improving the information base for financial stability 
analysis. The SARB should proactively use the scope allowed to it under Basel II to ensure adequate buffers at banks to manage the risks associated with lending to very highlyleveraged borrowers. The regulatory regime for insurance is also well-developed, although some gaps remain, such as on the supervision of groups. Effective supervision of the pension system, however, is complicated by the large number of pension funds. The authorities should encourage consolidation of these funds and strengthening of their governance and risk management in the pension fund industry.

The extensive interlinkages in the financial sector make supervisory cooperation critical. The system is dominated by a number of financial conglomerates, underscoring the need for regulators to ensure that supervision is both strong at the sectorial level and addresses risks that span more than one sector. Existing efforts toward greater cooperation, consistency, and effectiveness of regulation are welcome, although there remains a need to further strengthen information exchange, identify gaps and overlaps, and establish clear-cut delineations of responsibility among regulators.

The FSB has acted to curb abuses in the contractual savings segment and has brought several successful misconduct cases relating to trading on the Johannesburg Stock Exchange (JSE). Efforts should continue to increase disclosure and transparency in the markets and toward stronger market conduct regulation and supervision beyond the limited scope of the National Credit Act (NCA) and the Financial Advisory and Intermediary Services Act (FAIS).

Access to financial services has improved markedly in recent years. Through a combination of market-friendly interventions by the public and private sectors, the "banked" population in South Africa has grown from about 25 percent in 1994 to 63 percent today. The Financial Sector Charter (FSC) has been instrumental in broadening access and could provide further impetus for extending the reach of the financial system through appropriately revised objectives. The adoption of the NCA has also reined in reckless lending practices and improved consumer protection. Remaining challenges include: (i) bringing nonsalaried individuals into the system; (ii) broadening access to nonbank services; and (iii) financing small-and medium-sized enterprises (SMEs) and affordable housing. 


\section{Box 1. Main Recommendations ${ }^{1}$}

\section{Financial stability}

- $\quad$ Closely monitor emerging risks and conduct early warning analysis. Enhanced focus on banking system risks, including household credit and bank liquidity and funding risks, should be a priority. Proactively use the scope available under Basel II to ensure adequate buffers in banks to cope with risks associated with lending to highly leveraged borrowers, including for residential mortgages.

- $\quad$ Undertake a crisis simulation exercise to evaluate response capabilities to systemic stress in the financial sector. Further strengthen procedures for addressing banking problems and work towards the implementation of a well-designed deposit insurance system.

\section{Money, foreign exchange, and capital markets}

- $\quad$ Enhance surveillance of the OTC forex exchange derivative markets by systematic processing and analysis of information on offshore activity.

- $\quad$ Facilitate further development of the stock and bond markets, including by continued measured liberalization of exchange controls calibrated to take account of the macroeconomic situation.

\section{Financial sector supervision and regulation}

- $\quad$ Strengthen coordination and information exchange among regulators and policymakers. Minimize gaps and overlaps and clearly delineate responsibilities. The FSB should develop standards for corporate governance, risk management, and internal controls and harmonize its risk-based models for the different sectors.

- $\quad$ Enhance supervision of insurance groups and review adequacy of solvency buffers for life insurers ahead of the impending new international standards.

- $\quad$ Consider imposing fit and proper requirements for pension fund trustees and ensure that pension reform proposals preserve pension savings until retirement and that the drawdown of living annuities is appropriately aligned with life expectancy.

Financial sector inclusion and consumer protection

- $\quad$ Preserve the Financial Sector Charter and enhance its inclusion targets with due regard to financial soundness and stability.

- $\quad$ Review the mandates, products, and governance of development finance institutions (DFls) to maximize their catalytic role, and consider sound mechanisms for promoting affordable housing finance.

- $\quad$ Review the resources, staffing, and institutional arrangements of the NCR to ensure they are adequate.

\footnotetext{
${ }^{1}$ See Appendix IV for more detailed recommendations.
} 


\section{MACROECONOMic SETTING AND RISKS}

1. The pace of economic activity has started to ease following a period of robust expansion. Rising interest rates, domestic power supply constraints, and weaker global growth are beginning to dampen GDP growth and macroeconomic imbalances have begun to emerge. ${ }^{2}$ Inflationary pressures continue and consumer credit growth has yet to slow appreciably in response to higher interest rates. Household debt reached some 78 percent of disposable income in early-2008 and debt service costs have risen to 11 percent of disposable income, the highest level since 1998-99 (Appendix I, Figure 6).

2. The current account deficit widened to 9 percent of GDP in the first quarter of 2008 while portfolio inflows turned negative. Global financial market turbulence, concerns about the political transition, and the economic impact of power outages prompted a reversal in portfolio inflows in late-2007 and early-2008. While portfolio flows have recovered somewhat, the current account deficit is expected to remain at elevated levels as oil prices remain high and public enterprises push ahead with their investment plans. Spreads on South African debt widened relative to other emerging market debt and the rand fell by 11 percent in nominal effective terms over the first seven months of 2008, before recovering somewhat more recently.

3. The downside risks have increased as domestic growth prospects become more uncertain and investor sentiment remains fragile in the face of the current global market turmoil. With its large current account deficit and dependence on capital inflows, South Africa remains vulnerable to changes in investor sentiment and further deterioration in the global financial environment. The potential for stress arises across several fronts:

- Concerns about domestic growth prospects in conjunction with political and related policy uncertainties could lead to sustained drop in net capital inflows. This could trigger a sharp depreciation in the exchange rate, rising inflation, further monetary tightening, increasing debt servicing costs, and a sharp slowdown in consumption and investment.

- A sharp fall in commodity prices could threaten the prospects for the key resources sector and possibly also lead to portfolio equity outflows. In addition, a lower value of commodity exports would push the current account further into deficit.

- An intensification in the global slowdown could reduce demand for South African exports and dampen growth. South Africa also appears exposed to a weakening in growth in key emerging market economies, as that would in turn weaken commodity prices.

\footnotetext{
${ }^{2}$ For a detailed discussion of macroeconomic developments and outlook see Staff Report for the 2008 Article IV Consultation.
} 
- The risk of the household sector becoming overextended has increased as the economy moves late into the business cycle. Servicing historically high household debt may become too burdensome for many households. A sharp drop in housing prices, especially if accompanied by a deeper-than-expected economic slowdown and rising job losses, would aggravate these risks.

4. There are mitigating factors that should enable South Africa to cope with these risks. Good macroeconomic management has allowed the authorities to build buffers against external shocks. The public finances have strengthened significantly and the SARB is pursuing a strategy to further expand its international reserves cushion which had already been rebuilt to US\$35 billion by end-July. External debt is moderate at 26 percent of GDP and, with close to half of this denominated in rand, exposure to currency movements in the public and private sectors is limited. The flexible exchange rate regime should also continue to act as an important buffer in the face of external shocks.

\section{FINANCIAL INSTITUTIONS AND RISKS}

5. The generally favorable macroeconomic performance has underpinned the development of an advanced and diversified financial sector. The sector comprises a sophisticated banking sector, well-established capital markets, and an array of nonbank institutions, including insurance companies, pension funds, and collective investment schemes. The system is dominated by a few large conglomerates with interlocking ownership and operations covering a broad range of activities, including banking, insurance, brokerage, and asset management. The insurance and pension sectors are large and well-developed. Capital markets are relatively advanced with significant activity in the derivatives, securitization, and hedge fund markets. ${ }^{3}$

\section{A. Commercial Banks}

6. Commercial banks are the largest segment of the financial sector, with assets representing some 120 percent of GDP. Four banks - the Amalgamated Bank of South Africa (ABSA), FirstRand Bank, Nedbank, and Standard Bank-account for almost 85 percent of total assets and have substantial international presence. ${ }^{4}$ Beyond a strong position in domestic markets, South African banks' rapid expansion into African markets has been profitable and has contributed to their diversification. South African banks represent

\footnotetext{
${ }^{3}$ Securitization operations - 60 percent of which is linked to residential property—started in 2002 and took off in 2006, but still represent a limited share of banks' balance sheets.

${ }^{4}$ The high concentration of the banking sector has led to public debates about potential lack of competition and the cost of retail banking services. In response to concerns raised by consumers, small banks and nonbank stakeholders, in June 2008 an enquiry panel of the Competition Commission made recommendations covering: (i) penalty fees; (ii) ATM carriage fees; (iii) access to the national payment system; (iv) payment cards and interchange fees; and (v) products and pricing.
} 
substantial market shares in Botswana, Mozambique, Namibia, and Zimbabwe. ${ }^{5}$ At the same time, foreign presence in South Africa has increased significantly with the takeover by Barclays as the main shareholder of the ABSA in 2005 and the Industrial and Commercial Bank of China's (ICBCs) acquisition of 20 percent stake in Standard Bank at the end of 2007.

7. The banking system has withstood well the recent global market turmoil and was not significantly exposed to subprime-related products in the United States. ${ }^{6}$ Market related losses have also been limited so far and banks have been able to secure funding without much difficulty, their liabilities being largely domestically-generated and randdenominated. Nevertheless, South African banks are exposed to significant liquidity risks associated with a heavy reliance on domestic wholesale corporate deposits which results in part from long-standing limitations on capital outflows of corporates and institutional investors.

\section{Some pressures on banks' balance sheets are emerging as a result of the} sustained increase in interest rates and the softening in property prices. While nonperforming loan (NPL) ratios appear relatively low with substantial provisioning (Appendix I Table 4), increases in policy rates since 2006 have led to increased NPL ratios and arrears on credit card debt (Figure 1). Property markets have softened since the beginning of 2008 following several years of significant property price inflation. Corporate credit, however, does not appear to have raised similar concerns as South African corporations tend to rely relatively less on debt financing (Appendix I, Table 5). ${ }^{7}$

\section{Stress tests}

9. Stress testing shows that the banking system is most exposed to credit risk and to a lesser extent to market risk, although capital levels remain close to regulatory requirements after sizable shocks (Appendix II). ${ }^{8}$ Banks tend to follow an "originate and hold" lending strategy focused on relationship banking and careful monitoring of credit risk.

\footnotetext{
${ }^{5}$ Despite their dominant role in a number of countries, South African banks' foreign activities on the continent represent a small share of their balance sheets.

${ }^{6}$ In particular, conduits for asset-backed commercial paper-which became problematic in mature markets at the end of 2007-are not permitted to invest outside of South Africa and, therefore, have no exposure to the U.S. sub-prime market.

${ }^{7}$ According to Merrill Lynch, while the average net debt/equity ratio in Europe is 45 percent and 32 percent in the U.S., the figure for South African companies is 7 percent.

${ }^{8}$ Since the implementation of Basel II in January 2008, the minimum capital requirement has been set at 9.75 percent, the level of capital in the system being currently three percentage points above that requirement. Under Basel I, capital adequacy ratios were required to be at a minimum of 10 percent.
} 
The larger banks have implemented the advanced internal ratings based (IRB) approach under Basel II, which has led them to develop sophisticated risk monitoring and modeling capabilities. Single factor stress tests indicate that banks are most exposed to credit risk stemming from the retail sector (Appendix II). The severe macroeconomic stress scenario also generates considerable strain on banks with substantial additional credit losses (Appendix II, Table 15), which would combine with market related losses should a sudden stop in capital inflows lead to a severe correction in equity and bond prices.

Figure 1. South Africa: Mortgage and Credit Card Debt Performance
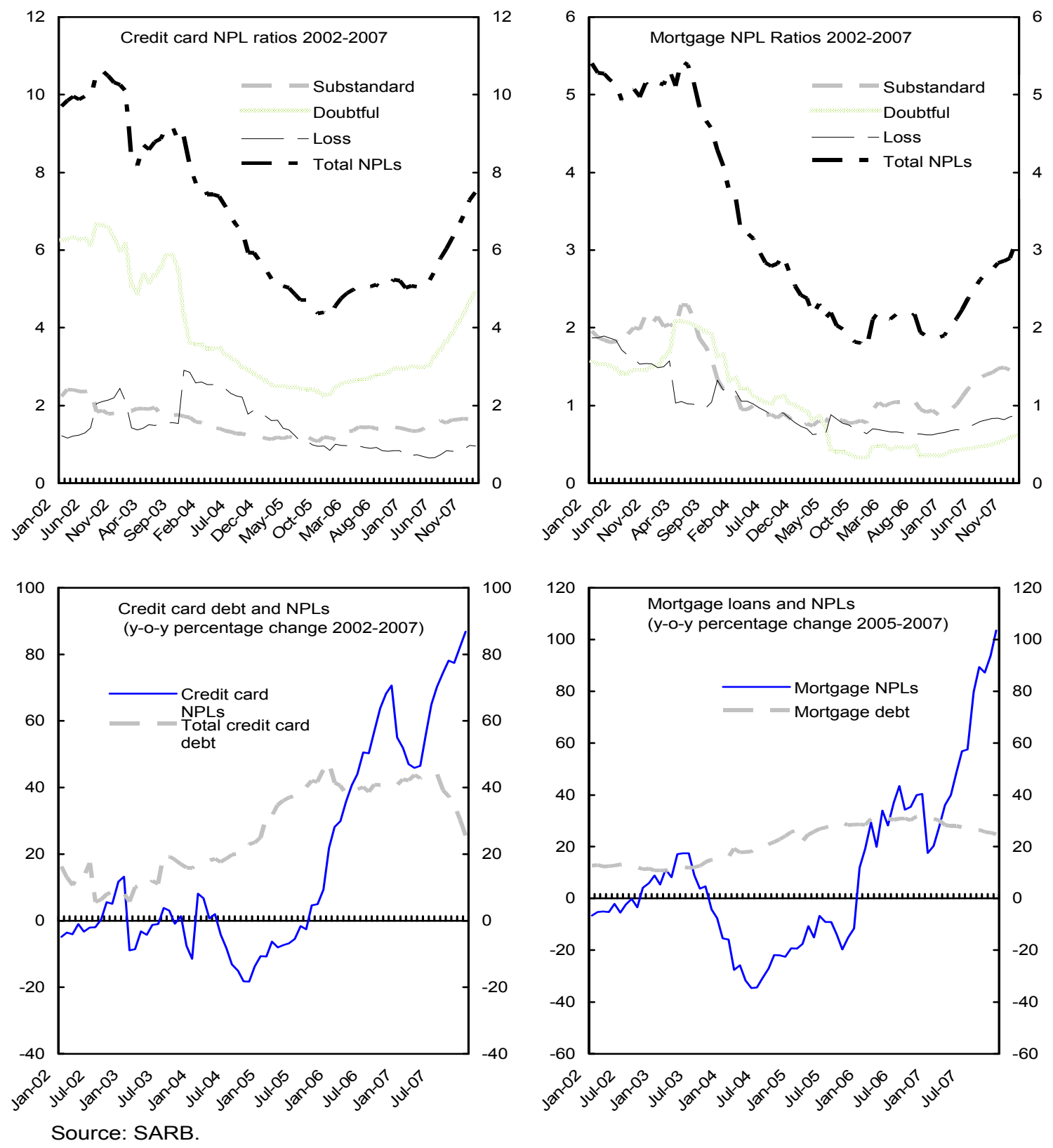
10. Stress tests also show that the vulnerability to market risks is generally moderate and the banking system as a whole has ample liquidity. Most banks tend to take only small active positions and hold substantial liquid assets. All major banks devote considerable resources to liquidity stress testing under different scenarios and have sophisticated liquidity management systems. However, the maturity of banks' funding is short and shortening further. A large portion of this is generated wholesale from domestic sources, including from life insurance companies and asset managers. Currently, banks have not experienced significant funding pressures beyond slightly firmer pricing and some shortening of maturity.

11. The stress testing analysis is subject to a number of caveats that are detailed in Appendix II. In particular, key parameter estimates are based on limited data that may not reflect structural changes and current and future conditions. Also, profits and balance sheet adjustments, which could provide some buffer, are not taken into account in the analysis. The risk management processes of the banks seem robust enough to suggest that prompt adjustments through management action would be possible.

\section{The SARB has strengthened its stress testing and model validation capacity} under the impetus of Basel II. However, off-site stress testing should become an integral part of analysis at the SARB, which should include analysis of individual bank data for the major banks. This should result in a more robust financial stability analysis, since systemic stress testing on aggregate data can mask wide variations across institutions. The SARB might also consider working with the FSB to integrate insurance sector stress tests in financial stability analysis.

\section{B. The Insurance Sector}

13. Insurance companies are major players in the South African financial sector. Life company assets were around 80 percent of GDP at end-2007. Insurance penetrationpremiums in relation to GDP - is among the highest globally at 16 percent of GDP. A key reason for the scale and significance of the life insurance sector is its large share of the retirement savings market. Nearly 50 percent of long-term insurers' balance sheets are accounted for by underwriting of retirement funds.

\section{Recent insurance sector performance has been strong, reflecting the buoyant} economy and strong equity-market growth. Insurers, both life and general, maintain large and growing surpluses in excess of regulatory minima and there have been no significant insurer failures in recent years. A large and increasing share of the investment risks in the asset portfolios of insurance companies is directly borne by policy holders in their shares of investment and bonus reserves. The sector has also benefited from long-run, riskmanagement initiatives to address the particular challenges of HIV/AIDS and high levels of crime. General insurers have been benefiting from a prolonged upswing in the underwriting cycle with a low incidence of major losses. 
15. The outlook for insurers, however, is less sanguine. For life insurers, high interest rates, rising inflation, and prospects for economic downturn have begun to result in higher policy lapses and surrenders. Insurers are seeing reductions in new business in some life products and in general insurance. They also face continued strong competition for savings business from mutual funds. There are increases in cost and operational pressures resulting from a scarcity of some essential technical skills. In the medium term, insurers face other significant challenges to their business model. They face increased pressure to improve standards of market conduct and regulatory scrutiny following specific problems in contractual savings - including high early termination penalties. The government's planned retirement and social security reforms, depending on their final shape, could lead to a drain of both retirement savings and protection business in favor of mandatory contributions to state insurance funds.

\section{Stress tests and risk management}

16. Stress tests indicate that, while life insurance companies are generally resilient to shocks, they are exposed to interest rate and equity price movements and unexpected increases in mortality or longevity (Appendix II, Table 10 and Figure 12). Investment and bonus reserves, which have grown strongly during recent bull markets, cushion the impact of the shocks to a large extent, but, in several cases, the effect would diminish the regulatory solvency buffer. Buffers would, nevertheless, stay above the minimum capital requirement in all but one case.

17. Insurance company risk management practices are improving. Life companies are now appropriately valuing the market risks related to guarantees in legacy and other business, and taking a more strategic approach to their management. At the same time, there are risks that remain hard to manage, particularly on annuities, where longevity risk cannot easily be hedged and matching liabilities with appropriate assets can be difficult in a market short of longer-term bonds. There are also potential contagion risks related to the interrelationships between insurance and banking, since four of the five largest insurance groups have ownership links to major banks.

\section{Pension Funds}

18. There is a large and highly developed pension and provident fund sector. Most employees in the formal sector are covered by occupational retirement fund arrangements, with the system considered to be "quasi-mandatory." Voluntary retirement savings, supported by tax incentives, are largely limited to middle and upper income workers and cover about 60 percent of workers in the formal sector. There were over 13,000 funds in 2005 with total assets in 2008 exceeding ZAR 2 trillion.

19. Certain elements of the retirement fund industry have attracted adverse publicity regarding equity and fair treatment of consumers. The public scrutiny has underscored substantial weaknesses in disclosure to trustees and customers and in meeting 
broader consumer-protection objectives. The recent strengthening of enforcement powers of the registrar of pensions is expected to improve the compliance culture in the industry. However, the limited understanding by many trustees of their fiduciary responsibilities remains a major problem. There is a need to develop a program of independent trustee training, either through an effective industry association or through accredited training institutions.

20. The current payout rules for retirement funds do not ensure lifetime income for retirees. The ability of members to draw down their retirement savings in as little as six years has recently been constrained by changes to the law and creation of industry codes, but more needs to be done to ensure that draw-downs of retirement balances are more closely aligned with life expectancy. The planned pension reform package should ensure that provident funds provide a form of lifetime income and move away from only lump-sum payments. The current reform proposals supporting the concept of "preservation" until retirement will be a major step forward.

\section{Financial Markets, Infrastructure, AND SAFETy NetS}

\section{A. Financial Markets}

\section{Equity and bond markets}

21. The performance of the JSE has been robust, albeit volatile, with net selling of industrial and financial shares by foreigners in recent months. The rise in the All-share Index (Figure 2) was supported primarily by gains in the commodity sectors (gold and platinum). Market capitalization of the JSE is the largest among emerging markets, reflecting South Africa's inclusion in major investable global stock market indexes. Nonresident sourced turnover accounts for some one-fifth of the total on the JSE. Stock market liquidity is more limited relative to other emerging markets, reflecting a few large listings and the buyto-hold strategy of domestic institutional investors. Index as well as single stock futures are traded on the JSE. The JSE also lists currency derivatives, settled in rand, which is attractive, in particular, to smaller enterprises.

\section{The Bond Exchange of South Africa (BESA) has seen an increase in}

capitalization and private issuance in recent years. Historically dominated by sovereign listings, the BESA provides price transparency to a thriving OTC bond market. At one-third of turnover, foreign participation is currently higher than on the JSE while foreigners have been net purchasers of bonds in recent months, partially offsetting the net selling of shares (Figure 3). The BESA also supports derivatives and, as a central source reporting trading information, provides transparency to OTC trade in repos, interest rate swaps (IRS) and forward rate agreements (FRA). 
Figure 2 South Africa: Market Indicators
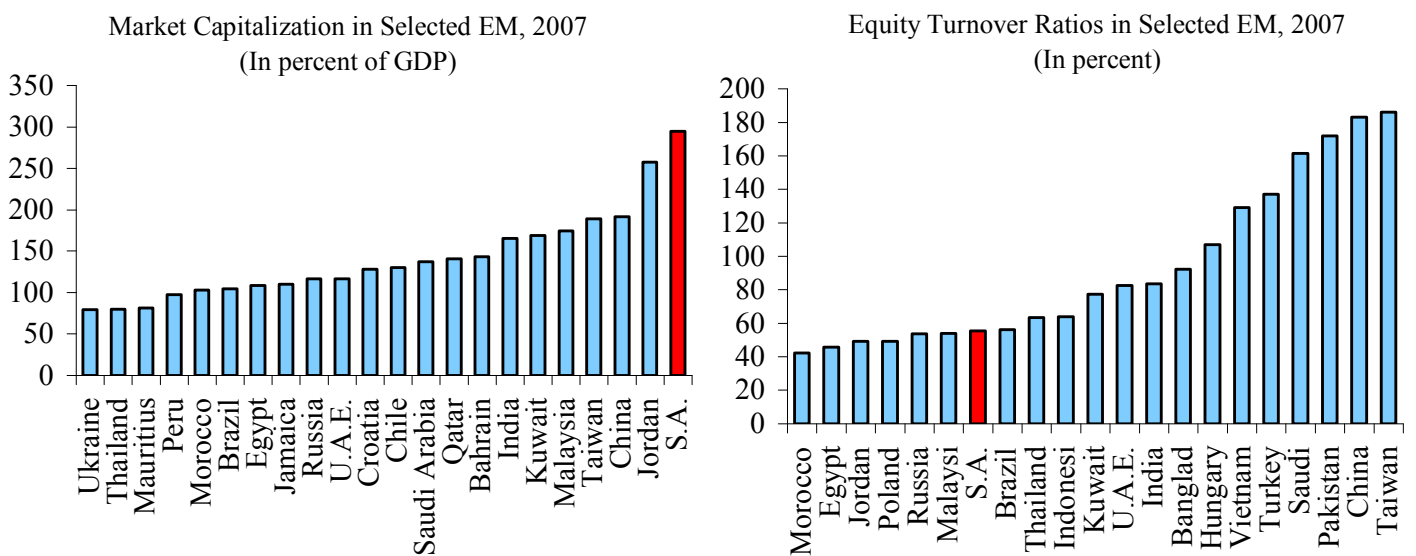

Net non-resident equities purchases

(In millions of ransd)

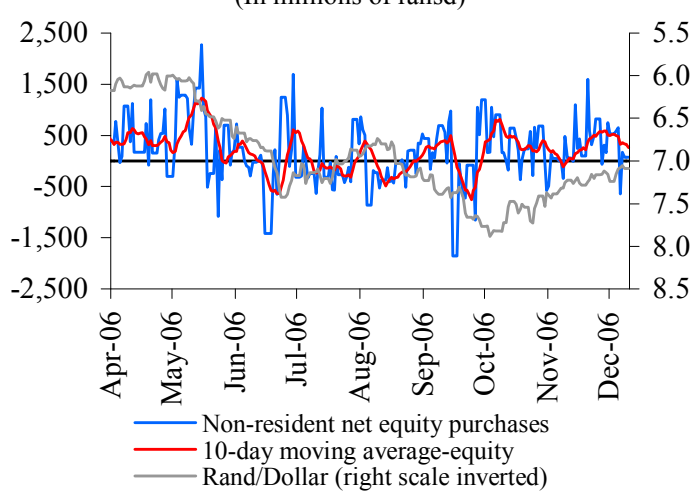

Dynamics of All-Stock Index
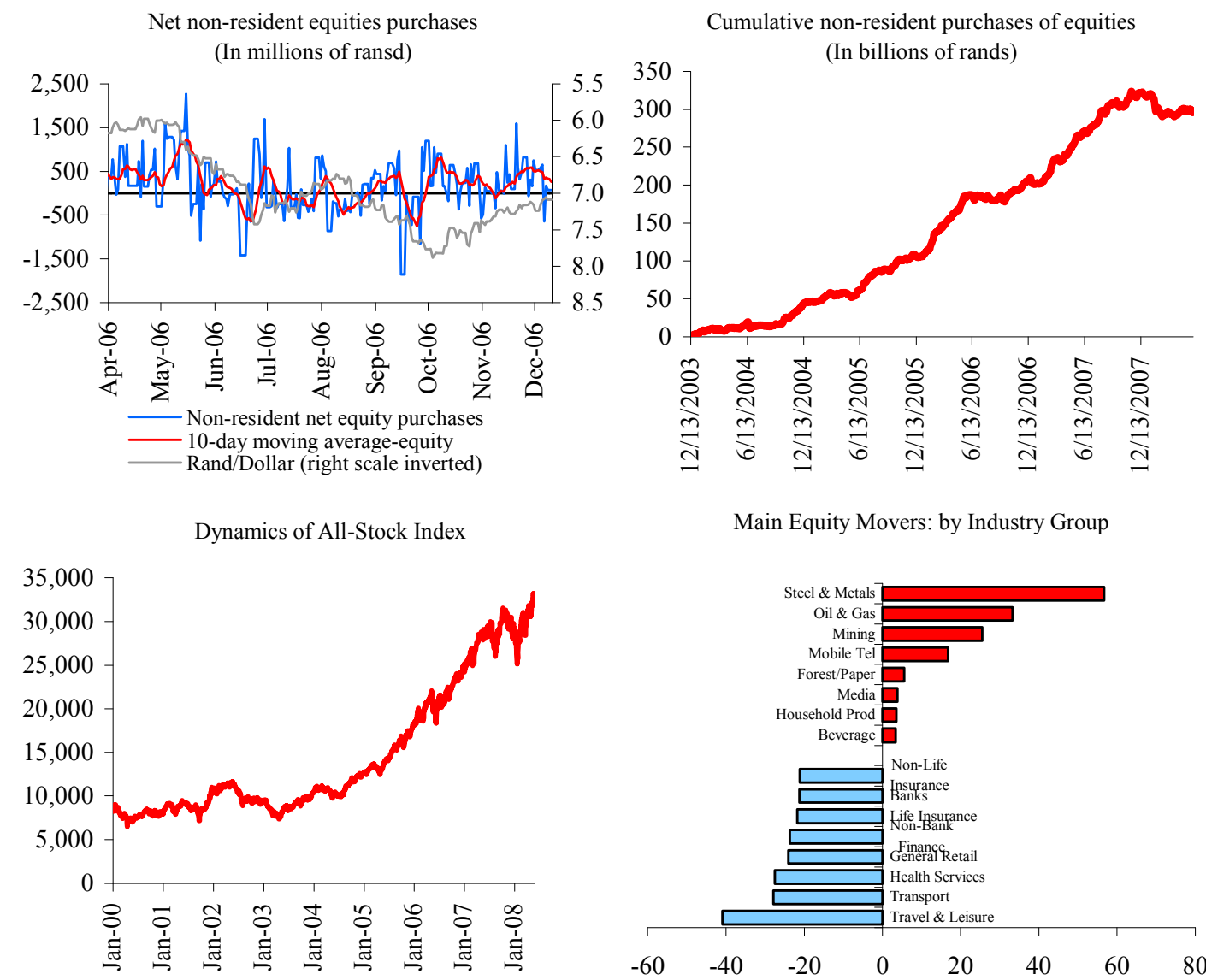

Main Equity Movers: by Industry Group

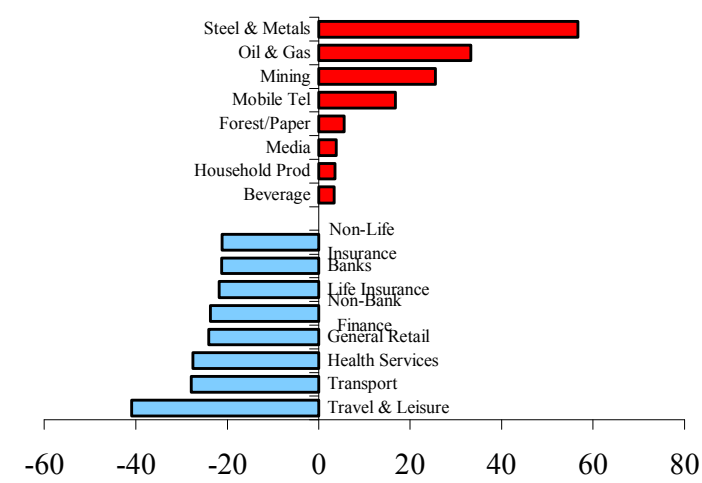

Source: IMF staff estimates based on EMDB, Bloomberg, and WEO.

Note: The turnover ratio is measured as the ratio of the value of share trading relative to domestic market capitalization. 
Figure 3. South Africa: Composition of Listing on the Bond Exchange of South Africa

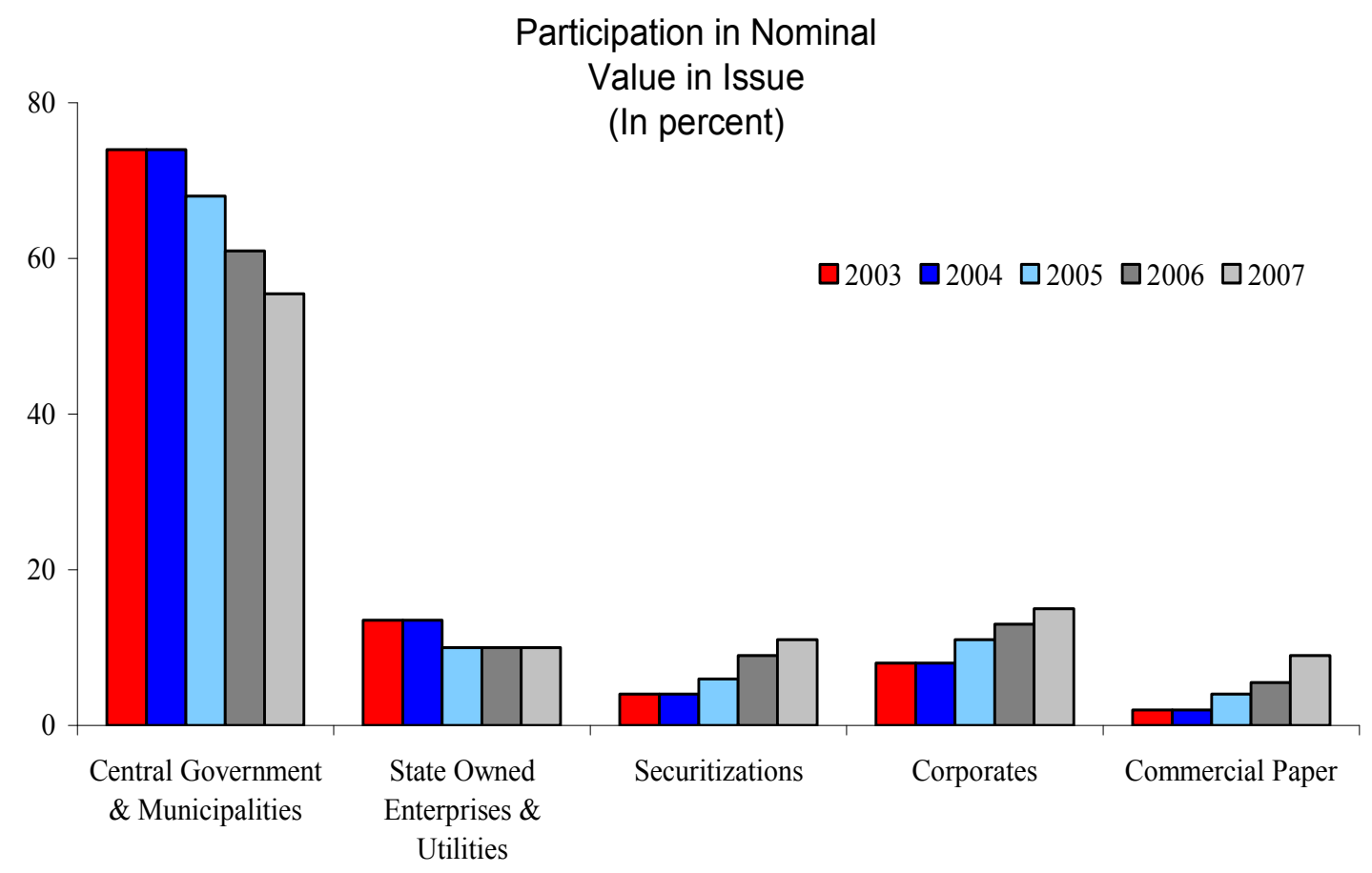

Annual Net Nonresident Equity and Bond Flows

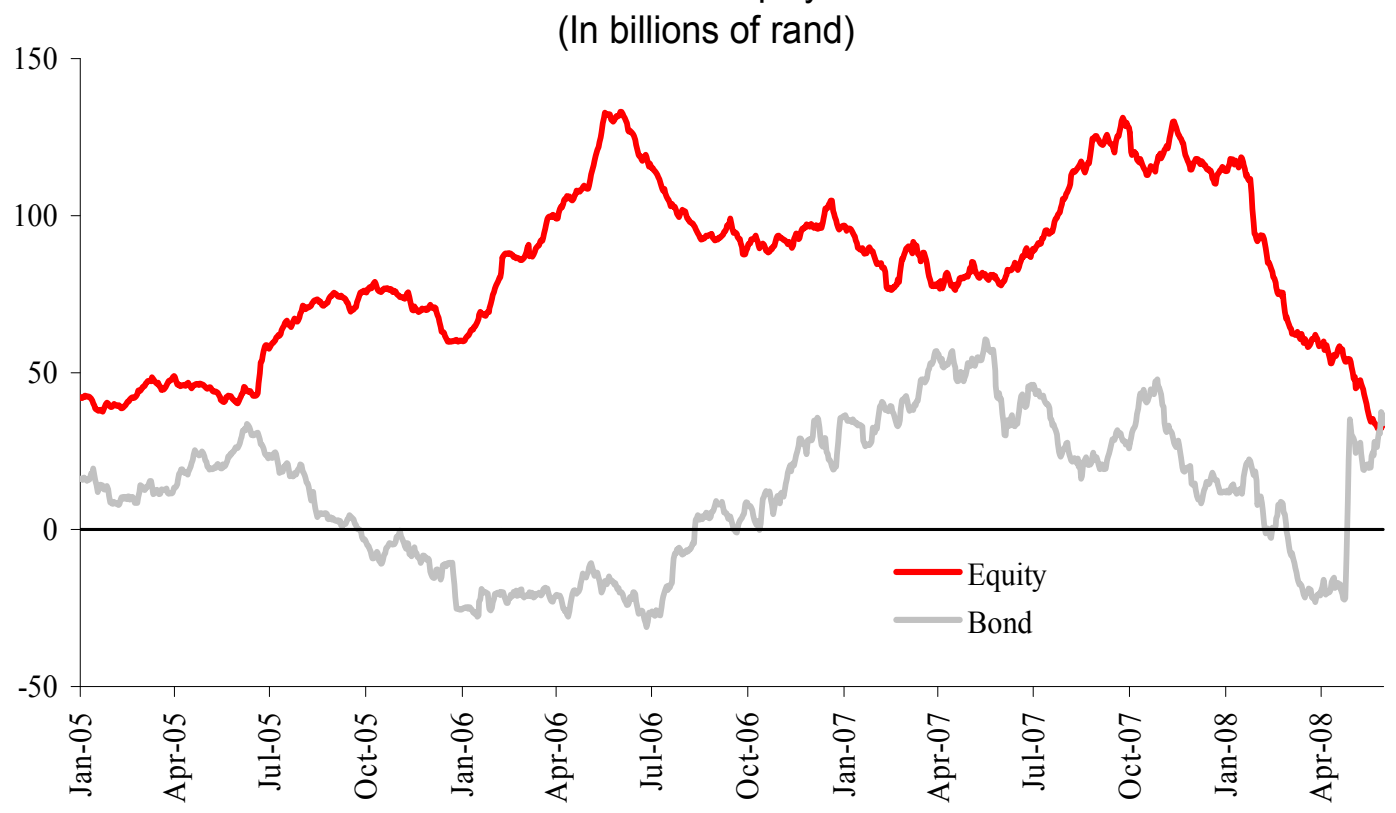

Source: IMF staff estimates based on Bloomberg. 


\section{The significant role of nonresident inflows in the stock and bond exchanges} underscores their susceptibility to changes in investor sentiment. This, in turn, places a premium on policies that support investor confidence and foster greater depth and liquidity of these markets. Further development of the stock and bond markets could also play a strategic role in financing South Africa's investment needs. Two areas in particular deserve attention: (i) further development of the bond market, e.g., for infrastructure financing; and (ii) efforts to increase stock market liquidity, such as by expanding the amount of shares available for trading on the stock market ("free float") within the policy of gradual relaxation of foreign investment limits for domestic institutional investors. ${ }^{9}$

\section{Money and foreign exchange markets}

24. Swap transactions dominate turnover in the foreign exchange market. Measured in terms of turnover to GDP, South Africa's foreign exchange derivatives market is the largest among the major emerging markets, reflecting the high turnover in foreign exchange swap transactions with a maturity of less than a week - over US\$9 billion daily as against less than US\$3 billion turnover in the spot market (Figure 4). The market is underpinned by short-term liquidity management by banks, whereby temporary surpluses of rands are swapped into dollars for a few days. The SARB occasionally also uses the swap instrument for draining liquidity. For longer maturities, banks rely on negotiable certificates of deposits, which are particularly liquid at three-month maturity. The Johannesburg Interbank Agreed Rate (JIBAR) is based on these instruments and is the benchmark for one of the most developed OTC derivative market among peer countries.

\section{Nonresident activity is very significant and a potential source of volatility in the} foreign exchange market. Transactions with nonresidents account for 71 percent of the turnover in the foreign exchange market, reflecting the participation of foreign banks. A majority of trades take place between desks in London and Johannesburg. High interest rates make offshore rand-denominated bonds attractive to retail investors in Europe and Japan for carry trade. The issuers typically take advantage of the liquid foreign exchange and derivative market to swap proceeds back into dollars. Hedging activity involving the rand is also affected occasionally by mergers and acquisition transactions either in South Africa or in neighboring countries. Should such activities typically involve sizeable transactions, they are likely to be accompanied by spikes in volatility on foreign exchange markets.

\footnotetext{
${ }^{9}$ Market participants underscored foreign investment limits on domestic institutional investors as an obstacle for large share-based foreign acquisitions of domestic companies.
} 
Figure 4. South Africa: Selected Countries: Size of Spot Foreign Exchange Markets and OTC Derivatives Average Daily Turnover in 2007

(In percent of GDP)

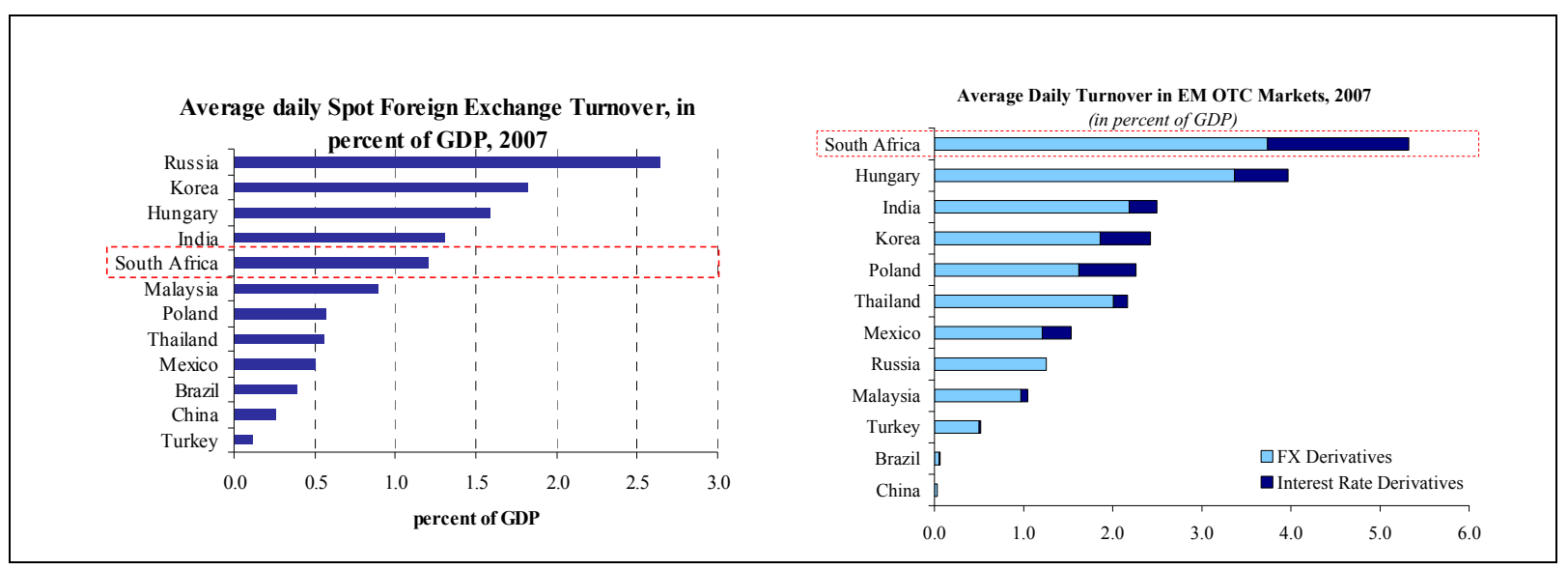

Source: BIS Triennial Central Bank Survey: December 2007.

26. Surveillance of the OTC foreign exchange derivative markets needs therefore to be enhanced. Trading between offshore dealers are not captured in official statistics and potential ensuing imbalances during settlement on the onshore spot market may go undetected. With most offshore dealers ultimately hedging their rand positions with South African counterparts, potential enhanced monitoring of hedging transactions based on the data already being collected on onshore transactions could provide useful information on the offshore market. ${ }^{10}$

\section{B. Systemic Liquidity Management}

\section{The global market turmoil did not pose any serious challenges for the}

management of domestic liquidity. Money markets were barely affected by the tightness in global markets and banks have built up adequate liquidity buffers. There has been no unusual recourse to SARB's standing facilities or repo operations and the money market showed no abnormal signs of strain (Appendix I Figure 7). Nonetheless, the close linkage of the domestic money market with the offshore rand and foreign exchange markets is a potential channel for contagion in times of stress.

\section{Maturities of money market instruments have tended to shorten in the wake of} rising domestic interest rates. This has also resulted in shorter maturities of wholesale

\footnotetext{
${ }^{10}$ For instance, an investor buying rands to invest into an offshore bond will ultimately purchase them from South Africa and these rands may find their way back via a swap.
} 
deposits in the banking system. The significant concentration of bank funding on the wholesale depositor base and the greater vulnerability of smaller banks could potentially engender broader liquidity pressures. The latter tend to rely heavily on refinancing facilities with larger banks. In light of these specific funding features, the authorities should work with banks to develop medium-term strategies to reduce their dependence on wholesale market funding.

\section{The SARB has introduced further flexibility in its instruments for regular} liquidity operations. To deal with the decreasing availability of short-dated government bonds, in May 2007, the SARB broadened its list of collateral for its refinancing operations, which now includes government securities, SARB debentures, Land Bank bills (category 1), and nongovernment bonds - mainly issued by parastatals excluding banks (category 2). For overnight liquidity needs, banks have daily access to standing facilities. ${ }^{11}$ In a situation of exceptional temporary liquidity shortage in an individual bank, the SARB can also temporarily waive cash reserve and liquid asset requirements. SARB's arsenal for addressing systemic liquidity problems is thus now more flexible.

\section{The systemic liquidity arrangements are supported by a robust and efficient} interbank payments system. At its core is the South African Multiple Option Settlement (SAMOS) where banks settle their obligations on a real-time basis. The SAMOS has been designed with a dynamic collateral facility and same day square off in compliance with the BIS Core Principles for Systemically Important Payment Systems. The system has been effective in providing early indications of impending counterparty payments problems but has also underscored the importance of proper coordination within the monetary operations framework.

\section{Exchange controls}

\section{The authorities are pursuing a strategy of gradual liberalization of exchange} controls which have been a key feature of South Africa's financial system. Since 1995, when most capital controls on nonresidents were eliminated, there has been a gradual liberalization of residents' foreign exchange transactions, although its pace has been constrained by the foreign exchange reserve position of the SARB. Quantitative limits on residents' - including institutional investors' investments abroad — have been increased in stages. In February 2008, significant further liberalization measures were announced. Consistent with the overall strategy of gradual capital account liberalization, the measures involved (i) raising limits on foreign exposure by institutional investors; (ii) simplifying the regulation of banks' foreign exposure; and (iii) streamlining the administration of foreign exchange controls. The changes are designed to shift from controls to a framework based on

\footnotetext{
${ }^{11}$ The standing facilities are available in the form of bilateral repo or reverse repo maturing the following day at a penalty rate of $50 \mathrm{bps}$ above the repo rate.
} 
prudential measures. The limit on banks' foreign exposure is to be raised to 40 percent of liabilities, although the definition and reporting of foreign exposures are still being worked out.

32. Further liberalization of the system would be challenging in light of the volatility in financial markets, heavy reliance on portfolio inflows, and corporate deposits in the banking system. Corporate rand deposits in banks equaled some 22 percent of GDP in March 2008. The National Treasury (NT) plans to undertake a study to assess the impact of the lifting of the remaining controls, especially on the funding of banks. The authorities should continue with their cautious approach to the liberalization of exchange controls, and prepare banks for the necessary diversification of their funding base. The success of their efforts would depend on: (i) appropriate timing to minimize the risk that the measures would need to be reversed; and (ii) proper reporting by commercial banks, securities dealers, and other market participants to enable the central bank to take corrective actions in a timely manner.

\section{Crisis Management and Safety Nets}

\section{The framework for domestic contingency planning has been strengthened.}

Channels of communication between the NT and the SARB for crisis prevention have widened, drawing on lessons from past crisis episodes, and now include regular bilateral meetings between the minister of finance (MOF) and the governor, and various subcommittees focusing on specific issues. In 2003, the Financial Sector Contingency Forum was created to coordinate preparedness for managing financial crises. ${ }^{12}$ The forum has led crisis exercises (involving simulated disaster), created a smaller incident-management team, and prepared a manual for a broad spectrum of crisis with particular emphasis on liquidity issues. More formal coordination arrangements involving memorandum of understandings (MOUs) and even legislation are being contemplated. Cross-border contingency planning is supported by regular exchanges between the Banking Supervision Department (BSD) and other supervisors.

\section{Effective lender-of -last-resort (LOLR) arrangements are in place but would be} strengthened by further refinements. The authorities' case-by-case approach to providing emergency liquidity support takes into account the potential for systemic threat and the solvency of the concerned institution (based on a solvency audit). The SARB can provide exceptional short-term liquidity assistance against pledged collateral or a government guarantee. For solvent banks, the SARB can provide such assistance in conjunction with other remedial measures. In the case of insolvent banks, although only the MOF (NT) has the

\footnotetext{
${ }^{12}$ Members of the Forum include the SARB, FSB, NT, the Banking Association of South Africa, the Life Offices Association, the South African Insurance Association, the JSE, BESA, the Payment Association of South Africa, the automated clearing house (Bankserv), and the central securities depository (Strate).
} 
power to appoint a curator, the course of action is decided in collaboration with the SARB. The NT is also likely to be involved in the event of liquidity problems at a solvent but systemically important institution. In the event of insolvency of such an institution, on a caseby-case basis, the NT can play a larger role and provide public funds as part of a resolution package. For systematically insignificant insolvent banks, the BSD can either approach the MOF to appoint a curator or apply to the courts for liquidation of the bank. A detailed operational framework for these situations is not formalized to retain flexibility.

\section{The emergency liquidity and bank resolution arrangements should be reviewed} with a view to further enhancing them. To identify weaknesses in the arrangements, the authorities should undertake a financial crisis simulation centered on the failure of a systemic institution. They should also consider formalizing the resolution process, possibly in a MOU, whereby the registrar of banks, who has extensive powers to safeguard the soundness of the banking system, is authorized to directly appoint a curator in order to prevent undue delays and thereby limit the potential for systemic contagion. ${ }^{13}$ The minister's intervention can be limited to only those cases requiring use of public funds. Financial sector participants also indicate that there is a need to specify the eligible collateral for LOLR operations in times of general distress in financial markets. The SARB is currently reviewing all its strategies regarding crisis management as part of the work of the FSCF in light of past crisis episodes experienced globally.

\section{The lack of deposit insurance is a conspicuous feature of South Africa's crisis} management and safety net arrangements. The process for launching a deposit insurance has been revived but faces a number of challenges. Discussions are focused on: (i) the composition of the Board of the South African Deposit Insurance Scheme (SADIS) and its degree of independence; (ii) the nature of the role of the agency in resolution matters; and (iii) the scale of initial government funding for the scheme. The related legislation is being redrafted and will be discussed with the SARB and presented to the Cabinet prior to release for public consultation. It would be important to ensure that the arrangements for deposit insurance adhere to sound principles, are designed primarily to protect small depositors in the banking sector, and avoid creating ambiguities in bank intervention powers.

\section{FinanCIAL SUPERVISION AND STANDARDS ASSESSMENTS}

\section{A. The Supervisory and Regulatory Framework}

\section{The institutional arrangements for financial supervision are captured in}

Figure 5. The two main statutory agencies are:

\footnotetext{
13 The appointment of a curator by the MOF requires the written consent of the chief executive officer or chairperson of the Board of the bank. This process could potentially delay such an appointment, or even make it problematic. International best practice allows for the supervisor to have the ability to act promptly in such circumstances.
} 
- The SARB - responsible for commercial bank regulation and supervision. The Banks Act and the Mutual Banks Act assign powers to the registrar of banks, an appointment made by the SARB subject to the approval of the MOF. The acts provide for the registrar to have a direct reporting line to the MOF. The BSD is funded from central bank resources and has around 100 staff.

- The FSB - responsible for insurance, pensions funds and intermediaries as well as oversight of capital markets. The FSB, which operates under various sectoral legislation, is governed by a Board of Directors which is accountable to government and parliament. The FSB is funded by fees paid by regulated entities and has 370 staff.

38. In addition, the National Credit Regulator (NCR), which operates under the National Credit Act, regulates the granting of consumer credit by all credit providers. The NCR is funded by the Department of Trade and Industry (DTI) and has a full time staff of 65. A number of self regulatory organizations (SROs) have responsibilities in capital and investment markets.

39. Prudential regulation has been strengthened in recent years, although there is scope for further development. Since the 2000 FSAP, the authorities have strengthened the framework and are largely compliant with international standards. ${ }^{14}$ In banking supervision, a major development has been the SARB's early implementation of Basel II. The FSB has also increased its resources, partly to meet new responsibilities but also to enhance its licensing, supervision and enforcement capabilities. South Africa was also an early adopter of IFRS and ISAS. $^{15}$

\section{The extensive interlinkages among the financial markets make supervisory} cooperation of particular importance. The financial system is dominated by a number of financial conglomerates with activities, often undertaken in separate legal entities, in several markets. There is thus a need for regulators to combine strong sectoral supervision, both prudential and market conduct, with a focus on identifying and managing risks that span more than one sector. In addition to strengthening communication and coordination between

\footnotetext{
${ }^{14}$ The FSAP assessment undertaken in 2000 found that the financial system and regulatory framework appeared robust, and transparency and supervisory practices were broadly in line with international standards. The principal recommendations included a call to expand onsite inspections of financial institutions, ensure that supervision and capital adequacy requirements took better account of cross shareholdings of financial conglomerates, and improve the procedures for resolution of problem banks. The authorities have addressed most of these issues and introduced new AML legislation.

${ }^{15}$ An Anti-Money Laundering and Combating the Financing of Terrorism (AML/CFT) assessment is being conducted by the Financial Action Task Force (FATF) and will be discussed at the FATF plenary meeting in February 2009 following which a ROSC will be circulated to the Executive Board for information.
} 
regulators, there is a need to identify gaps and overlaps and establish clear-cut delineations of responsibility. At present, a mechanism for resolving policy disagreements among different regulators and departments and assessing trade-offs among differing policy objectives is lacking. The Policy Board for Financial Services and Regulation was created to ensure better coordination, but it plays a purely advisory role to the NT.

Figure 5. South Africa: Regulatory and Supervisory Structure for the Financial Sector

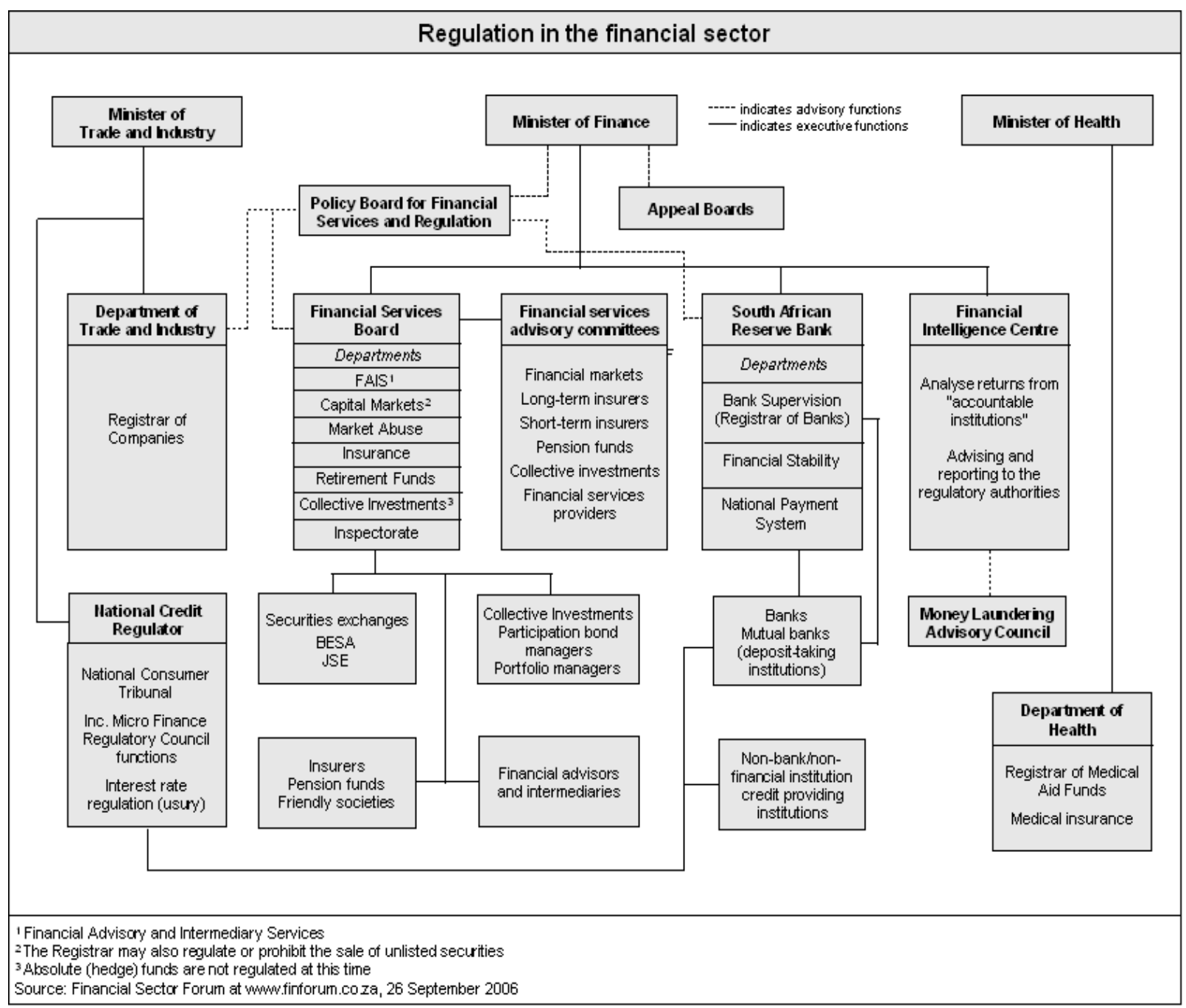

41. Future efforts could be focused on a number of areas:

- Greater day-to-day collaboration amongst the staff of the different sectoral regulators, in respect of individual institutions and emerging risk issues.

This would supplement the existing regular high-level meetings. There is also a need to enhance collaboration within the FSB, taking advantage of its wide span of responsibilities across savings and investment markets. This could help the 
FSB meet the challenge of improving market conduct in retail markets. In addition, NCR's market conduct responsibilities regarding household credit place a premium on regular coordination with sectoral regulators.

- An increased focus on qualitative standards, including corporate governance, risk management, and internal controls. Prudential regulation of a number of sectors - particularly insurance and pensions - could be strengthened by setting out clearly the regulator's expectations in these areas. This should allow some judgment on the part of firms on how to meet the standard, consistent with a move towards a more principles-based approach to supervision.

- Developing the skills of supervisors to meet the growing complexity of the regulatory requirements and the demands of taking a less compliance-based approach to supervision. While overall resources available to most of the regulators appear adequate, there is a need to enhance skills at the front line across all sectors.

- Improved allocation of resources in the further development of off-site risk assessment models. This could be achieved by taking a more consistent approach across sectors and increasing central capacity at the main regulators to identify risk and allocate resources flexibly to issues as they arise.

\section{B. Banking Supervision}

42. The regulatory framework for banks has been reinforced with the implementation of Basel II. Banks complied with the January 1, 2008 implementation deadline. The SARB has offered both the standardized and IRB approaches. Banks representing 80 percent of total assets are implementing the IRB approaches to credit risk, while one bank is also applying the advanced measurement approach for operational risk. In January 2008, South Africa participated in an IMF and World Bank pilot project on Basel II implementation. Subsequent implementation has proceeded well and Basel II has been largely capital-neutral for the four largest banks.

\section{The SARB is committed to meeting global best practice in its supervisory} regime. In addition to Basel II implementation, the BSD has addressed the recommendations of the 2000 FSAP report. Its self assessment of compliance with the October 2006 Basel Core Principles (BCP) identified few areas of noncompliance. It has reacted to emerging resource constraints through training programs, secondments and the use of outside experts, primarily auditors.

44. SARB's approach reflects the scale and significance of financial groups in the South African market. A comprehensive MOU between the BSD and the FSB governs overall arrangements for cooperation domestically, including regarding supervision of financial conglomerates. While collaboration between the parties has improved since the 
2000 FSAP, the BSD could focus on further development of its lead regulator role for relevant groups, drawing on its experience in the Basel II context.

45. The BSD is also seeking to enhance international coordination arrangements. It has entered into a number of MOUs with other supervisors and several others are pending. The BSD, as both home and host regulator, has actively engaged other supervisors, including in respect of acquisitions and Basel II. As is the case with all host supervisors, it is more exposed, especially in a crisis, to effective communication and cooperation by the respective home supervisors.

46. The SARB is focused on emerging vulnerabilities in the banking sector. The BSD has been monitoring, as appropriate, banks' risk estimates and the retail risk weights on a portfolio basis and stands ready to respond under the regulatory provisions of Basel II, should information indicate the need for supervisory intervention or action. Lending to new borrowers with a relatively short credit history should induce close vigilance and a forward looking approach, including proactive use of additional Pillar 2 add-ons. The authorities also recognize that lending is concentrated to a limited range of corporate clients reflecting the structure of the South African economy and large exposures policies are in place. The BSD has also been seeking to improve governance at the banks, for example by ensuring that banks' Boards have the appropriate skills and available time, including concerning prudential matters.

47. Supervisors need to enhance their focus on funding and liquidity issues. The banks do not appear to have comprehensive contingency plans in place should their access to domestic wholesale funding become restricted, say, for example, if the remaining exchange controls were lifted. Further analysis is warranted as part of a collaborative exercise between the SARB, the NT, and the FSB, possibly in the context of a Basel II Pillar 2 exercise and the planned study of the effects of an eventual lifting of remaining capital controls.

\section{Insurance}

48. The insurance regulatory regime is generally well-developed. The FSB has a modern solvency regime for life insurance and is in the process of introducing new riskbased requirements for general insurers with extensive quantitative and qualitative reporting. The FSB has an excellent process for reviewing returns and following up on issues, the results of which are integrated into a modern, though still evolving, risk-assessment framework, focused mainly on prudential issues but also including regular onsite work. Supervisors work closely with relevant overseas regulators.

49. There is a need to review the responsibilities of the NT and the FSB in insurance regulation. The NT is highly involved in regulatory policy in the consumer protection area. It is also responsible for steering draft regulations through the legislative process. Giving the FSB greater powers to set its own requirements would help ensure its operational independence from government. In the consumer protection area, the NT could look to the 
FSB to take a greater leadership role in policy formulation. This would help the FSB increase its focus on market conduct issues, where there is a large agenda, complementing its strong capabilities in the prudential arena.

50. There is also scope for the FSB to strengthen its approach in certain areas that will help address risks and vulnerabilities. These include: (i) enhanced supervision of groups; (ii) further guidance on governance, risk management, and internal controls; (iii) enhanced life insurance regulation, including review of the adequacy of solvency margins in preparation for the finalization of new international standards and better integration of stress testing into its reporting and supervisory regime; and (iv) greater effectiveness of its market conduct supervision.

\section{Pensions}

51. The large number of pension funds complicates the task of supervision and consolidation of the industry is being pursued by the FSB. Various factors are encouraging industry consolidation, including increased focus on the need for good governance, more intense supervision, rising costs, and potential benefits from economies of scale. Further measures could be taken to encourage consolidation, such as strengthening governance and risk management requirements and increased sensitization of trustees of their obligation to consider the impact of high cost structures on members' balances.

52. The governance framework for retirement funds needs to be strengthened. FSB's recently issued circular sets out in clear and concise terms the fiduciary responsibilities of trustees and suggests a range of good governance requirements. Consideration should be given to converting the circular into a regulation which can be enforced by the FSB. The FSB is also developing a risk-based supervisory model for retirement funds, the implementation of which is hampered by the lack of timely and accurate data reporting to the FSB.

53. Enforcement powers of the FSB have been strengthened considerably in the past year. Amendments to the law in September 2007 gave the FSB the power to impose penalties for noncompliance with the act, to remove trustees, and to perform on-site visits. Amendments before parliament will give the FSB extended enforcement powers. The FSB should consider introducing more specific fit-and-proper requirements supported by relevant training for those responsible for management and oversight of retirement funds (including trustees).

\section{E. IOSCO Assessment of Securities Markets}

54. The oversight and regulation of securities markets has been substantially strengthened (Annex I). Progress has been made in addressing the recommendations of the 2000 FSAP. FSB's legal authority has been greatly expanded through a series of new laws. The FSB has expanded its staff and onsite examination program for registered entities and 
SROs and has used its enforcement authority to address insider trading and market misconduct. Further progress could be made in certain areas of regulation, and the FSB should begin strategically assessing whether continued expansion of South African capital markets, including likely growth in the OTC market for specialized products, can be effectively regulated within the current structure.

\section{F. National Credit Regulator}

\section{The NCA and the NCR are bringing necessary and timely improvements to} consumer protection. The NCR is responsible for the regulation of all forms of household credit, extended by banks and nonbanks. Compliance with the NCA's prohibition on reckless lending required lenders to revamp underwriting and risk management procedures. The market conduct and disclosure requirements have increased transparency and laid the basis for greater competition among lenders. However, there may also be potential unintended negative consequences, and compliance with reckless lending provisions is yet to be tested in the courts.

56. The NCR is credited with having moved forcefully to investigate infractions but may lack resources to enforce the full range of NCA provisions. A key challenge is the requirement to build an effective, nationwide network of well-trained and registered debt counselors, as provided for in the law. The National Debt Mediators Association, an industry-led initiative, is developing a code for debt work-outs which could serve as a critical mechanism to resolve debt distress cases before they come to the counselors, magistrates, or tribunals. NCR's budget appears to be modest and subject to budgetary uncertainties relating to the DTI.

\section{FinANCIAL ACCESS AND INCLUSION ${ }^{16}$}

\section{A. Recent Performance and the Financial Sector Charter}

57. Financial inclusion is part of the transformation agenda in South Africa. The proportion of the population with access to a bank account has increased significantly in recent years - from 33 percent in 2005 to 45 percent in 2007 for the lower income brackets. The FSC, established in 2004, is viewed as an important catalyst for transformation. FSC's objectives include providing effective access to adequate financial services for all, improving racial representation in ownership, and fostering corporate governance that is representative of the community. ${ }^{17}$ However, the recent passage of the Broad-Based Black Economic

\footnotetext{
${ }^{16}$ These issues are covered in greater detail in the World Bank's Financial Sector Assessment.

${ }^{17}$ The FSC is "the negotiated outcome of a process whereby members of the financial sector, government, social partners and other stakeholders agreed to sector transformation through a formal course of action." (FSC Annual Review 2006).
} 
Empowerment Act has resulted in some uncertainty regarding the future of the FSC. Given its important role in promoting financial inclusion, it is highly desirable that the FSC be recognized under the act and that it maintains appropriate financial inclusion objectives.

58. Notwithstanding progress in financial inclusion, expanding access to reliable and affordable services remains a challenge. The key concerns are: (i) progress in access to bank accounts is characterized by a major divide between salaried and nonsalaried individuals; (ii) lending to SMEs remains limited; and (iii) other services beyond basic accounts lag far behind, notably savings and insurance products. As the FSC is being reviewed this year, there is an opportunity to further strengthen its targets.

\section{B. Housing Finance}

59. Mortgage markets have undergone impressive expansion. The FSC has been instrumental in promoting financing for affordable housing. The housing finance portfolio is concentrated in the four large banks and one nonbank home lender, South African Home Loans. As demand for housing has outstripped supply and prices have risen faster than incomes, access to financing for housing has increasingly become difficult for lower and middle income groups. FSC mortgages presently represent just 4.4 percent of banks' mortgage portfolios - only a fraction of the demand for new housing within stated income limits.

60. The government is currently considering consolidation of the three housing DFIs. The two small ones - the Rural Housing Finance Fund and the National Urban Residential Finance Corporation - appear to serve their respective market niches well. The National Housing Finance Corporation (NHFC) on the other hand, has not fulfilled its development mandate. An in-depth analysis of the needs regarding affordable housing finance is needed to help redefine the role of any newly configured housing DFI and to optimize its structure, products, corporate governance, funding, and incentives for partnership with the private sector. It would also be important to adjust the objectives of the FSC in housing finance and assess the extent of the need for any state support in this area. In addition, the effectiveness of the existing credit-linked subsidies and a new system of tax credits for developers in affordable housing should be carefully reviewed. 


\section{ANNEX I. ObSERVANCE OF FinANCIAL SECTOR STANDARDS AND CODES-SUMmary IOSCO ASSESSMENT}

\section{Introduction}

61. This is an Update of the IOSCO assessment that was performed in 2000 as part of the FSAP of South Africa. The FSAP Update was performed by Mr. Jonathan Katz, a technical consultant to the IMF/World Bank FSAP mission and formerly the Secretary of the U.S. Securities and Exchange Commission. Mr. Katz has performed six other IOSCO assessments or assessment updates.

\section{Information and methodology used for assessment}

62. The assessment was prepared on the basis of a self-assessment prepared by the FSB, public information contained on the FSB web site and the web sites of other entities in South Africa, and a review of relevant South African laws and regulations. The consultant interviewed numerous staff of the FSB, as well as other governmental officials, representatives of South African self-regulatory organizations and private sector professionals working in the capital markets in South Africa. These interviews were conducted over a two week period in May 2008. The consultant relied upon the IOSCO Assessment Methodology for guidance on the subjects to be examined for each principle.

\section{Institutional and market structure-overview}

63. The FSB was established in 1990 with the enactment of the Financial Services Board Act. The FSB is subject to the general authority of the MOF who appoints the members of the Board and selects the senior officers, after consultation with the Board. The responsibilities of the FSB are clearly articulated in the FSB Act and in a series of related laws that have expanded the duties and powers of the FSB.

64. The FSB has broad regulatory authority over the JSE Exchange and the BESA, financial advisors and intermediaries (FAIS), collective investment scheme operators (CIS), pension funds, and insurance companies. It has clear authority to perform on-site examinations, to require reports, and to investigate misconduct and to impose penalties for violations of applicable laws.

65. Other governmental agencies have responsibility for discrete regulatory functions that are included in the IOSCO principles. The DTI is responsible for the registration of all companies, including public companies listed for trading in the secondary market. Authority to enforce laws concerning mergers, acquisitions and changes in corporate control resides with the Securities Regulation Panel (SRP), an entity created by the Companies Act of 1973. As currently structured, the SRP is independent of the DTI.

66. The SARB, the nation's central bank, has certain relevant regulatory duties. While the FSB has responsibility for licensing bank subsidiaries engaged in brokerage or other nonbank 
financial services, the underwriting of securities typically is performed directly by the corporate finance department of a bank. As such, the SARB has regulatory responsibility for this function. Also, the SARB, through its foreign exchange control authority, has responsibility for approving cross-border dual listings and foreign securities offerings as part of its currency exchange control responsibilities.

67. The authority of the FSB has grown significantly since the 2000 FSAP. The Securities Services Act of 2004 expanded FSB's enforcement authority. The Collective Investment Schemes Control Act (CISCA) of 2002 and the Financial Advisory and Intermediary Services Act of 2002 expanded the authority of the FSB to register, regulate, and inspect asset managers, financial advisors (excluding stockbrokers and associated users already regulated by the JSE), and collective investment schemes. The Corporate Laws Amendment Act of 2007 addressed several recommendations of the 2002 Accounting and Auditing ROSC.

68. SROs are critical components of the regulatory system. The JSE Ltd is the primary and secondary market for listed equity securities, financial derivatives, agricultural commodities and a recently developed bond market. The BESA is the principal bond exchange. Both the JSE and the BESA operate as SROs and have primary regulatory responsibility for licensing members (authorized users) and employees and to enforce the exchange's listings requirements. Strate is an SRO that functions as the central securities depository for both listed equity securities and debt (government and corporate). Two clearing houses have been licensed by the FSB: Strate (for equities and bonds) and SAFCOM (for derivatives).

69. The JSE acts as the primary regulatory body for setting disclosure requirements for its public listed companies. While the DTI has broad legal authority in this area, traditionally it has focused its resources on the initial registration of all companies (public and private) and deferred to the JSE to regulate disclosure of its listed companies. As banks are the principal underwriter of securities in Africa, the SARB could also play a role in regulating this activity. It is estimated that over half of all public offerings are self-underwritten by the company issuing the securities, with marketing and distribution occurring by stockbrokers or financial intermediaries. The JSE requires listed companies to retain the services of a company sponsor (main board stocks) or a company advisor (Altx) who is responsible for conducting due diligence in the offering and ongoing advice to the company on regulatory responsibilities.

70. Regulation of CIS marketing and disclosure information to investors has been delegated by the FSB to the Association of Collective Investments (ACI), a voluntary industry organization that has declined to apply and be licensed as an SRO. As a condition of registration the FSB requires CIS registrants that are not members of the ACI to agree to be bound by ACI guidelines.

\section{Preconditions for effective securities regulation}

71. The South African capital markets have benefited from a strong legal infrastructure. It has a well-established judiciary that is perceived to be competent and independent. Its commercial laws and debtor-creditor laws are believed to be sound. South Africa was one of the 
first countries to adopt the International Financial Reporting Standards promulgated by the International Accounting Standards Board.

\section{Table 1. Summary Implementation of the IOSCO Principles}

\begin{tabular}{|c|c|}
\hline Principle & Findings \\
\hline $\begin{array}{l}\text { Principle 1. The responsibilities of the regulator should be } \\
\text { clearly and objectively stated. }\end{array}$ & $\begin{array}{l}\text { The South African system of financial services } \\
\text { regulation is complex, involving multiple } \\
\text { government agencies, several advisory or } \\
\text { oversight committees, and several self- } \\
\text { regulatory organizations. While all areas of } \\
\text { responsibility appear to be covered, there may } \\
\text { be gaps in the implementation of duties, which } \\
\text { will be discussed under the relevant substantive } \\
\text { principles. }\end{array}$ \\
\hline $\begin{array}{l}\text { Principle } 2 \text {. The regulator should be operationally } \\
\text { independent and accountable in the exercise of its functions } \\
\text { and powers. }\end{array}$ & $\begin{array}{l}\text { The FSB has full control over its budget and } \\
\text { daily operations. However the MOF has the } \\
\text { legal authority to block the promulgation of FSB } \\
\text { regulations and to fire Board members and FSB } \\
\text { senior staff. }\end{array}$ \\
\hline $\begin{array}{l}\text { Principle } 3 . \text { The regulator should have adequate powers, } \\
\text { proper resources and the capacity to perform its functions } \\
\text { and exercise its powers. }\end{array}$ & $\begin{array}{l}\text { Since the } 2000 \text { assessment the FSB has } \\
\text { obtained greatly expanded legal authority and } \\
\text { has succeeded in building its capacity to } \\
\text { exercise these responsibilities. The FSB lacks } \\
\text { regulatory authority over disclosure } \\
\text { requirements for public listed companies. }\end{array}$ \\
\hline $\begin{array}{l}\text { Principle } 4 . \text { The regulator should adopt clear and consistent } \\
\text { regulatory processes. }\end{array}$ & $\begin{array}{l}\text { The FSB has sound internal operating } \\
\text { processes. Its internal processes have received } \\
\text { ISO } 9000 \text { certification. }\end{array}$ \\
\hline $\begin{array}{l}\text { Principle } 5 \text {. The staff of the regulator should observe the } \\
\text { highest professional standards. }\end{array}$ & $\begin{array}{l}\text { The FSB has a Code of Conduct for its } \\
\text { employees that addresses confidentiality of } \\
\text { information, receipt of gifts from licensed } \\
\text { entities, and ownership of securities. }\end{array}$ \\
\hline $\begin{array}{l}\text { Principle } 6 \text { The regulatory regime should make appropriate } \\
\text { use of SROs that exercise some direct oversight } \\
\text { responsibility for their respective areas of competence and to } \\
\text { the extent appropriate to the size and complexity of the } \\
\text { markets. }\end{array}$ & $\begin{array}{l}\text { The JSE, BESA , and Strate perform several } \\
\text { core regulatory functions. The ACI has } \\
\text { delegated regulatory responsibilities but has } \\
\text { declined to become an SRO, subject to FSB's } \\
\text { oversight. }\end{array}$ \\
\hline $\begin{array}{l}\text { Principle } 7 . \text { SROs should be subject to the oversight of the } \\
\text { regulator and should observe standards of fairness and } \\
\text { confidentiality when exercising powers and delegated } \\
\text { responsibilities. }\end{array}$ & $\begin{array}{l}\text { The FSB has broad authority to license, subject } \\
\text { to annual renewal, its exchanges and SRO's. } \\
\text { Because the ACI has not registered and been } \\
\text { licensed as an SRO, the FSB lacks comparable } \\
\text { oversight authority, even though the ACl } \\
\text { performs functions comparable to those of an } \\
\text { SRO. }\end{array}$ \\
\hline
\end{tabular}




\begin{tabular}{|c|c|}
\hline Principle & Findings \\
\hline $\begin{array}{l}\text { Principle } 8 . \text { The regulator should have comprehensive } \\
\text { inspection, investigation, and surveillance powers. }\end{array}$ & $\begin{array}{l}\text { The FSB has strong inspection and } \\
\text { investigation powers and the JSE and the } \\
\text { BESA provide it with surveillance capacity over } \\
\text { listed markets. There is little surveillance } \\
\text { capacity over OTC activities. }\end{array}$ \\
\hline $\begin{array}{l}\text { Principle 9. The regulator should have comprehensive } \\
\text { enforcement powers. }\end{array}$ & $\begin{array}{l}\text { The FSB has expanded its ability to bring } \\
\text { enforcement actions administratively and is } \\
\text { seeking to expand this authority further. }\end{array}$ \\
\hline $\begin{array}{l}\text { Principle 10.The regulatory system should ensure an } \\
\text { effective and credible use of inspection, investigation, } \\
\text { surveillance, and enforcement powers and implementation of } \\
\text { an effective compliance program. }\end{array}$ & $\begin{array}{l}\text { A system, involving so many entities, creates } \\
\text { the potential for inconsistent or ineffective } \\
\text { regulation. Regulation of public company } \\
\text { disclosure by the DTI is an area of significant } \\
\text { concern. }\end{array}$ \\
\hline $\begin{array}{l}\text { Principle } 11 \text { The regulator should have the authority to share } \\
\text { both public and non-public information with domestic and } \\
\text { foreign counterparts. }\end{array}$ & $\begin{array}{l}\text { The FSB has full legal authority to share } \\
\text { information with domestic and foreign } \\
\text { regulators. }\end{array}$ \\
\hline $\begin{array}{l}\text { Principle 12. Regulators should establish information sharing } \\
\text { mechanisms that set out when and how they will share both } \\
\text { public and non-public information with their domestic and } \\
\text { foreign counterparts. }\end{array}$ & $\begin{array}{l}\text { The FSB has written agreements to share } \\
\text { information with the SARB and the revenue } \\
\text { authority. }\end{array}$ \\
\hline $\begin{array}{l}\text { Principle 13. The regulatory system should allow for } \\
\text { assistance to be provided to foreign regulators who need to } \\
\text { make inquiries in the discharge of their functions and } \\
\text { exercise of their powers. }\end{array}$ & $\begin{array}{l}\text { The FSB is a signatory to the IOSCO multi- } \\
\text { lateral MOU on information sharing. }\end{array}$ \\
\hline $\begin{array}{l}\text { Principle 14. There should be full, timely, and accurate } \\
\text { disclosure of financial results and other information that is } \\
\text { material to investors' decisions. }\end{array}$ & $\begin{array}{l}\text { Current disclosure standards provide investors } \\
\text { with necessary information on public } \\
\text { companies. Regulatory systems for proactively } \\
\text { reviewing periodic company disclosures could } \\
\text { be improved. Public disclosure of holdings by } \\
\text { company officers and large investors require } \\
\text { improvement. }\end{array}$ \\
\hline $\begin{array}{l}\text { Principle } 15 . \text { Holders of securities in a company should be } \\
\text { treated in a fair and equitable manner. }\end{array}$ & $\begin{array}{l}\text { The King Commission reports have contributed } \\
\text { to an improved system of corporate governance } \\
\text { and accountability. There is no effective method } \\
\text { to enable third parties to solicit voting proxies } \\
\text { from other shareholders. }\end{array}$ \\
\hline $\begin{array}{l}\text { Principle } 16 . \text { Accounting and auditing standards should be of } \\
\text { a high and internationally acceptable quality. }\end{array}$ & $\begin{array}{l}\text { South Africa was an early adopter of IFRS. } \\
\text { There is a national system for oversight of the } \\
\text { accounting and auditing profession. }\end{array}$ \\
\hline $\begin{array}{l}\text { Principle } 17 . \text { The regulatory system should set standards for } \\
\text { the eligibility and the regulation of those who wish to market } \\
\text { or operate a collective investment scheme. }\end{array}$ & $\begin{array}{l}\text { The CISCA and FAIS provide the FSB with } \\
\text { broad regulatory authority and the FSB has } \\
\text { successfully addressed its responsibilities. } \\
\text { Consideration should be given to issues raised } \\
\text { by white label funds and linked investment } \\
\text { service providers (LISPs). Legal gaps } \\
\text { complicate the development and regulation of } \\
\text { hedge funds. }\end{array}$ \\
\hline
\end{tabular}




\begin{tabular}{|c|c|}
\hline Principle & Findings \\
\hline $\begin{array}{l}\text { Principle 18. The regulatory system should provide for rules } \\
\text { governing the legal form and structure of collective } \\
\text { investment schemes and the segregation and protection of } \\
\text { client assets. }\end{array}$ & $\begin{array}{l}\text { The CISCA established a strong regulatory } \\
\text { framework for the CIS. The FSB has used its } \\
\text { licensing authority to address issues concerning } \\
\text { segregation of investor assets in LISPs. }\end{array}$ \\
\hline $\begin{array}{l}\text { Principle 19. Regulation should require disclosure, as set } \\
\text { forth under the principles for issuers, which is necessary to } \\
\text { evaluate the suitability of a collective investment scheme for } \\
\text { a particular investor and the value of the investor's interest in } \\
\text { the scheme. }\end{array}$ & $\begin{array}{l}\text { The FSB has delegated substantial } \\
\text { responsibility for setting and enforcing } \\
\text { disclosure standards for the CIS to the } \mathrm{ACl} \text {, a } \\
\text { non-SRO industry trade group. }\end{array}$ \\
\hline $\begin{array}{l}\text { Principle 20. Regulation should ensure that there is a proper } \\
\text { and disclosed basis for assets valuation and the pricing and } \\
\text { the redemption of units in a collective investment scheme. }\end{array}$ & $\begin{array}{l}\text { Regulation of CIS valuation and pricing is } \\
\text { sound. Development of comparable } \\
\text { requirements for LISPs should be a priority. }\end{array}$ \\
\hline $\begin{array}{l}\text { Principle 21. Regulation should provide for minimum entry } \\
\text { standards for market intermediaries. }\end{array}$ & $\begin{array}{l}\text { The FSB has developed a comprehensive } \\
\text { licensing system implementing its authority } \\
\text { under the FAIS and the CISCA. }\end{array}$ \\
\hline $\begin{array}{l}\text { Principle 22. There should be initial and ongoing capital and } \\
\text { other prudential requirements for market intermediaries that } \\
\text { reflect the risks that the intermediaries undertake. }\end{array}$ & $\begin{array}{l}\text { The JSE capital adequacy standards for its } \\
\text { licensed members appear to be sound and the } \\
\text { JSE BDA system provides daily information on } \\
\text { member firm open positions and exposure. } \\
\text { Comparable standards for licensees under the } \\
\text { FAIS have not been adopted by the FSB but } \\
\text { are under consideration. It should also assess } \\
\text { whether a general requirement of fiscal } \\
\text { solvency provides sufficient protection for } \\
\text { investors and for counterparties. }\end{array}$ \\
\hline $\begin{array}{l}\text { Principle 23. Market intermediaries should be required to } \\
\text { comply with standards for internal organization and } \\
\text { operational conduct that aim to protect the interests of } \\
\text { clients, ensure proper management of risk, and under which } \\
\text { management of the intermediary accepts primary } \\
\text { responsibility for these matters. }\end{array}$ & $\begin{array}{l}\text { The FSB requires licensees to have internal } \\
\text { control processes and internal compliance } \\
\text { officers. All client funds must be held in } \\
\text { segregated accounts and licensees must apply } \\
\text { "know your customer" principles in providing } \\
\text { financial advice. LISP regulation should be } \\
\text { reexamined. }\end{array}$ \\
\hline $\begin{array}{l}\text { Principle 24. There should be a procedure for dealing with } \\
\text { the failure of a market intermediary in order to minimize } \\
\text { damage and loss to investors and to contain systemic risk. }\end{array}$ & $\begin{array}{l}\text { The FSB and the JSE have authority to order } \\
\text { licensees to suspend or terminate operations } \\
\text { and the FSB may seek a court order to appoint } \\
\text { a conservator. }\end{array}$ \\
\hline $\begin{array}{l}\text { Principle } 25 \text {. The establishment of trading systems including } \\
\text { securities exchanges should be subject to regulatory } \\
\text { authorization and oversight. }\end{array}$ & $\begin{array}{l}\text { The JSE and the BESA must apply for annual } \\
\text { renewal of exchange licenses. The FSB } \\
\text { annually performs on-site examinations of both. }\end{array}$ \\
\hline $\begin{array}{l}\text { Principle 26. There should be ongoing regulatory supervision } \\
\text { of exchanges and trading systems, which should aim to } \\
\text { ensure that the integrity of trading is maintained through fair } \\
\text { and equitable rules that strike an appropriate balance } \\
\text { between the demands of different market participants. }\end{array}$ & $\begin{array}{l}\text { Ongoing market surveillance is performed by } \\
\text { the JSE and the BESA with FSB staff oversight } \\
\text { through weekly meetings and reports. }\end{array}$ \\
\hline $\begin{array}{l}\text { Principle } 27 \text {. Regulation should promote transparency of } \\
\text { trading. }\end{array}$ & $\begin{array}{l}\text { The systems in South Africa for trading in listed } \\
\text { securities are robust and comparable to } \\
\text { international best practices. The challenge } \\
\text { going forward will be to examine trading in the } \\
\text { OTC market. }\end{array}$ \\
\hline
\end{tabular}




\begin{tabular}{|l|l|}
\hline \multicolumn{1}{|c|}{ Principle } & \multicolumn{1}{c|}{ Findings } \\
\hline $\begin{array}{l}\text { Principle 28. Regulation should be designed to detect and } \\
\text { deter manipulation and other unfair trading practices. }\end{array}$ & $\begin{array}{l}\text { The JSE and the BESA have primary } \\
\text { responsibility for listed market surveillance. The } \\
\text { FSB has implemented its authority to enforce } \\
\text { laws prohibiting insider trading and market } \\
\text { manipulation. Consideration should be given to } \\
\text { the need for market surveillance in the OTC } \\
\text { market. }\end{array}$ \\
\hline $\begin{array}{l}\text { Principle 29. Regulation should aim to ensure the proper } \\
\text { management of large exposures, default risk and market } \\
\text { disruption. }\end{array}$ & $\begin{array}{l}\text { The JSE BDA system provides it with robust } \\
\text { data on member firm exposures. Both the JSE } \\
\text { and the FSB have the power to take action in } \\
\text { the event of a firm failure to avoid systemic } \\
\text { failures. }\end{array}$ \\
\hline $\begin{array}{l}\text { Principle 30. Systems for clearing and settlement of } \\
\text { securities transactions should be subject to regulatory } \\
\text { oversight, and designed to ensure that they are fair, effective } \\
\text { and efficient and that they reduce systemic risk. }\end{array}$ & $\begin{array}{l}\text { The JSE system for clearance and settlement } \\
\text { has a "zero failure" record. Nonetheless a } \\
\text { priority goal should be conversion to a T+3 } \\
\text { equity settlement cycle and legal action to } \\
\text { establish a central counterparty system. } \\
\text { Improvements in the trading infrastructure } \\
\text { should also include expansion of IT } \\
\text { telecommunications capacity for all trading. }\end{array}$ \\
\hline
\end{tabular}

Table 2. Recommended Action Plan to Improve Implementation of the IOSCO
Principles

\begin{tabular}{|l|l|}
\hline \multicolumn{1}{|c|}{ Principle } & \multicolumn{1}{|c|}{ Recommended Action } \\
\hline Principle 2 & $\begin{array}{l}\text { The FSB should have the authority to adopt and publish its } \\
\text { regulations without the approval of the MOF. The unlimited } \\
\text { discretion of the MOF to terminate senior FSB staff and } \\
\text { members of the FSB Board should be defined and limited to } \\
\text { circumstances where there is "good cause." }\end{array}$ \\
\hline Principle 5 & $\begin{array}{l}\text { The FSB should consider strengthening its rules for employees } \\
\text { to report securities trading, the receipt of gifts from the industry, } \\
\text { and negotiations for employment with regulated entities. }\end{array}$ \\
\hline Principle 6, 19 & $\begin{array}{l}\text { The status and delegated authority of the ACl should be } \\
\text { carefully reviewed in light of its substantial authority to set and } \\
\text { enforce regulatory standards for collective investment schemes. }\end{array}$ \\
\hline Principle 7 & $\begin{array}{l}\text { The FSB should obtain legal authority to formally review and } \\
\text { approve JSE listing standards. }\end{array}$ \\
\hline Principle 8 & $\begin{array}{l}\text { the FSB should carefully examine whether it should assume } \\
\text { greater responsibility in the OTC market. }\end{array}$ \\
\hline Principle 10 & $\begin{array}{l}\text { The ACl and the IRBA should publicly disclose disciplinary } \\
\text { actions information including the identity of the parties. Either } \\
\text { the ACl or the FSB should have the authority to impose } \\
\text { meaningful sanctions for violations of the CISCA. }\end{array}$ \\
\hline
\end{tabular}




\begin{tabular}{|c|c|}
\hline Principle & Recommended Action \\
\hline Principle 14 & $\begin{array}{l}\text { The FSB or the JSE should pro-actively monitor ongoing } \\
\text { periodic company disclosure reports. Public disclosure of } \\
\text { holdings by company officers and large investors require } \\
\text { improvement. }\end{array}$ \\
\hline Principle 15 & $\begin{array}{l}\text { Regulations providing an opportunity for third parties to solicit } \\
\text { voting proxies should be a priority. }\end{array}$ \\
\hline Principle 16 & $\begin{array}{l}\text { The IRBA should consider requiring public disclosure of notices } \\
\text { of accounting irregularities. }\end{array}$ \\
\hline Principle 17 & $\begin{array}{l}\text { The FSB should have broad legal authority to facilitate } \\
\text { development of an effective regulatory environment for hedge } \\
\text { funds. }\end{array}$ \\
\hline Principle 20, 22 & $\begin{array}{l}\text { Regulation of LISP disclosure and pricing publication practices } \\
\text { should be a priority. }\end{array}$ \\
\hline Principle 22 & $\begin{array}{l}\text { The FSB should consider the creation of a capital adequacy } \\
\text { requirement for non-JSE member intermediaries licensed under } \\
\text { the FAIS. It should also assess whether a general requirement } \\
\text { of fiscal solvency provides sufficient protection for investors and } \\
\text { for counterparties. }\end{array}$ \\
\hline Principle 29 & $\begin{array}{l}\text { The abolition of customer margin rules and the potential for } \\
\text { OTC derivative trading to affect exchange trading should be } \\
\text { examined. }\end{array}$ \\
\hline Principle 30 & $\begin{array}{l}\text { A priority goal should be conversion to a T+3 equity settlement } \\
\text { cycle and legal action to establish a central counterparty } \\
\text { system. Improvements in the trading infrastructure should also } \\
\text { include expansion of IT telecommunications capacity for all } \\
\text { trading. }\end{array}$ \\
\hline
\end{tabular}

\section{Authorities' response to the assessment}

72. The FSB provided detailed comments on each principle in the IOSCO assessment. The FSB disagreed with the following IOSCO assessment conclusions: 1) that the FSB should obtain the legal authority to proactively review listed company disclosure reports or the JSE should initiate such a program; 2) that the FSB should, in the future, consider the need for greater regulatory surveillance of the over the counter (OTC) market in South Africa,; and 3) that the lack of minimum customer margin requirements and concentration limits, combined with the lack of surveillance of OTC derivatives activities creates a counterparty risk exposure for JSE member firms that has systemic risk implications.

73. The FSB and the JSE believe that the current system, in which the JSE has authority to set disclosure standards for listed companies, and proactively reviews initial listing application disclosures and refers complaints concerning periodic disclosure reports to an industry review panel is satisfactory. 
74. With regard to the OTC market, the FSB states: "it is our understanding that OTC trades are not regulated in most of the jurisdictions of our counterparts. Due to the wide variety of instruments being traded OTC in South Africa, it is practically not possible to regulate all OTC instruments."

75. Regarding concerns over counterparty risk the FSB by states: "The fact that we dropped the margin requirement on carry accounts does not mean that we have no regulation on the extension of credit. If the member has accounted for any credit granted in their capital adequacy computation and they have the capital to absorb a client default then we don't need to specify strict credit or collateral requirements. The limits on counterparty concentration are imposed by the member's available capital. The fact that there are no specific limits does not create any systemic risk concerns provided the member has sufficient capital."

76. The FSB is seeking additional legal authority to establish capital adequacy standards and related regulatory standards for Financial advisers and intermediaries

(FAIS). "Besides the introduction of capital requirements for certain categories of FAIS licensees that is currently receiving attention, the obligatory introduction of fidelity and professional indemnity cover for all FAIS licensees should be introduced during 2008. These measures will go far in further protection of client interests. 


\section{Appendix I. Selected Macroeconomic and Financial Indicators}

\section{Appendix Table 3. South Africa: Selected Economic and Financial Indicators, 2003-09}

Nominal GDP (2007): US\$282.6 billion

Population (2007): 47.9 million

GDP per capita (2007): US\$ 5,907

\begin{tabular}{|c|c|c|c|c|c|c|c|}
\hline & 2003 & 2004 & 2005 & 2006 & 2007 & $\begin{array}{l}2008 \\
\text { Proj. }\end{array}$ & $\begin{array}{l}2009 \\
\text { Proj. }\end{array}$ \\
\hline & \multicolumn{7}{|c|}{ (Annual percent change, unless otherwise indicated) } \\
\hline National income and prices & & & & & & & \\
\hline Real GDP & 3.1 & 4.9 & 5.0 & 5.4 & 5.1 & 3.8 & 3.7 \\
\hline Real GDP per capita & 2.1 & 3.8 & 4.0 & 4.3 & 4.1 & 2.8 & 2.7 \\
\hline Real domestic demand & 5.2 & 7.9 & 5.7 & 9.2 & 6.0 & 4.2 & 4.1 \\
\hline GDP deflator & 4.6 & 5.5 & 5.2 & 7.2 & 8.9 & 11.6 & 9.7 \\
\hline CPI (annual average) & 5.8 & 1.4 & 3.4 & 4.7 & 7.1 & 11.3 & 9.2 \\
\hline CPIX (end of period) ${ }^{1}$ & 4.0 & 4.3 & 4.0 & 5.0 & 8.6 & 11.6 & 8.1 \\
\hline \multicolumn{8}{|l|}{ Labor market } \\
\hline Unemployment rate (percent) & 28.0 & 26.2 & 26.7 & 25.5 & 23.0 & 22.9 & 22.9 \\
\hline Average remuneration (formal nonagricultural sector) & 8.4 & 9.1 & 7.1 & 7.5 & 6.7 & 11.2 & 11.2 \\
\hline Labor productivity (formal nonagricultural sector) & 5.0 & 2.7 & 3.9 & 2.7 & 2.5 & 2.7 & 2.8 \\
\hline Nominal unit labor costs (formal nonagricultural sector) & 3.2 & 6.2 & 3.2 & 4.7 & 4.0 & 8.2 & 8.1 \\
\hline \multicolumn{8}{|l|}{ External sector } \\
\hline Merchandise exports, f.o.b. ${ }^{2}$ & 21.6 & 25.0 & 15.0 & 16.0 & 18.3 & 20.5 & 5.0 \\
\hline Merchandise imports, f.o.b. ${ }^{2}$ & 30.1 & 38.1 & 16.6 & 25.0 & 15.9 & 28.3 & 8.0 \\
\hline Export (goods and services) volume & 0.1 & 2.9 & 8.0 & 5.6 & 8.3 & 3.5 & 5.0 \\
\hline Import (goods and services) volume & 8.1 & 14.5 & 10.3 & 18.8 & 10.4 & 4.9 & 5.8 \\
\hline Terms of trade & 3.8 & 0.8 & 0.6 & 4.3 & 3.3 & -2.2 & -1.6 \\
\hline Nominal effective exchange rate (period average) ${ }^{3}$ & 25.1 & 9.1 & 1.1 & -5.6 & -9.7 & -16.3 & $\ldots$ \\
\hline Real effective exchange rate (period average) ${ }^{3}$ & 25.1 & 6.7 & 0.5 & -2.5 & -3.4 & -12.7 & $\cdots$ \\
\hline \multicolumn{8}{|l|}{ Money and credit } \\
\hline Net domestic assets ${ }^{4}$ & 7.2 & 11.3 & 14.6 & 15.4 & 21.4 & 21.9 & 19.0 \\
\hline Broad money (including foreign exchange deposits) & 12.9 & 13.1 & 20.5 & 22.5 & 23.6 & 26.3 & 20.8 \\
\hline Velocity (GDP/average broad money) & 1.6 & 1.6 & 1.5 & 1.4 & 1.3 & 1.2 & 1.1 \\
\hline Bank rate/repurchase rate (end of period, percent) ${ }^{5}$ & 8.0 & 7.5 & 7.0 & 9.0 & 11.0 & 12.0 & $\ldots$ \\
\hline & \multicolumn{7}{|c|}{ (Percent of GDP, unless otherwise indicated) } \\
\hline Investment and saving & & & & & & & \\
\hline Investment (including inventories) & 16.9 & 17.7 & 18.1 & 20.4 & 21.4 & 22.4 & 23.1 \\
\hline Of which: public fixed investment (including public enterprises) & 4.4 & 4.3 & 4.3 & 4.9 & 5.5 & 5.8 & 6.7 \\
\hline private fixed investment & 11.5 & 11.9 & 12.5 & 13.7 & 15.1 & 15.9 & 16.0 \\
\hline Gross national saving & 15.8 & 14.5 & 14.0 & 14.0 & 14.1 & 13.4 & 13.4 \\
\hline Public (including public enterprises) & 1.8 & 1.5 & 3.1 & 3.8 & 4.4 & 4.0 & 4.1 \\
\hline Private & 14.0 & 12.9 & 11.0 & 10.1 & 9.8 & 9.4 & 9.4 \\
\hline \multicolumn{8}{|l|}{ National government budget ${ }^{6}$} \\
\hline Revenue, including grants & 23.2 & 24.1 & 25.6 & 26.5 & 27.1 & 27.0 & 26.8 \\
\hline Expenditure and net lending & 25.2 & 25.7 & 26.2 & 26.1 & 26.3 & 26.5 & 27.0 \\
\hline Overall balance & -2.0 & -1.6 & -0.6 & 0.4 & 0.9 & 0.5 & -0.2 \\
\hline National government debt & 37.3 & 36.4 & 35.3 & 33.1 & 28.6 & 25.6 & 22.8 \\
\hline Borrowing requirement of the nonfinancial public sector & 2.0 & 1.7 & -0.2 & -0.4 & -0.3 & 1.0 & 1.9 \\
\hline \multicolumn{8}{|l|}{ External sector } \\
\hline Current account balance & -1.1 & -3.2 & -4.0 & -6.5 & -7.3 & -9.0 & -9.6 \\
\hline Overall balance of payments & -0.4 & 2.7 & 2.2 & 1.7 & 2.4 & 1.2 & 0.9 \\
\hline Total external debt & 23.6 & 20.8 & 19.1 & 22.2 & 26.6 & 29.6 & 31.2 \\
\hline Gross reserves (SARB, billions of U.S. dollars) & 8.0 & 14.7 & 20.6 & 25.6 & 33.0 & 36.6 & 39.6 \\
\hline (months of next year's total imports) & 1.6 & 2.6 & 2.9 & 3.1 & 3.2 & 3.3 & 3.3 \\
\hline
\end{tabular}

Sources: South African Reserve Bank (SARB); IMF, International Financial Statistics; and Fund staff projections.

${ }^{1} \mathrm{CPIX}$ is the consumer price index (CPI) excluding the interest on mortgage loans. It is the targeted definition of inflation.

${ }^{2}$ In U.S. dollars; annual percent change.

${ }^{3}$ For 2008, April relative to December 2007.

${ }^{4}$ Contribution (in percentage points) to the growth of broad money.

${ }^{5}$ For 2008, as of July 31.

${ }^{6}$ Calendar-year figures, based on staff's fiscal and GDP projections for 2008 and 2009. 
Figure 6. South Africa: Selected Household Indicators
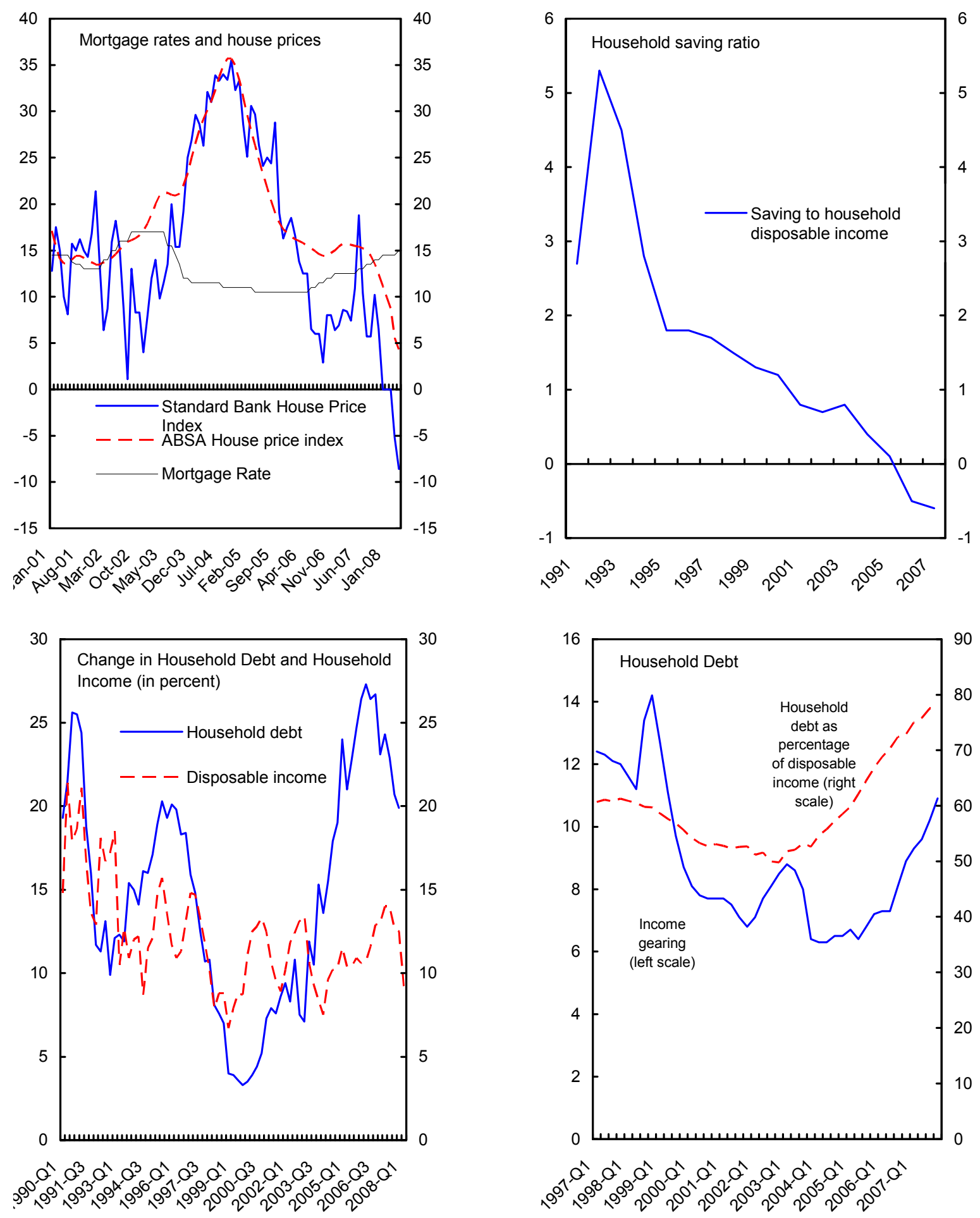

Source: SARB. 


\section{Appendix Table 4. South Africa: Financial Soundness Indicators, 2002-07}

\begin{tabular}{|c|c|c|c|c|c|c|}
\hline & 2002 & 2003 & 2004 & 2005 & 2006 & 2007 \\
\hline & \multicolumn{5}{|c|}{ (Percent, unless otherwise indicated) } & \\
\hline \multicolumn{7}{|l|}{ Capital adequacy: } \\
\hline Regulatory capital to risk-weighted assets ${ }^{1}$ & 12.6 & 12.4 & 14.0 & 12.7 & 12.3 & 12.8 \\
\hline Regulatory tier 1 capital to risk-weighted assets ${ }^{1}$ & 8.7 & 8.9 & 10.5 & 9.7 & 9.0 & 9.5 \\
\hline \multicolumn{7}{|l|}{ Asset quality: } \\
\hline Nonperforming loans to total gross loans ${ }^{2}$ & 2.9 & 2.4 & 1.8 & 1.5 & 1.1 & 1.4 \\
\hline Nonperforming loans net of provisions to capital ${ }^{2}$ & 13.2 & 8.5 & 6.2 & 6.4 & 5.6 & 8.2 \\
\hline Share of mortgage advances in domestic private credit $^{3}$ & 40.7 & 39.6 & 43.3 & 46.2 & 47.7 & 48.9 \\
\hline \multicolumn{7}{|l|}{ Earnings and profitability: } \\
\hline Return on assets (average) & 0.4 & 0.8 & 1.3 & 1.2 & 1.4 & 1.4 \\
\hline Return on equity (average) & 5.4 & 11.6 & 16.2 & 15.2 & 18.3 & 18.1 \\
\hline Interest margin to gross income & 52.3 & 38.3 & 41.6 & 38.2 & 43.8 & 58.5 \\
\hline Noninterest expenses to gross income & 60.4 & 74.8 & 68.5 & 61.5 & 48.5 & 48.9 \\
\hline \multicolumn{7}{|l|}{ Liquidity: } \\
\hline Liquid assets to total assets & 4.7 & 4.7 & 4.7 & 4.8 & 4.6 & 4.6 \\
\hline Share of short-term deposits in total deposits & 47.9 & 45.7 & 43.7 & 43.5 & 42.8 & 42.5 \\
\hline \multicolumn{7}{|l|}{ Exposure to FX risk: } \\
\hline Maximum effective net open FX position to capital & 3.6 & 1.3 & 0.8 & 1.9 & 1.4 & 0.7 \\
\hline Share of foreign currency loans in total lending & 13.6 & 11.9 & 10.9 & 11.1 & 11.4 & 9.3 \\
\hline Share of foreign currency deposits in total deposits ${ }^{4}$ & 4.4 & 2.7 & 2.7 & 2.7 & 3.3 & 3.0 \\
\hline Share of foreign liabilities in total liabilities ${ }^{5}$ & 6.3 & 3.8 & 4.0 & 4.2 & 5.3 & 6.0 \\
\hline \multicolumn{7}{|l|}{ Source: South African Reserve Bank. } \\
\hline \multicolumn{7}{|c|}{$\begin{array}{l}{ }^{1} \text { Total (banking and trading book). } \\
2 \text { The official definition of nonperforming loans comprises doubtful and loss loans. Doubtful are loans overdue for } 180 \text { days } \\
\text { unless well secured, or with a timely realization of the collateral. } \\
{ }^{3} \text { Domestic private credit not seasonally adjusted. } \\
{ }^{4} \text { Foreign funding to total funding. }\end{array}$} \\
\hline
\end{tabular}

\section{Appendix Table 5. South Africa: Selected Indicators for the Corporate Sector}

\begin{tabular}{lcccc}
\hline (Annual growth unless otherwise indicated) & 2005 & 2006 & \multicolumn{2}{c}{2007} \\
\cline { 3 - 5 } & Q4 & Q4 & Q2 & Q4 \\
\hline Credit to the corporate sector as percentage of GDP & 28.9 & 33.8 & 36.9 & 36.8 \\
Real Gross Fixed Capital Formation & 16.9 & 26.0 & 24.4 & 23.2 \\
Credit to the corporate sector & 19.7 & 32.1 & 31.3 & 25.3 \\
Credit to the corporate sector as percentage of annualized profits & 156.3 & 178.3 & 179.4 & 187.4 \\
Net operating surplus 1/ & 12.0 & 15.9 & 22.7 & 17.6 \\
& & & & \\
Memorandum items & & & & $\ldots$ \\
Debt to asset ratio (in percent) & 16.2 & 16.2 & $\ldots$ & $\ldots$ \\
Debt to asset ratio (in percent), average emerging economies & 20.4 & 20.4 & $\ldots$ & $\ldots$ \\
\hline
\end{tabular}

Sources: SARB and IMF Vulnerability Exercise.

$1 /$ Gross operating surplus minus depreciation. 
Appendix Table 6. South Africa: Pension Funds, Insurers, and Unit Trusts

\begin{tabular}{|l|rr|rr|rr|}
\hline & \multicolumn{2}{|c|}{$\begin{array}{c}\text { In billions of } \\
\text { rands }\end{array}$} & \multicolumn{2}{c|}{$\begin{array}{c}\text { In Percent of } \\
\text { Total }\end{array}$} & \multicolumn{2}{c|}{$\begin{array}{c}\text { In Percent of } \\
\text { GDP }\end{array}$} \\
\hline & 2000 & 2006 & 2000 & 2006 & 2000 & 2006 \\
Official Pension Funds & 252.0 & 691.0 & 18.2 & 23.4 & 27.3 & 40.0 \\
Self-Administered Private Pension Funds & 365.0 & 613.1 & 26.4 & 20.7 & 39.6 & 35.5 \\
Underwritten Private Pension Funds & 293.1 & 629.6 & 21.2 & 21.3 & 31.8 & 36.5 \\
Total Pension Funds & 910.1 & 1933.7 & 65.9 & 65.4 & 98.7 & 112.0 \\
& & & & & & \\
Long-Term Insurers (LTIs) & 707.0 & 1361.0 & 51.2 & 46.0 & 76.7 & 78.8 \\
Less Underwritten Pension Funds & 293.1 & 629.6 & 21.2 & 21.3 & 31.8 & 36.5 \\
Less Insurance Policies of SAPF & 106.1 & 171.9 & 7.7 & 5.8 & 11.5 & 10.0 \\
Net Assets of LTIs & 307.8 & 559.5 & 22.3 & 18.9 & 33.4 & 32.4 \\
& & & & & & \\
Total Pension Funds and LTIs & 1217.9 & 2493.2 & 88.2 & 84.4 & 132.1 & 144.4 \\
Short-Term Insurers & 47.7 & 67.4 & 3.5 & 2.3 & 5.2 & 3.9 \\
Unit Trusts & 115.4 & 395.1 & 8.4 & 13.4 & 12.5 & 22.9 \\
Grand Total & 1381.0 & 2955.7 & 100.0 & 100.0 & 149.8 & 171.1 \\
& & & & & & \\
GDP & 922 & 1727 & & & & \\
\hline
\end{tabular}

Source: SARB.

\section{Appendix Table 7. South Africa: Selected Indicators for the Insurance Sector, 2006-07}

\begin{tabular}{lrr}
\hline & Dec. 2006 & Dec. 2007 \\
\hline Free assets to capital adequacy requirement 1/ & & \\
Covered 0-1 times & 0 & 0 \\
Covered 1-2 times & 6 & 7 \\
Covered 2-5 times & 16 & 14 \\
Covered 5-10 times & 7 & 4 \\
Covered 10+ times & 2 & 1 \\
Total & 31 & 26 \\
Individual lapses 2/ & 38 & 44 \\
Individual surrenders 2/ & 22 & 16 \\
Number of policies (year on year percent change) & 4.0 & 7.0 \\
Share prices (year on year percent change) & 26.3 & 7.8 \\
\hline
\end{tabular}

Sources: Financial Services Board and South African Reserve Bank.

$1 /$ Number of insurers.

2/ Percentage of number of new policies issued. 


\section{Appendix Table 8. South Africa: Institutional Investors, Corporates, and Household Deposits}

(Rand deposits in commercial banks as of March 2008)

\begin{tabular}{|c|c|c|c|c|c|c|c|c|}
\hline & $\begin{array}{c}\text { Deposits: } \\
\text { Cheque }\end{array}$ & $\begin{array}{c}\text { Deposits : } \\
\text { Savings }\end{array}$ & $\begin{array}{l}\text { Deposits : } \\
\text { Other } \\
\text { demand - } \\
\text { Up to } 1 \text { day }\end{array}$ & $\begin{array}{l}\text { Deposits : } \\
\text { Other short- } \\
\text { term - More } \\
\text { than } 1 \text { day to } \\
1 \text { month }\end{array}$ & $\begin{array}{c}\text { Deposits : } \\
\text { Medium- } \\
\text { term - More } \\
\text { than } 1 \\
\text { month to } 6 \\
\text { months }\end{array}$ & $\begin{array}{l}\text { Deposits : } \\
\text { Long-term - } \\
\text { More than } 6 \\
\text { months }\end{array}$ & $\begin{array}{l}\text { Deposits : } \\
\text { TOTAL }\end{array}$ & $\begin{array}{c}\text { Of which } \\
\text { NCD's/PN's }\end{array}$ \\
\hline SA Banks & 1.6 & 0.0 & 10.4 & 4.1 & 4.0 & 13.4 & 6.6 & 7.0 \\
\hline Public financial corporate sector (such as IDC, DBSA) & 0.3 & 0.0 & 0.4 & 0.6 & 0.3 & 0.0 & 0.3 & 0.2 \\
\hline Public Investment Corporation (PIC) & 3.4 & 0.0 & 1.1 & 1.6 & 4.4 & 8.0 & 3.6 & 3.8 \\
\hline \multicolumn{9}{|l|}{ Public non-financial corporate sector (such as Transnet, } \\
\hline Eskom and Telkom) & 1.2 & 0.0 & 2.3 & 4.8 & 3.2 & 2.6 & 2.6 & 2.9 \\
\hline Insurers & 2.7 & 0.0 & 2.8 & 1.8 & 3.4 & 5.2 & 3.1 & 5.4 \\
\hline Pension funds & 1.9 & 0.0 & 1.7 & 1.3 & 1.7 & 4.7 & 2.2 & 2.6 \\
\hline Money-market unit trusts & 0.0 & 0.0 & 2.0 & 2.6 & 4.4 & 4.6 & 2.5 & 1.9 \\
\hline Non-money market unit trusts & 0.0 & 0.0 & 0.3 & 0.7 & 1.1 & 1.6 & 0.7 & 1.7 \\
\hline Fund-managers & 1.5 & 0.0 & 7.9 & 10.0 & 19.1 & 21.8 & 11.3 & 33.9 \\
\hline Other & 8.9 & 0.1 & 10.4 & 14.2 & 17.1 & 16.0 & 12.6 & 30.0 \\
\hline Private non-financial corporate sector & 35.6 & 8.2 & 34.1 & 25.2 & 11.9 & 8.4 & 22.8 & 6.0 \\
\hline Unincorporated business enterprises of households & 7.5 & 4.1 & 3.0 & 4.2 & 1.6 & 0.4 & 3.4 & 0.2 \\
\hline Households & 16.8 & 82.4 & 12.2 & 16.3 & 17.1 & 7.5 & 17.0 & 0.5 \\
\hline
\end{tabular}

\section{Source SARB}

Figure 7. South Africa: Money Market Rates

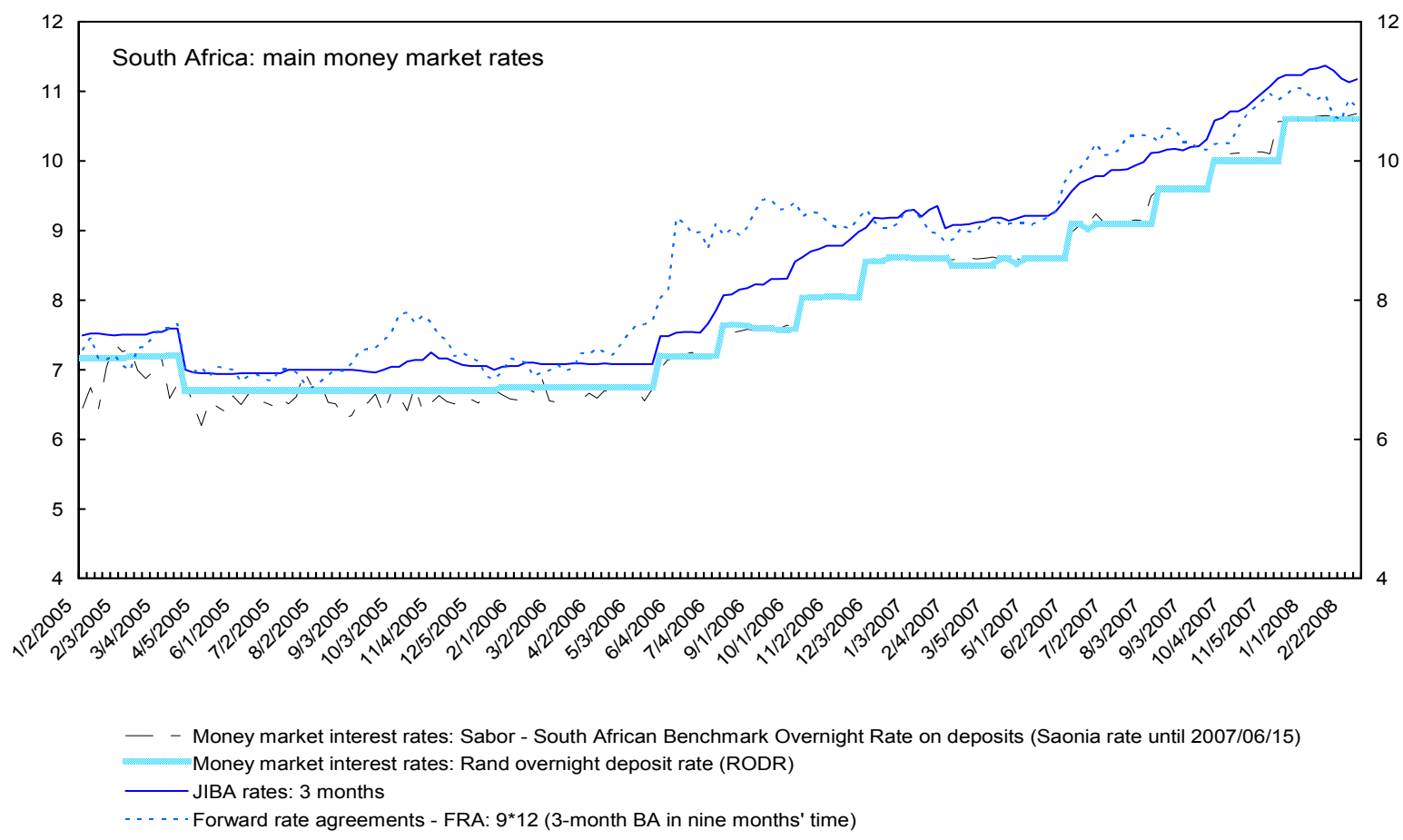

Source: SARB. 
Figure 8. South Africa: SARB Liquidity Draining Operations

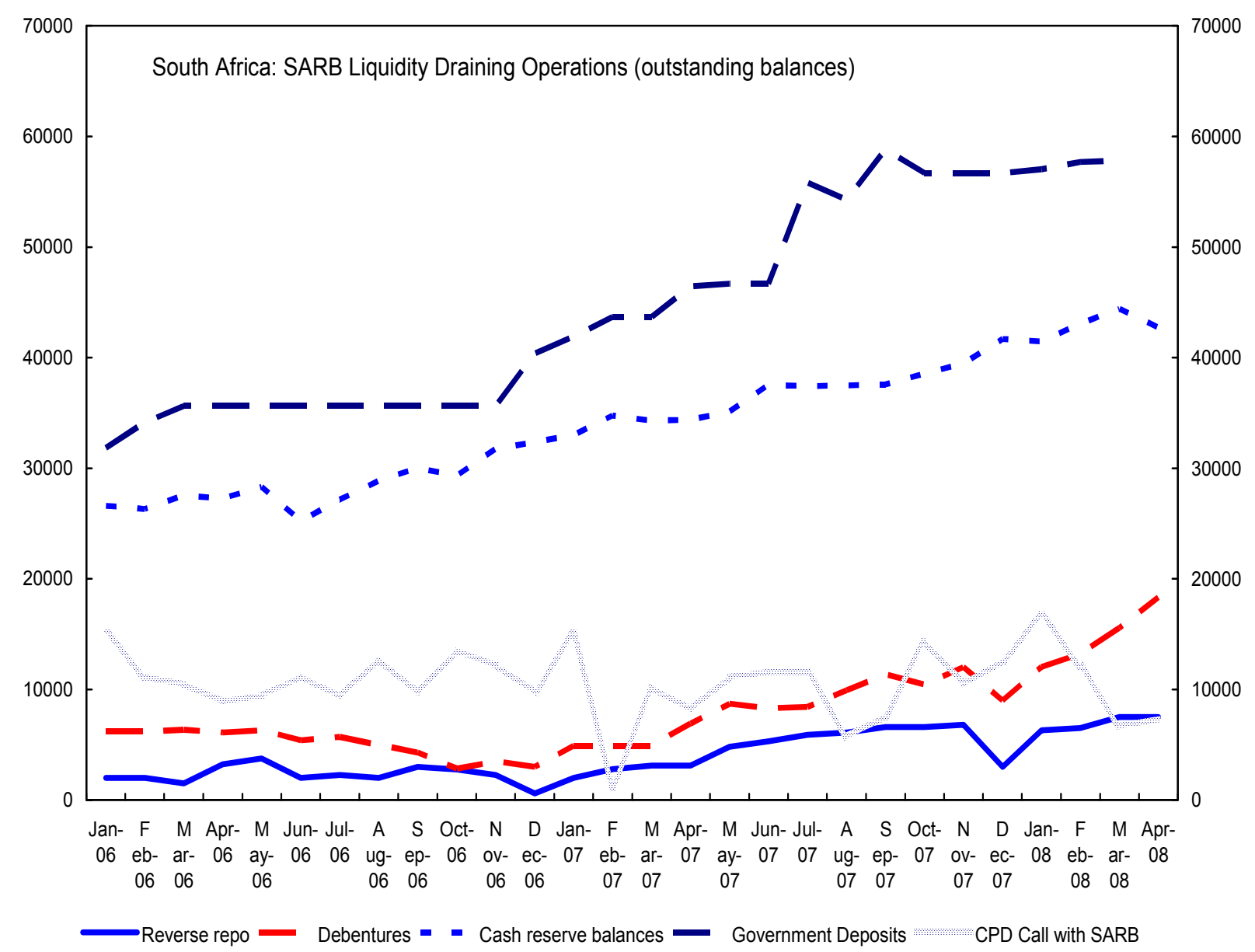

Source: SARB. 
Figure 9. Financial System Development Indicators

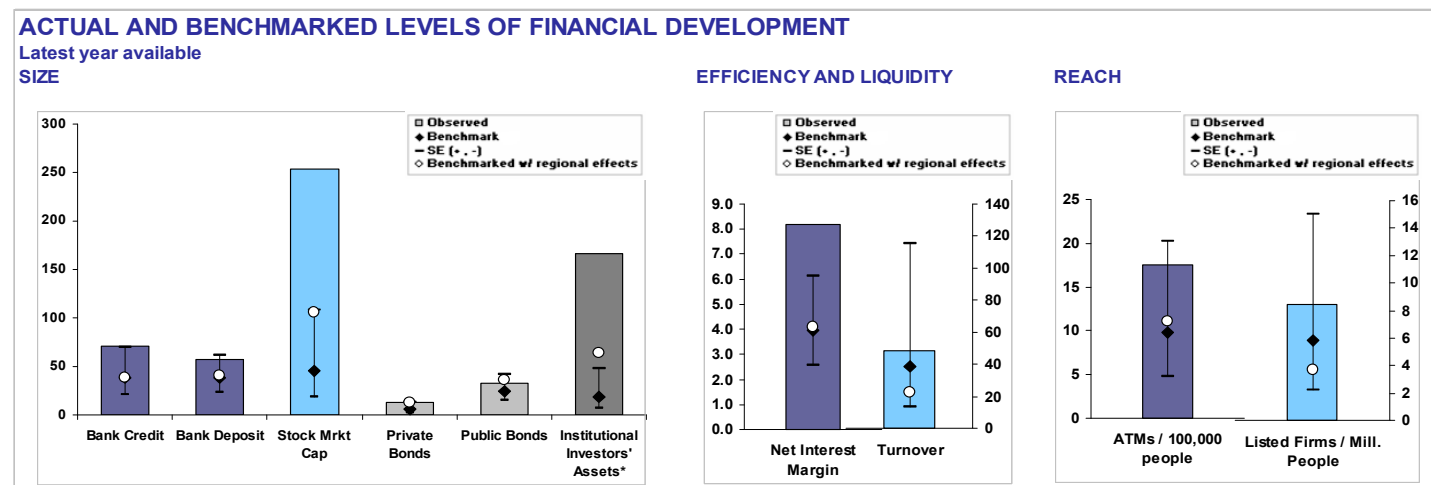

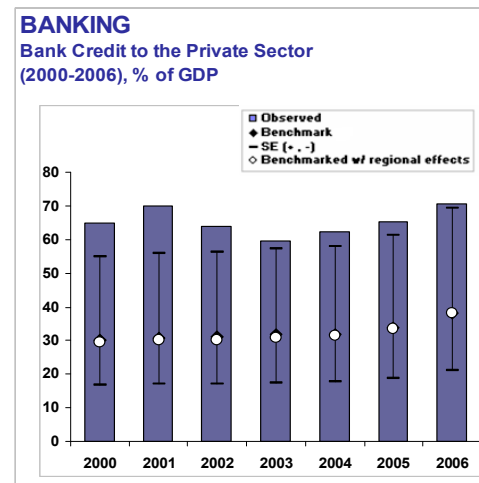

Bank Deposits

(2000-2006), \% of GDP

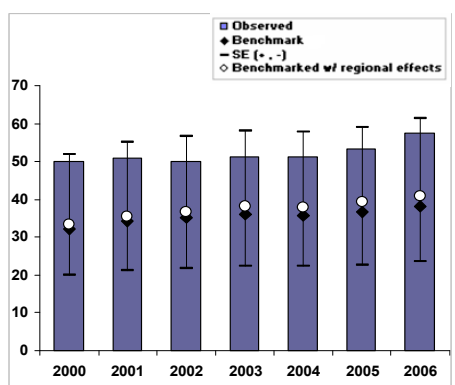

(2000-2006), \% of Asset
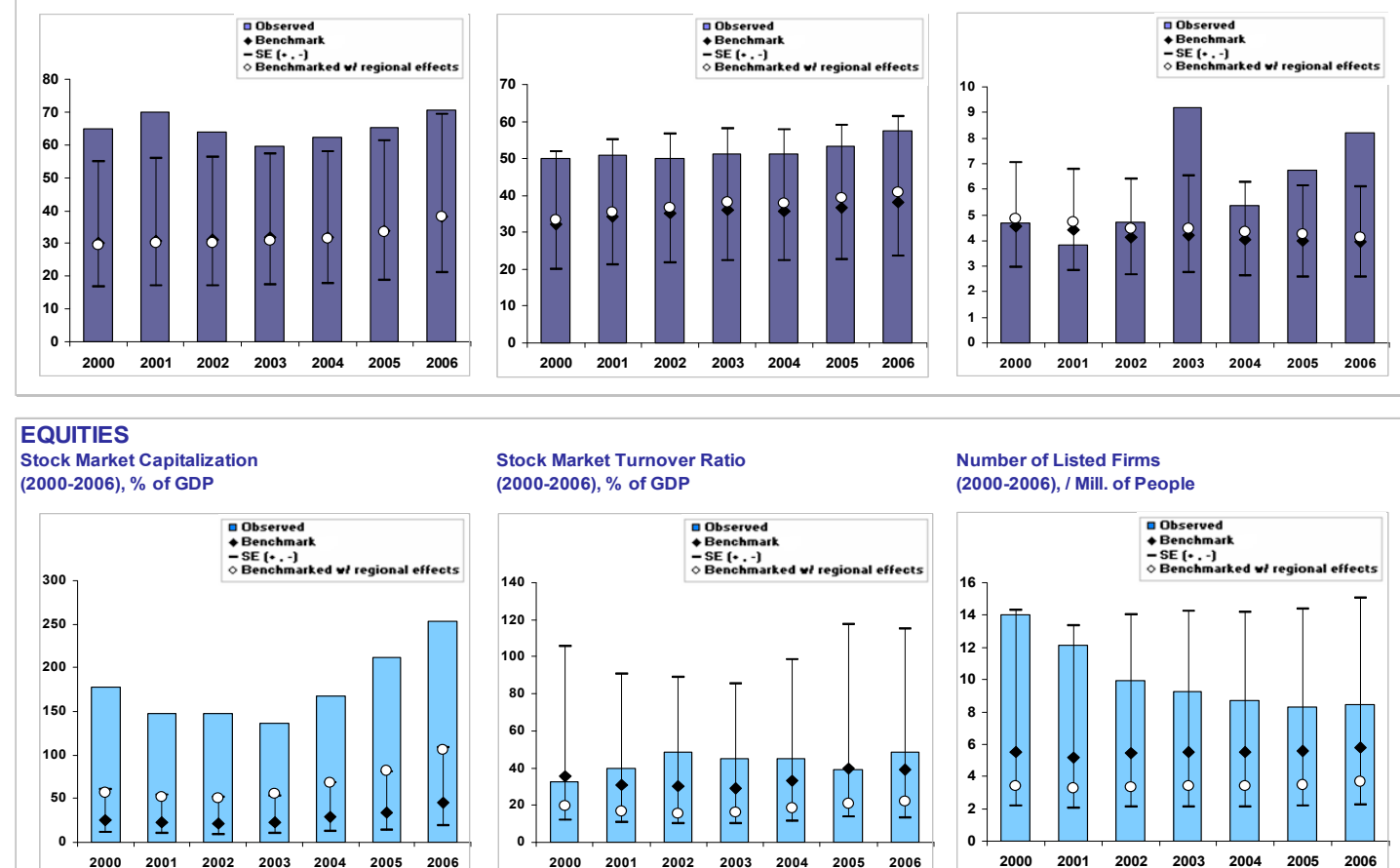

Stock Market Turnover Ratio (2000-2006), \% of GDP

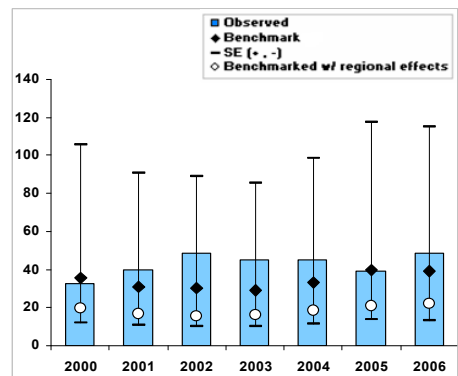

Number of Listed Firms (2000-2006), / Mill. of People
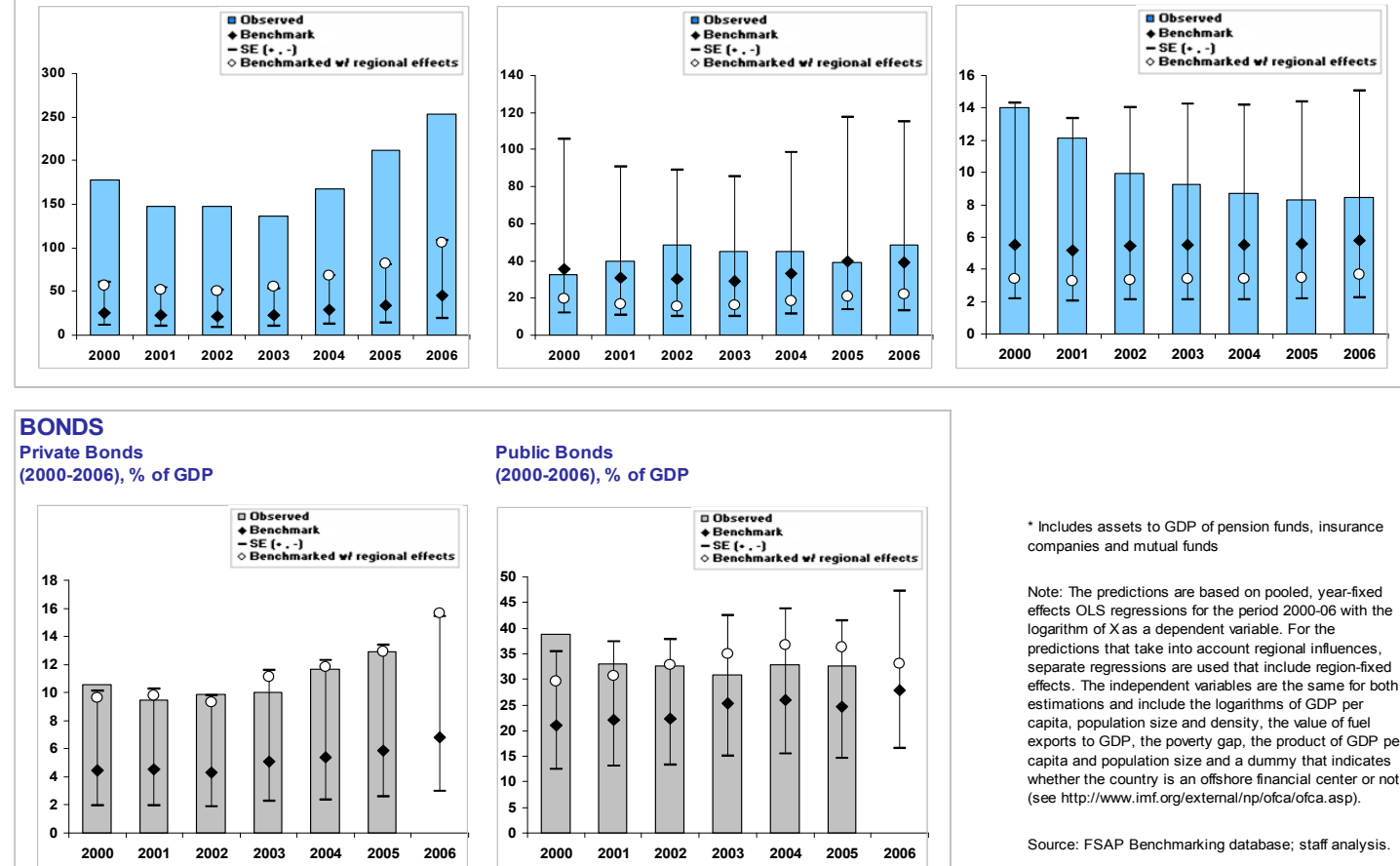

Public Bonds

(2000-2006), \% of GDP

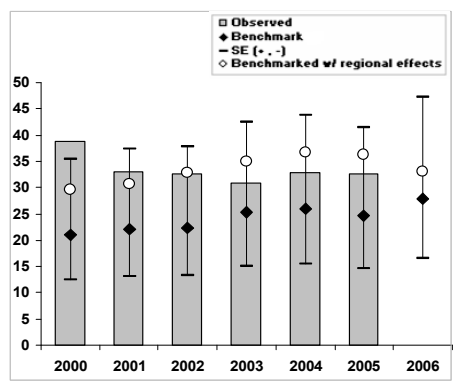

"Includes assets to GDP of pension funds, insurance companies and mutual funds

Note: The predictions are based on pooled, year-fixed effects OLS regressions for the period 2000-06 with the logarithm of $X$ as a dependent variable. For the separate regressions are used that include region-fixed effects. The independent variables are the same for both estimations and include the logarithms of GDP per capita, population size and density, the value of fue exports to GDP, the poverty gap, the product of GDP per whether the country is an offshore financial center or not (see http://wmw.imf.org/external/np/ofca/ofca.asp).

Source: FSAP Benchmarking database; staff analysis.

Source: World Bank estimates. 
Figure 10. Financial System Development

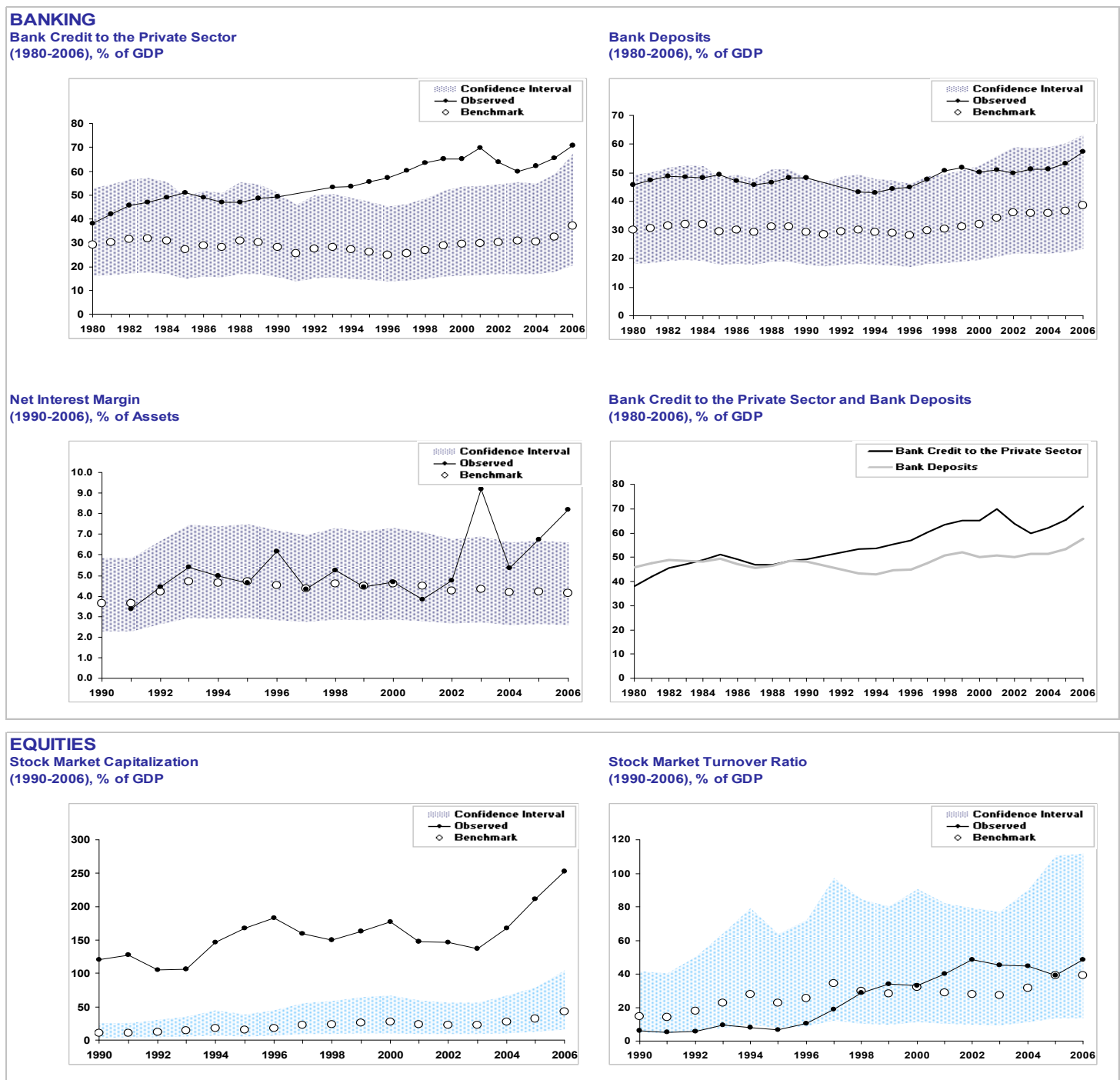

INSTITUTIONAL INVESTORS

Insurance Companies, Mutual Funds and Pension Funds' Assets

(2000-2006 average), \% of GDP

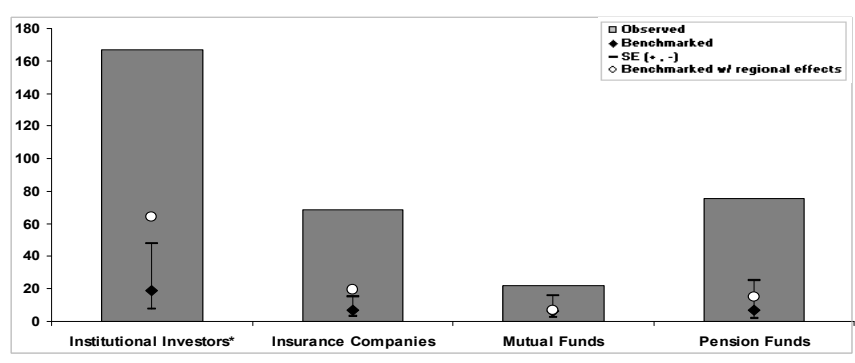

"Includes assets to GDP of pension funds, insurance Note: The predictions are based on pooled OLS Note: The predictions are based on pooled OLS
regressions for the period 1980-2006 with the logarithm of as a dependent variable. The independent variables of and density, the value of fuel exports to GDP, the poverty gap, and a dummy that indicates whether the country is http://www.imf.org/external/np/ofca/ofca.asp). To allow for time-varying coefficients of these indicators, two interactions are added for each of these indicators: one interaction with a time indicator (where 1980 is $t=0$ ) and indicator and its square are also both included as

Source: FSAP Benchmarking database; staff analysis.

Source: World Bank estimates. 


\section{Appendix II. Stress Testing Coverage and Results}

77. This appendix describes the coverage of the stress tests, the methodology used, and the outcomes of stress tests conducted as part of the South Africa FSAP Update. ${ }^{18}$ The tests comprised the large banks and long-term (life) insurance companies. The shocks and the macroeconomic scenario employed in the tests are considered to be severe but plausible. The stress tests are based on end-January 2008 (for the banks) and end-December 2007 (for the bottom-up (BU) analysis of the long-term insurance companies) data. ${ }^{19}$

\section{Coverage}

78. The stress tests centered on the five largest South African banks, and the four largest long-term insurance companies. These five banks together have a 90 percent market share in banking in South Africa, as well as major market shares in several countries in subSaharan Africa (SSA). ${ }^{20}$ The four insurance companies involved in the stress tests together represent 55 percent of the life insurance market in South Africa (by premium income). ${ }^{21}$

79. The stress tests cover all major portfolios of the institutions. Specifically, for the banks, both the trading and the banking book were included in the exercise, as well as all on- and off-balance sheet items. ${ }^{22}$ For the long-term insurance companies, all their life business was included. ${ }^{23}$ The stress tests were performed on the South African domestic legal entities, i.e., excluding any foreign subsidiaries. ${ }^{24}$

\footnotetext{
${ }^{18}$ Details are discussed in a Technical Note on Stress Testing and Short-Term Vulnerabilities.

${ }^{19}$ Top-down (TD) analysis for the insurance companies was done on December 2006 and June 2007 data (see below).

${ }^{20}$ All single-factor results, as well as the TD macroeconomic results, are based on results from the four largest banks only (i.e., excluding Investec), while the BU macroeconomic results are based on the results of all five banks. The 90 percent domestic market share is based on solo data on total credit extended from end-February 2008. Total bank assets in South Africa were equivalent to about 120 percent of GDP in 2007, with 34 commercial banks active in South Africa at end-2007.

${ }^{21}$ The 55 percent domestic market share is based on solo net premium income in 2006.

${ }^{22}$ The TD stress tests were limited to interest rate, equity, and foreign exchange risk for the market risks, and singlefactor credit risk due to data limitations.

${ }^{23}$ Overseas parents were excluded. The TD insurance stress tests were limited to equity, foreign exchange, and real estate risk for the market risk stress tests and mortality, morbidity, and longevity risks for the insurance stress tests. However, due to data limitations, the results varied widely and could not be reconciled with BU results.

${ }^{24}$ For the banks, in the BU analysis, foreign branches were included, while these were excluded in the TD stress tests.
} 
80. The stress testing exercise aims to include all major risks faced by financial institutions. For both banks and insurance companies, these consisted of single-factor tests for market risks, such as interest rates, asset (equity and real estate) prices, exchange rates, volatility, and credit spreads. In addition, for the banks, concentration risk and credit risk were assessed. The latter was done both by single-factor shocks to probabilities of default (PDs) and loss-givendefault (LGDs), as well as by a medium-term macroeconomic scenario, in which resilience against a three-year recessionary environment was tested. The macroeconomic scenario centered around a worldwide recession, with a concomitant decrease of 50 percent in commodity prices. For the insurance companies specifically, single-factor shocks to mortality, morbidity, and longevity were added.

81. In addition to the scenario and single factor tests, assessments of short-term vulnerabilities were made. This was done by focusing on liquidity, through a qualitative as well as a limited quantitative analysis. Operational risk was not assessed.

\section{Methodology}

82. The stress testing approach used in the bottom-up (BU) exercise builds on the expertise of the individual financial institutions. The tests on credit, market, and insurance risks were performed using the institution's own internal risk models. For the macroeconomic scenarios, to enhance consistency, the banks were provided with estimates for the (absolute changes in) PDs. Banks used these PDs to estimate the impact on their portfolio. All results were reported in millions of rands additional expected losses, and were translated into impact on capital and solvency ratios for the banks and insurance companies, respectively.

\section{The short-term vulnerability assessments of liquidity focused on the five large} banks. It consisted of a questionnaire, and two scenarios, in which the liquidity of assets was shocked. The focus of the first scenarios was on three-months funding liquidity, while the second scenario is akin to a one month single-name crisis.

\section{The top-down(TD) stress tests depend on modeling based on supervisory returns} data. Similar to the BU approach, the TD approach consisted of tests of the market and credit portfolios of the banks, and market and insurance risks for the life companies. The TD stress tests were performed on end-January 2008 and end-2007 data for the banks and insurance companies, respectively. For the insurance companies, the TD stress tests were based on the latest available audited returns. In three cases this was December 2006 data, while in one case it was June 2007 data. Results were obtained in millions of rand.

85. The TD analysis was partial due to data limitations. Supervisory returns data did not suffice to perform all stress tests that were performed BU. For the banking sector stress tests, TD analysis could not be performed for real estate and volatility risk. A credit spread shock could be modeled, but the results could not be reconciled with the BU results, and have been omitted. On the insurance side, the data limitation issues proved more serious. TD analysis proved impossible for interest rate, volatility, and credit spread risk. For the other risks, however, the results could 
not be reconciled with the BU results mainly due to timing differences in the information used. For this reason, the TD results for life insurance have been omitted.

86. In both banking and insurance, the favorable macroeconomic developments over the last several years up until 2007 in South Africa cushion the results. The starting position of the banking system is unusually strong, with ample capitalization after a number of year of stable macroeconomic growth. In addition, credit risk indicators and loan loss provisions based on data from this period are likely to underestimate risks, especially on the corporate side. This suggests that, in the absence of suitable stresses to the data, model risk might be present, and calls for conservative credit risk assumptions. Such assumptions are generally made, and the SARB was instrumental in ensuring that banks adopt conservative assumptions during the IRB application process. However, such assumptions necessarily rely to a large degree on judgment, and vigilance is essential in this regard. For the life companies, the favorable investment climate has resulted in historically high bonus stabilization and investment reserves. Without these reserves, several of the single-factor shocks employed would have affected solvency buffers to a larger extent.

87. In addition, some general methodological caveats apply. The single-factor shocks do not attempt to assess the interaction with other changes which might occur simultaneously in case of a shock. The macroeconomic stress testing models lack an interaction or feedback component between the different financial institutions, and no reaction by the banks to the stress scenario is modeled or assumed. Some other caveats lie in the variety of models used and actual portfolios held by the different institutions. In addition, specifically for the TD stress tests, important caveats related to data limitations (see above).

\section{Single-factor market risk shocks}

88. Banks were asked to calculate the impact of a variety of major instantaneous shocks on their portfolios, consisting of both the trading and banking books. In general, these shocks were calibrated to historical data in order to be severe but plausible, and in line with those employed in recent FSAPs for comparable countries. Tests were performed covering shocks to the (rand) interest rate curve; rand exchange rates; asset prices (foreign and domestic equity indices, as well as real estate prices); implied volatilities; and credit spreads. Effects of instantaneous repricing as well as one-year profit and loss account impact were reported. The shocks are summarized in Appendix Table 10. 


\section{Appendix Table 9. South Africa: Single-Factor Market Risk Shocks for Banks}

\section{Interest rates}

Parallel upward shift of the rand yield curve by $600 \mathrm{bps}$.

Parallel downward shift of the rand yield curve by 400 bps.

Steepening of the rand yield curve by $500 \mathrm{bps}$, linearly spread between the overnight and 10-year rate.

Flattening of the rand yield curve by $500 \mathrm{bps}$, linearly spread between the overnight and 10-year rate.

\section{Asset prices}

Decline in domestic equity prices by 35 percent.

Decline in foreign equity prices by 35 percent.

Decline in domestic and foreign equity prices by 35 percent.

Decline in residential real estate prices by 30 percent.

Decline in commercial real estate prices by 50 percent.

Decline in residential real estate prices by 30 percent and commercial real estate prices by 50 percent.

\section{Exchange rates}

Depreciation of the rand by 50 percent versus all other currencies.

Appreciation of the rand by 50 percent versus all other currencies.

\section{Implied volatility}

Doubling of implied volatility (interest rates, equities and exchange rates).

Halving of implied volatility (interest rates, equities and exchange rates).

\section{Credit spread}

Increase of credit spreads by 50 percent on all parties other than governments.

Source: IMF staff calculations.

89. Long-term insurance companies were asked to calculate the impact of a similar set of market risk shocks, but in addition applied a number of insurance risk shocks. The focus for the many market risks was on the main risks for life insurers, i.e., interest rates and asset prices. Shocks to exchange rates, volatility, and credit spreads were also included. The insurance risks employed in the stress tests related to mortality, morbidity, and longevity risk, and were calibrated in discussions with the FSB and the industry to be severe but plausible (Appendix Table 9). Effects of instantaneous repricing as well as one-year profit and loss account impact were reported. 


\section{Appendix Table 10. South Africa: Single-Factor Market and Insurance Risk Shocks for Life Insurers}

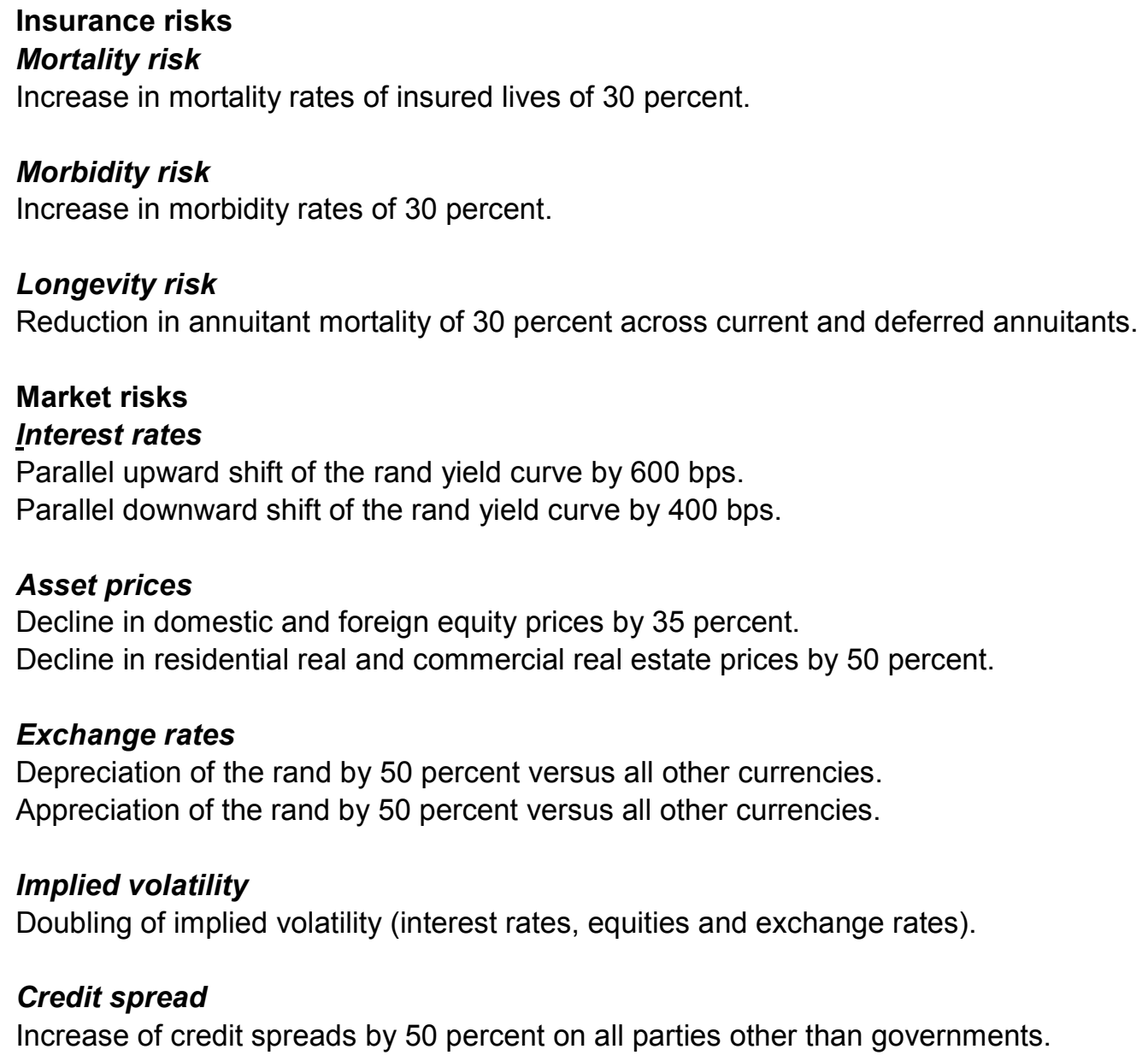

\section{Asset prices}

Decline in domestic and foreign equity prices by 35 percent.

Decline in residential real and commercial real estate prices by 50 percent.

\section{Exchange rates}

Depreciation of the rand by 50 percent versus all other currencies. Appreciation of the rand by 50 percent versus all other currencies.

\section{Implied volatility}

Doubling of implied volatility (interest rates, equities and exchange rates).

Credit spread

Increase of credit spreads by 50 percent on all parties other than governments.

Source: IMF staff calculations.

\section{Credit risk}

90. Credit risk tests were performed both as single-factor shocks, as well as in the context of a macroeconomic scenario. The single-factor shocks are detailed in Appendix Table 11. The macroeconomic scenario stress tests focused on a three-year recessionary scenario. The scenario is simulated on quarterly data, starting in the first quarter of 2008, and develops over a three-year horizon. The scenario assumed a world-wide recession, driven by recessions in some major developed economies and slower growth in 
important emerging market economies. As a consequence, world GDP declines by up to 1.6 percent in the last quarter of Year 1 , after which it gradually recovers. ${ }^{25}$ At the same time, lower demand for commodities is assumed to lead to a halving of commodity prices over two years. These shocks have considerable impact on the rand exchange rate and some of the real variables in the South African domestic economy (Appendix Table 12). The decline in GDP under the scenario is more severe than any recession South Africa experienced since World War II.

\section{Appendix Table 11. South Africa: Single-Factor Credit Risk Shocks for the Banks}

\section{Concentration}

Default of the largest three exposures (excl. government and interbank).

\section{PD-LGD shocks}

Default of all counterparties with PDs above 10 percent

Doubling of all PDs with a simultaneous increase of LGDs by 20 percent (with the exception of government bonds).

Source: IMF staff estimates.

\section{Appendix Table 12. South Africa: Macroeconomic Variables Under the Shock Scenario}

(Deviations from baseline levels)

\begin{tabular}{|r|c|c|c|c|c|c|}
\hline & Commodity prices & World GDP growth & SA GDP growth & SA interest rate & CPI Inflation & Nominal exchange rate \\
\cline { 2 - 7 } & $\begin{array}{c}\text { deviations from } \\
\text { 2007Q4 }\end{array}$ & $\begin{array}{c}\text { annual average } \\
\text { growth rate }\end{array}$ & $\begin{array}{c}\text { annual average } \\
\text { growth rate }\end{array}$ & $\begin{array}{c}\text { annual average } \\
\text { changes }\end{array}$ & $\begin{array}{c}\text { annual average } \\
\text { changes }\end{array}$ & $\begin{array}{c}\text { year-end deviations } \\
\text { from 2007Q4 }\end{array}$ \\
\cline { 2 - 7 } Year & (in percent) & (in percent) & (in percent) & $\begin{array}{c}\text { (in percentage } \\
\text { point) }\end{array}$ & $\begin{array}{c}\text { (in percentage } \\
\text { point) }\end{array}$ & $\begin{array}{c}\text { (depreciation in } \\
\text { percent) }\end{array}$ \\
\hline 2008 & -36 & -0.7 & -3.4 & -0.6 & 1.3 & 13.9 \\
2009 & -50 & -1.2 & -0.7 & -3.3 & -2.6 & 11.0 \\
2010 & -33 & -0.1 & 2.5 & 0.4 & -0.9 & 9.0 \\
\hline
\end{tabular}

Source: IMF staff assumptions and estimates.

\footnotetext{
${ }^{25}$ In the model, this shock was simulated by a combination of a world productivity shock and a shock to foreign demand for South African exports.
} 
91. In order to assess the effect of a macroeconomic stress scenario on credit risk in the banking sector, some measure of credit risk has to be linked to the macroeconomic variables describing the scenario. This is done by an econometric (logistic) model linking the macro-variables to probabilities of default of customers in different economic sectors. For each sector in the South African economy, PDs were estimated as a function of the macroeconomic variables, and out of sample PDs under the stress scenario were calculated. The main macroeconomic variables employed in the regressions are household consumption, long-term interest rates, inflation, and the unemployment rate. The regression coefficients were subsequently used to calculate out of sample PDs under the stress scenario for Year $1-3 .{ }^{26}$ Further details can be found in the accompanying Technical Note on Stress Testing and Short-Term Vulnerabilities.

\section{Liquidity shocks}

92. Short-term vulnerabilities were assessed by focusing on liquidity. The banks were asked to run two specific liquidity scenarios. The first scenario assumed the spread between the secured and unsecured rand money market rates to increase by $600 \mathrm{bps}$. At the same time the pool of collateral accepted by parties in the secured market (with the exemption of government bonds) would shrink by 30 percent. Furthermore, 30 percent of currently eligible assets (again with the exemption of government bonds) would fall below the reserve bank's threshold for accepting them as collateral. This situation is assumed to last for three months, and the banks were asked to report the effects on their liquidity situation after 30,60, and 90 days. The second scenario is akin to a name crisis. It assumes a withdrawal of 15 percent of deposit over a one month's period, while simultaneously 50 percent of committed credit lines are tapped, and liquid assets take a 20 percent haircut.

\section{Results}

93. Market risks generally do not seem to be a major source of risk for the large South African banks (Appendix Table 13 and Figure 11). For the banks, interest rate risk dominates the other risks assessed, but remains limited. This is largely due to the fact that almost all assets (loans) are at floating rates. Hence, interest rate increases can be passed through to clients almost instantaneously and the repricing risk in very limited. An instantaneous 400 bps decrease across the entire rand yield curve would lead to losses corresponding to a decrease in capital of 0.5 percentage points on average, against an average capital ratio of 11.4 percent (for the four large banks) before the shock. The limited effect is driven by the fact that almost all lending is at variable rates and would, hence, be repriced quickly. A steepening or flattening of the curve would lead to moderate losses. Here, the dispersion of the estimated effects across banks was large, driven by the fact that some banks stand to gain from a flattening (steepening), while others tend to lose from these scenarios. In

\footnotetext{
${ }^{26}$ As the estimation was done on a relatively short time series of PD data, a scaling factor was employed to bring estimates in line with default rates in previous downturns.
} 
none of the market risk scenarios did any of the banks end up with a capital ratio below the regulatory minimum of 9.75 percent.

\section{Appendix Table 13. South Africa: Market Risks Stress Tests for the Banks}

(Total impact in percentage point of capital)

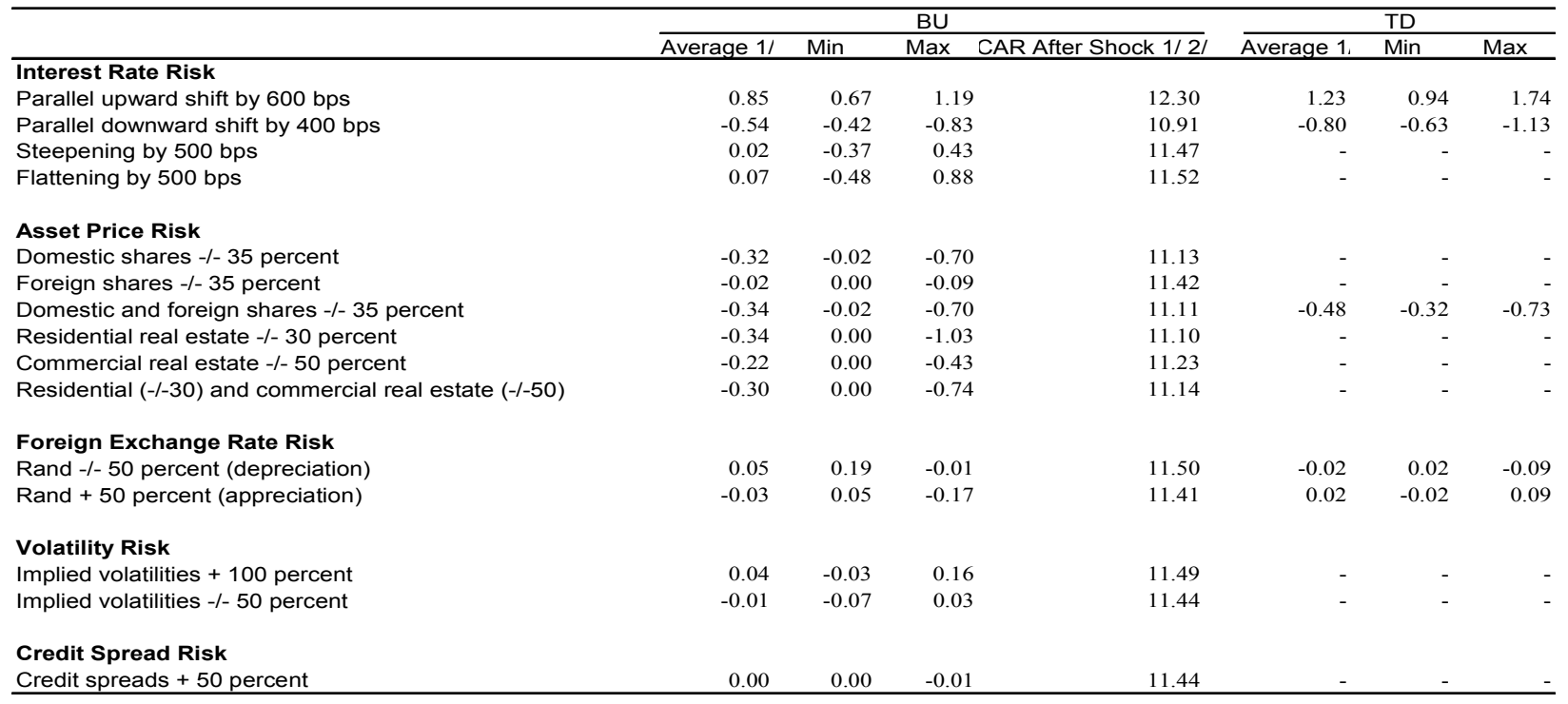

Source: Individual banks, SARB, and IMF staff calculations.

1/ Unweighted average across the four banks.

2/ The unweighted average CAR across the four banks before the shocks is 11.4 percent.

94. Other market-risk risk factors, such as exposures to equities, real estate, derivatives, and credit spreads, are estimated to be minor compared to interest rate risk. A 35 percent decline in the price of domestic shares on average costs the banks 0.3 percentage point of capital (resulting, on average, in a capital adequacy ratio (CAR) of 11.1 percent $)^{27}$, while a simultaneous decline in residential (30 percent) and commercial (50 percent) real estate would imply an equivalent average loss, caused by an increase in NPLs. ${ }^{28}$ A 50 percent rand depreciation would on average result in a small gain for the banks, while an equivalent appreciation would result in a loss. This, however, is mainly driven by translation risk (i.e., participations in foreign subsidiaries held in foreign currency), rather than active positions. Volatility and credit spread risks are minor.

95. Differences between BU and TD results are not large. They are mainly driven by the fact that the TD analysis is by necessity less granular than the banks' own analysis. It

\footnotetext{
${ }^{27}$ This impact is roughly linear in the magnitude of the shock, as it is a direct shock to bank's equity holdings.

${ }^{28}$ Bank's direct exposure to residential property through so-called properties in possession, is minimal. The effect on capital is through increased probabilities of default and loss given default, i.e., increased NPLs.
} 
hence incorporates additional assumptions, primarily on exposures. These assumptions are generally conservative, as also evidenced by the generally larger impact obtained from TD analysis compared to BU analysis.

Figure 11. South Africa: Market Risk Stress Tests for the Banks

(Impact in percentage point of capital)

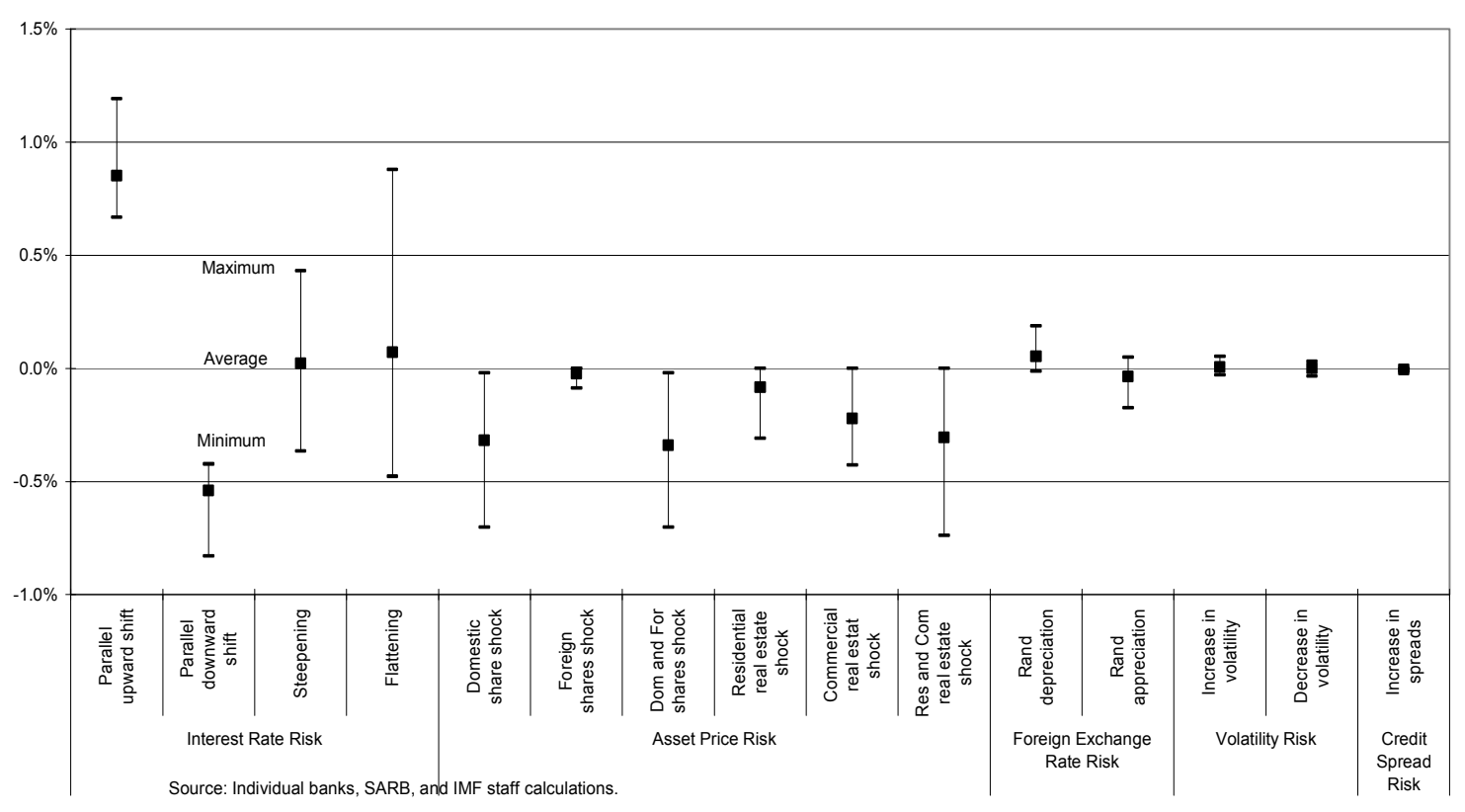

96. The life insurance companies are more exposed to market risks (Appendix Table 14 and Figure 12). An instantaneous 400 bps parallel downward shift in the rand yield curve has a large impact on two out of the four insurers. While the average impact is large, at 2.1 percentage point of the solvency ratio, ${ }^{29}$ which stands at 7.7 on average before the shocks (i.e., after the shock, the solvency ratio, on average, stands at 5.6). Two companies are particularly affected by this shock. In one instance this is due to the use of retrospective rather than prospective valuation techniques. ${ }^{30}$ In the other case, however, the impact stems

\footnotetext{
${ }^{29}$ The solvency ratio is defined as the total capital (which is equal to the regulatory capital requirement plus the buffer above the regulatory capital requirement) divided by total assets. This is equivalent to the definition of the capital ratio in banking.

${ }^{30}$ A prospective valuation sets the_mathematical reserves at the present value of future net cash flows. A retrospective method typically sets the mathematical reserves at the level of premiums received (and accumulated with investment return), less claims and expenses paid. Hence, retrospective valuation assumes that premiums are adequate to cover future claims and expenses. Especially in cases of unexpected shocks, the two methodologies might produce very different outcomes. Here, using a prospective rather than a retrospective valuations method would have resulted in larger buffers, and hence, would have cushioned the results.
} 
from the relatively large portfolio of guaranteed products in the company's portfolio of liabilities. Indeed, this company continues to write significant amounts of guaranteed policies, while the others have to a large extent, moved away from this business line.

97. Most of the life companies are also heavily exposed to declines in equity prices. They mostly have large portfolios of equities. While much of the risk in these portfolios is transferred directly to policy holders, significant risk remains on the books of the companies, often in the form of minimum guaranteed return products or smooth bonus products (for which parts of previously disbursed bonuses are also guaranteed). A 35 percent decline in the price of domestic and foreign shares would result in a decrease of the solvency ratio by 0.8 percentage point on average, to 7.0 .

98. Other market risks are more moderate, with the exception of volatility risk. Exposure to foreign exchange risk and credit risk seems moderate or minor. The exposure to volatility seems large, as seen from the implied volatility shock. This is mainly driven by the nonlinear increases in reserves that need to be held to cover guaranteed products in such a more volatile environment. However, the companies also indicated that their valuation models were ill-equipped to handle such large volatility shocks, and that the numbers represent rough and conservative approximations. As a result, the estimated impact varied widely from company to company.

99. Insurance risks, and mortality and longevity risks in particular, are important risk for life insurers (Appendix Table 14 and Figure 12). An unexpected permanent increase in mortality rates of 30 percent reduces solvency ratios by an average of 1.0 percentage point. An average reduction in the rate of annuitant mortality (i.e., an upward shock to longevity) impacts solvency ratios by an average of 0.6 percentage point. Exposure to morbidity risk is lower, since the volume of these policies is more modest. A permanent increase in morbidity rates of 30 percent would result in a 0.2 percentage point reduction in solvency ratios on average.

100. Generally, offsetting factors could mitigate these results in practice. A higher mortality rate, for instance, would imply a profit on the annuity portfolio (i.e., a decrease in longevity), while an increase in longevity implies on average lower mortality. In addition, the companies currently all use the U.K. mortality tables, which have a gradual increase in longevity built in. This seems to be a conservative and prudent approach to longevity risk; while the increase in longevity over the coming decades might be similar to the U.K. for the high-income categories in South Africa, and for the lower income categories this does not seem to be the case, as mortality rates in this category are currently up to ten times higher than in the high-income categories. Assuming the expected U.K. increase in longevity for South Africa, hence, seems conservative. The companies also informed the mission on flu pandemic scenarios that they have run in the past. Generally, offsetting factors implied that the losses under a wide range of flu pandemic scenarios would remain manageable.

\section{Credit risk stress tests showed a substantial impact on the banks}

(Appendix Table 15). This is the case for the single-factor credit stress tests, as well as for 
the macroeconomic scenario stress test. Credit risk stress scenarios were not run for the insurance companies.

\section{Appendix Table 14. South Africa: Market and Insurance Risk Stress Tests for the Long-Term Insurers}

(Impact in percentage point of solvency ratio)

\begin{tabular}{|c|c|c|c|c|}
\hline \multirow{2}{*}{ Insurance Risks } & \multicolumn{4}{|c|}{$\mathrm{BU}$} \\
\hline & Average $1 /$ & Min. & Max. & Solvency Ratio After Shock 1/ 2/ \\
\hline \multirow{2}{*}{\multicolumn{5}{|c|}{ Mortality Risk }} \\
\hline & & & & \\
\hline Mortality rates +30 percent & -1.01 & -0.60 & -1.35 & 6.72 \\
\hline \multicolumn{5}{|l|}{ Morbidity Risk } \\
\hline Morbidity rates +30 percent & -0.22 & 0.00 & -0.42 & 7.51 \\
\hline \multicolumn{5}{|l|}{ Longevity Risk } \\
\hline Annuant mortality $-/-30$ percent & -0.61 & -0.36 & -0.87 & 7.13 \\
\hline \multicolumn{5}{|l|}{ Market Risks } \\
\hline \multicolumn{5}{|l|}{ Interest Rate Risk } \\
\hline Parallel upward shift by 600 bps & -0.04 & 0.60 & -1.32 & 7.70 \\
\hline Parallel downward shift by $400 \mathrm{bps}$ & -2.10 & -0.34 & -3.86 & 5.63 \\
\hline \multicolumn{5}{|l|}{ Asset Price Risk } \\
\hline Domestic and foreign shares $-/-35$ percent & -0.78 & 0.64 & -1.36 & 6.95 \\
\hline Residential and commercial real estate $-/-50$ percent & 0.00 & 0.41 & -0.50 & 7.74 \\
\hline \multicolumn{5}{|l|}{ Foreign Exchange Rate Risk } \\
\hline Rand -/- 50 percent (depreciation) & 0.01 & 0.17 & -0.23 & 7.74 \\
\hline Rand +50 percent (appreciation) & -0.29 & 0.05 & -0.78 & 7.44 \\
\hline \multicolumn{5}{|l|}{ Volatility Risk } \\
\hline Implied volatilities +100 percent & -1.61 & -0.10 & -3.18 & 6.12 \\
\hline \multicolumn{5}{|l|}{ Credit Spread Risk } \\
\hline Credit spreads +50 percent & -0.07 & 0.01 & -0.21 & 7.66 \\
\hline
\end{tabular}

Source: Individual long-term insurers and IMF staff calculations.

1/ Unweighted average across the four insurance companies.

$2 /$ The unweighted average solvency ratio across the four insurers before the shocks is 7.7 percent.

102. Concentration risk is substantial. Defaulting the three largest exposures of the banks resulted on average in a loss equivalent to 2.2 percentage point of capital, resulting in an average CAR of 9.3 percent. In this scenario, three of the large fours banks would fall below the 9.75 percent regulatory minimum capital requirement. Concentration risk is a feature of the South African system, where a limited number of large corporates operate in a medium-sized economy featuring exchange controls. However, these corporates generally have high credit ratings and are not highly leveraged. 
Figure 12. South Africa: Life Insurance Stress Test Results (Impact in percentage point of solvency ratio)

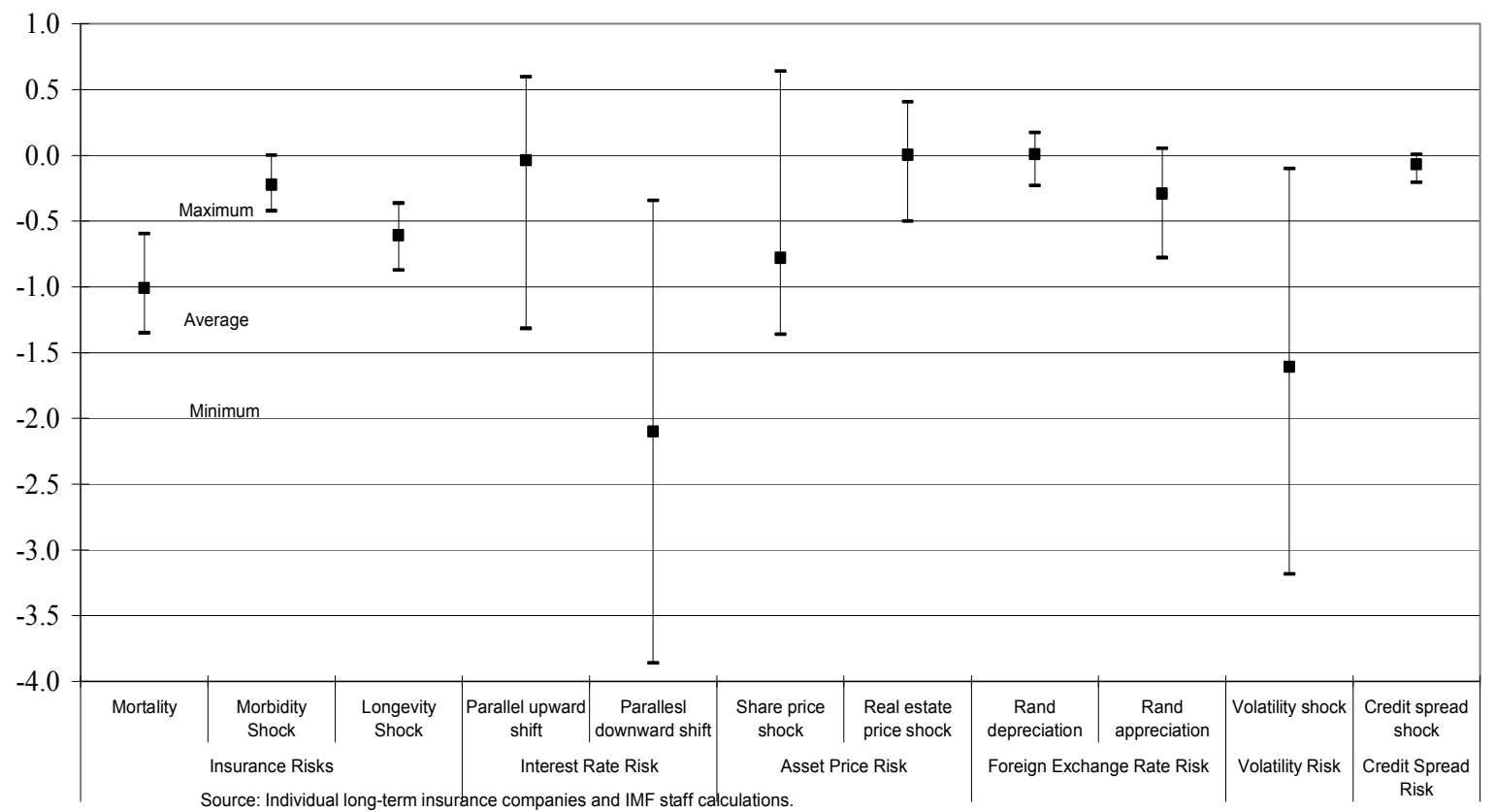

\section{Appendix Table 15. South Africa: Credit Risk Stress Tests for the Banks}

(Total impact in percentage point of capital)

\begin{tabular}{|c|c|c|c|c|c|c|c|}
\hline & \multicolumn{3}{|c|}{$\mathrm{BU}$} & \multirow[b]{2}{*}{ CAR After Shock 1/ $2 /$} & \multicolumn{3}{|c|}{ TD } \\
\hline & Average 1/ & $\operatorname{Min}$ & $\operatorname{Max}$ & & Average 1/ & $\operatorname{Min}$ & $\operatorname{Max}$ \\
\hline \multicolumn{8}{|l|}{ Concentration Risk } \\
\hline Default of 3 largest exposures & -2.16 & -1.78 & -2.82 & 9.29 & - & - & - \\
\hline \multicolumn{8}{|l|}{ Single-Factor Credit Risk } \\
\hline Default all counterparties with $P D>10$ percent & -2.64 & -2.00 & -3.74 & 8.80 & -0.72 & -1.02 & -0.30 \\
\hline \multicolumn{8}{|l|}{ Macroeconomic Scenario 3/ } \\
\hline Total & -1.77 & -0.62 & -2.55 & 9.91 & -1.96 & -1.52 & -2.34 \\
\hline of which: Year 1 & -0.92 & -0.36 & -1.52 & 10.76 & -1.08 & -0.89 & -1.23 \\
\hline Year 2 & -0.65 & -0.22 & -0.87 & 10.12 & -0.77 & -0.59 & -0.94 \\
\hline Year 3 & -0.21 & -0.04 & -0.53 & 9.91 & -0.11 & -0.04 & -0.17 \\
\hline
\end{tabular}

Source: Individual banks, SARB, and IMF staff calculations.

$1 /$ Unweighted average across the four (concentration and single-factor credit risk) and five (macro scenario) banks.

2/ The unweighted average CAR across the four banks before the shocks is 11.4 percent. Including Investec (in the BU macroeconomic scenario),

this average is 11.7 percent. The impact on the CAR in the macro scenario is cumulative over three years.

3/ The macroeconomic scenario comprises five banks in the BU analysis and four banks in the TD analysis (Investec is excluded).

103. Single-factor credit risk shocks also show a sizeable impact. Defaulting all counterparties with the PD above 10 percent results on average in a loss of 2.6 percentage point of capital, resulting in an average CAR of 8.8 percent, and would leave all four large banks with a capital ratio below the regulatory minimum of 9.75 percent. This is caused by a 
relatively significant proportion of the retail book currently featuring PDs above 10 percent, resulting in a large exposure to this shock. The shock can, hence, be considered as very severe. ${ }^{31}$ A second single factor shock featuring a 100 percent increase in PDs with a concomitant increase in LDGs of 20 percent has an even larger impact. However, much of this impact is actually caused by an increase in risk-weighted assets, rather than actual losses. As this shock can be considered to be outside the scope of plausibility, the impact is not shown here.

104. The macroeconomic scenario also has a considerable impact. The cumulative impact over three years amounts to 1.8 percentage point of capital, on average across the five banks in the BU analysis, resulting in an average CAR of 9.9 percent. The cumulative threeyear impact would leave the capital ratio at two of the five banks below the regulatory minimum of 9.75 percent. The most severe impact occurs in the first year, when PDs rise the most. The TD results are close to the BU results and, hence, support this analysis. ${ }^{32}$ The impact of the macro scenario in particular can be seen as a conservative estimate, as no profits or management actions are taken into account over the full three years of the scenario. On the other hand, however, the scenario also does not include any feedback effects from financial sector stress to the real economy, or from stress in a particular banks to the wider financial system.

105. The banks all reported that under the liquidity stress scenarios, their liquidity position would remain manageable. Under the first scenario, the impact remains limited due to several factors. First, banks generally do not make much use of secured funding. Hence, a 30 percent haircut on the assets accepted for secured lending does not impact them much. Second, the scenario does not assume any major parties withdrawing funding. Hence, the impact is ultimately more on income, as the banks will have to pay significantly more for their (primarily unsecured) funding.

\section{The second scenario, akin to a limited bank-run, also had only a moderate}

impact. The scenario is seen as a name crisis, similar to what the banks use in internal stress tests. Banks generally would be able to fund themselves in such a scenario by not rolling over short-term assets (which, as they are held to maturity would not take much of a haircut, if any), and possibly selling some of their liquid assets (with a small haircut). Some of the banks remarked that in case this scenario would be seen as a market event, rather than a single-name crisis, they would face serious funding problems. However, in such a circumstance, they deem it extremely unlikely that liquidity would not be forthcoming from the SARB.

\footnotetext{
${ }^{31}$ As most of the loans with PDs above 10 percent are in the retail book, this shock could also be interpreted as a severe retail credit risk shock induced by steep interest rate increases.

${ }^{32}$ The TD results for the macroeconomic scenario are based on four major banks only (i.e., excluding Investec). These four banks all are approved to use internal ratings-based credit models, while Investec is approved to use the standardized approach for credit risk. The difference in reporting at this stage prevents inclusion of Investec in the analysis.
} 
107. TD analysis on liquidity revealed a similar pattern. Banks would generally remain liquid in case of substantial funding pressure. However, the TD analysis was unable to replicate the shocks employed in the BU stress tests, and hence, the results are not directly comparable. In addition, the TD analysis did not calculate the impact on the P\&L.

108. The mission followed up on the quantitative results of the stress tests by conducting in-depth discussion with the risk managers of financial institutions involved. The main conclusions were:

- Stress tests are an integrated part of banks' and insurers' risk management practices at all levels. Risk management practices seem strong. The institutions regularly present stress testing results to senior management, which subsequently decides whether the risks are within their risk appetite, or whether risks should be mitigated, e.g., through hedging or changing positions.

- $\quad$ The stress tests covered most risks, and the scenarios were realistic and presented severe stress. Most institutions internally run additional single-factor stress tests, as well as combinations of single-factor stress tests. In addition, most life insurers have also modeled flu pandemic scenarios.

- Some model risk might be present. The high growth over the last few years has led to currently low-credit risk indicators for corporates. In the retail portfolio, the credit risk has recently started to increase rapidly. As most models are based on data collected (at least in part) during this period, the estimates of credit risk factors derived from these data might be somewhat optimistic.

- The discussion on liquidity issues indicated that banks rely to a large extent on short-term domestic wholesale funding, which presents a vulnerability. Liquidity risk managers generally recognize this risk. However, no banks indicated that they were pursuing an active mitigation strategy of this risk, by, e.g., more longer-term and offshore issuance. The lack of a domestic long-term reference curve plays a role here.

- $\quad$ For insurance companies, the discussions clearly brought out the mismatch between long-dated liabilities and assets. The development of a long-term bond market would, hence, be very beneficial for the life insurance industry. 
Appendix III. Detailed Recommendations ${ }^{33}$

\begin{tabular}{|c|c|c|}
\hline Recommendation & $\begin{array}{l}\text { Agency in } \\
\text { Charge }\end{array}$ & Timeframe \\
\hline \multicolumn{3}{|l|}{ Financial Stability } \\
\hline $\begin{array}{l}\text { Integrate top-down stress testing of individual banks in } \\
\text { financial stability analysis. }\end{array}$ & SARB & ST \\
\hline $\begin{array}{l}\text { Remain vigilant on credit risk in banking, stemming from } \\
\text { retail and concentrated corporate exposures, and on the } \\
\text { funding risks, resulting from reliance on short-term domestic } \\
\text { wholesale funding. }\end{array}$ & SARB & ST \\
\hline $\begin{array}{l}\text { Focus on market risks in the life insurance companies, } \\
\text { and actively engage the long-term insurance companies in a } \\
\text { dialogue about their exposures to these risks. }\end{array}$ & FSB & ST \\
\hline $\begin{array}{l}\text { Strengthen the off-site stress testing capacity and employ } \\
\text { this capacity to inform the regular supervisory } \\
\text { discussions. }\end{array}$ & SARB, FSB & MT \\
\hline \multicolumn{3}{|c|}{ Systemic Liquidity, Crisis Management } \\
\hline $\begin{array}{l}\text { Enhance focus on liquidity and funding issues and } \\
\text { discuss medium-term strategies to reduce banks' } \\
\text { dependency on wholesale market funding. Analyze in a } \\
\text { collaborative exercise between the SARB, the NT, and the } \\
\text { FSB, for instance in the context of a Basel II Pillar } 2 \text { exercise } \\
\text { and in drawing on the results of the planned study of the } \\
\text { effects of an eventual lifting of remaining capital controls. }\end{array}$ & SARB, FSB, NT & ST \\
\hline $\begin{array}{l}\text { Continue the strategy to gradually increase foreign } \\
\text { exchange reserves and consider establishing standing } \\
\text { swap lines with other central banks of the most important } \\
\text { settlement currencies-e.g., the Federal Reserve, the ECB, } \\
\text { and the Bank of England. }\end{array}$ & SARB & MT \\
\hline $\begin{array}{l}\text { Continue cautious approach to foreign exchange regime } \\
\text { liberalization supported by strengthened monitoring and } \\
\text { surveillance with: (i) appropriate timing to minimize the risk } \\
\text { that the measures would need to be reversed; and (ii) proper } \\
\text { reporting by commercial banks, securities dealers, and other } \\
\text { market participants to enable the SARB to take corrective } \\
\text { actions in a timely manner. }\end{array}$ & NT & MT \\
\hline $\begin{array}{l}\text { Review all strategies regarding crisis management as part } \\
\text { of the work of the FSCF in light of past crisis episodes } \\
\text { experienced globally, and consider undertaking a crisis } \\
\text { simulation exercise relating to a macro-financial shock, such } \\
\text { as a capital outflow or distress in a large financial sector } \\
\text { institution. }\end{array}$ & SARB, FSB, NT & ST \\
\hline Clarify bank resolution powers by authorizing the registrar & SARB, NT & MT \\
\hline
\end{tabular}

${ }^{33}$ Short Term (ST), within 12 months. Medium Term (MT), 1-3 years. 


\begin{tabular}{|c|c|c|}
\hline Recommendation & $\begin{array}{l}\text { Agency in } \\
\text { Charge }\end{array}$ & Timeframe \\
\hline \multicolumn{3}{|l|}{$\begin{array}{l}\text { of banks, who has extensive powers to safeguard the } \\
\text { soundness of the banking system, to directly appoint a } \\
\text { curator-limiting the need for the MOF's intervention only in } \\
\text { those cases requiring use of public funds. }\end{array}$} \\
\hline \multicolumn{3}{|c|}{ Foreign Exchange, Capital Markets, and Securities Regulation } \\
\hline $\begin{array}{l}\text { Enhance surveillance of the OTC foreign exchange } \\
\text { derivative markets, by systematically pursuing collection and } \\
\text { analysis of information on offshore activity. }\end{array}$ & SARB & MT \\
\hline $\begin{array}{l}\text { Facilitate further development of the stock and bond } \\
\text { markets and continue gradual liberalization of exchange } \\
\text { controls to attract long-term financing for South Africa's } \\
\text { extensive investment needs. }\end{array}$ & $\begin{array}{l}\text { NT, SARB, JSE, } \\
\text { FSB }\end{array}$ & MT \\
\hline $\begin{array}{l}\text { Consider consolidation of the responsibility for corporate } \\
\text { disclosure of listed securities in the FSB. }\end{array}$ & FSB & MT \\
\hline $\begin{array}{l}\text { Require the } \mathrm{ACI} \text { to register as an SRO. The FSB should } \\
\text { reexamine whether it should continue to delegate critical } \\
\text { responsibilities for the regulation of the unit trust market } \\
\text { unless the } \mathrm{ACl} \text { assumes SRO status and increases its } \\
\text { resources and enforcement capacity. }\end{array}$ & FSB & MT \\
\hline $\begin{array}{l}\text { Assess ability to effectively oversee continued expansion } \\
\text { in the OTC market in equity-linked derivatives within the } \\
\text { current structure. Consider improved reporting of OTC } \\
\text { trading and position concentration by JSE's member firms, } \\
\text { and adoption of margin and concentration rules for member } \\
\text { firms trading OTC. }\end{array}$ & JSE & MT \\
\hline $\begin{array}{l}\text { Effect change in settlement cycle on JSE from } T+5 \text { to } \\
T+3 \text {. }\end{array}$ & JSE & MT \\
\hline $\begin{array}{l}\text { Increase the size of fines that can be imposed by the JSE, } \\
\text { the ACI, and the IRBA to a level that provides a meaningful } \\
\text { deterrent commensurate with the significance of the } \\
\text { misconduct. FSB's policy of "name and shame" should be } \\
\text { adopted by these other organizations. }\end{array}$ & JSE & MT \\
\hline \multicolumn{3}{|c|}{ Financial Sector Supervision and Regulation } \\
\hline $\begin{array}{l}\text { Enhance day-to-day collaboration amongst the staff of the } \\
\text { different sectoral regulators, in respect of individual } \\
\text { institutions and emerging risk issues. }\end{array}$ & FSB, SARB, NCR & ST \\
\hline $\begin{array}{l}\text { Increase focus on qualitative standards, including } \\
\text { corporate governance, risk management, and internal } \\
\text { controls. }\end{array}$ & FSB & MT \\
\hline $\begin{array}{l}\text { Develop the skills of supervisors to meet the growing } \\
\text { complexity of the regulatory requirements and the demands of } \\
\text { taking a less compliance-based approach to supervision. }\end{array}$ & FSB & MT \\
\hline $\begin{array}{l}\text { Further develop risk assessment models, taking a more } \\
\text { consistent approach across sectors, and the creation of } \\
\text { increased central capacity at the main regulators to identify } \\
\text { risk and allocate resources flexibly to issues as they arise. }\end{array}$ & FSB,SARB & MT \\
\hline $\begin{array}{l}\text { Consider a mechanism for resolving policy } \\
\text { disagreements among different regulators and }\end{array}$ & SARB, FSB, NT & MT \\
\hline
\end{tabular}




\begin{tabular}{|c|c|c|}
\hline Recommendation & $\begin{array}{c}\text { Agency in } \\
\text { Charge }\end{array}$ & Timeframe \\
\hline \multicolumn{3}{|l|}{$\begin{array}{l}\text { departments and assessing trade-offs among differing } \\
\text { policy objectives. The Policy Board for Financial Services } \\
\text { and Regulation was created to ensure better coordination, but } \\
\text { it plays a purely advisory role to the NT. }\end{array}$} \\
\hline $\begin{array}{l}\text { Consider a more risk-sensitive approach to loans where } \\
\text { the borrower has contributed minimum (or zero) equity, } \\
\text { including residential mortgage loans with very high loan-to- } \\
\text { valuation ratios. }\end{array}$ & SARB & ST \\
\hline \multicolumn{3}{|l|}{ Insurance and Pensions } \\
\hline $\begin{array}{l}\text { Enhance the supervision of groups. The FSB should } \\
\text { extend the reporting currently required only of the largest } \\
\text { groups to all groups. To maximize effectiveness in this area, } \\
\text { the FSB is likely to require additional powers-e.g., to enforce } \\
\text { requirements for unregulated holding companies. The FSB } \\
\text { could also further develop its approach to lead regulation, } \\
\text { maybe in cooperation with the SARB. }\end{array}$ & FSB & ST \\
\hline $\begin{array}{l}\text { Develop more guidance on governance, risk } \\
\text { management, and internal controls. There are limited } \\
\text { requirements in this area at present. Setting out detailed } \\
\text { expectations of firms would support continued progress at } \\
\text { larger firms and spread good practice to smaller firms. }\end{array}$ & FSB & MT \\
\hline $\begin{array}{l}\text { Consider further enhancements to its life insurance } \\
\text { regulation. The FSB should (i) review whether the margin of } \\
\text { solvency remains adequate; and (ii) better integrate stress } \\
\text { testing into its reporting and supervisory regime. }\end{array}$ & FSB & MT \\
\hline $\begin{array}{l}\text { Consider improvements in the effectiveness of market } \\
\text { conduct supervision by (i) better integrating market conduct } \\
\text { issues into its risk assessment model; and (ii) increasing } \\
\text { coordination internally with the FAIS teams. }\end{array}$ & FSB & ST \\
\hline $\begin{array}{l}\text { Review NT's role and responsibilities in relation to those } \\
\text { of the FSB in insurance regulation. Best practice in } \\
\text { regulation is for governments to define the consumer } \\
\text { protection and other objectives of the regulator, give it } \\
\text { appropriate powers, and hold it accountable for delivery. In the } \\
\text { consumer protection area, the NT could look to the FSB to } \\
\text { take a greater leadership role in policy formulation. This would } \\
\text { help the FSB increase its focus on market conduct issues. }\end{array}$ & NT, FSB & MT \\
\hline $\begin{array}{l}\text { Consider imposing fit and proper requirements for } \\
\text { pension fund trustees, and encourage the development of } \\
\text { adequate independent trustee training. }\end{array}$ & FSB & ST \\
\hline $\begin{array}{l}\text { Consider further measures to encourage consolidation of } \\
\text { the pension fund sector, such as strengthening governance } \\
\text { and risk management requirements and efforts to stress that } \\
\text { trustees must consider issues such as the impact on members } \\
\text { balances of high cost structures. }\end{array}$ & FSB & ST \\
\hline $\begin{array}{l}\text { Convert the circular on pension fund governance into a } \\
\text { regulation, which codifies the duties of trustees, and imposes } \\
\text { a range of governance requirements to be enforced by the }\end{array}$ & FSB & ST \\
\hline
\end{tabular}




\begin{tabular}{|c|c|c|}
\hline Recommendation & $\begin{array}{l}\text { Agency in } \\
\text { Charge }\end{array}$ & Timeframe \\
\hline \multicolumn{3}{|l|}{ FSB. } \\
\hline $\begin{array}{l}\text { Bring together the different parts of the risk-based model } \\
\text { and take into account other factors such as the valuation } \\
\text { report provided by defined benefit funds to the FSB Actuarial } \\
\text { Division. }\end{array}$ & FSB & MT \\
\hline $\begin{array}{l}\text { Consider how retirement savings can be released to } \\
\text { members in times of hardship-while keeping the key } \\
\text { policy objective of preservation of retirement savings } \\
\text { until retirement. This would apply to cases where members } \\
\text { become unemployed, are threatened with the loss of their } \\
\text { home, have to incur substantial medical expenses, or face } \\
\text { disability. }\end{array}$ & FSB & ST \\
\hline $\begin{array}{l}\text { Ensure that pension reform proposals preserve pension } \\
\text { savings until retirement, with appropriate safety valves, and } \\
\text { that the drawdown of living annuities is more closely aligned } \\
\text { with life expectancy. }\end{array}$ & FSB, NT, SARS & MT \\
\hline $\begin{array}{l}\text { Ensure that provident funds move away from providing } \\
\text { only lumps sums towards a requirement that they must } \\
\text { provide a form of lifetime income. }\end{array}$ & FSB, NT & MT \\
\hline \multicolumn{3}{|c|}{ Financial Sector Inclusion, Consumer Protection and Housing Finance } \\
\hline $\begin{array}{l}\text { Continue to support efforts to preserve the FSC and } \\
\text { enhance its inclusion targets by setting targets that prioritize } \\
\text { higher-quality transaction and deposit products, establishing } \\
\text { new access targets for using the delivery of social grants and } \\
\text { other products to bring unbanked individuals into the formal } \\
\text { system, giving attention to bringing down costs and increasing } \\
\text { availability, and focusing on improved insurance products with } \\
\text { emphasis on simple, flexible long-term products. }\end{array}$ & NT, DTI & MT \\
\hline $\begin{array}{l}\text { Review the mandates, products, and governance of DFIs } \\
\text { to maximize their catalytic role. }\end{array}$ & NT, DTI & MT \\
\hline $\begin{array}{l}\text { Clarify reckless lending provisions and debt counseling } \\
\text { mechanisms under the NCA. This involves specifying to } \\
\text { whom the provisions apply, how lenders comply with them, } \\
\text { and how borrowers are informed of their rights and } \\
\text { responsibilities. }\end{array}$ & NCR & ST \\
\hline $\begin{array}{l}\text { Use the National Debt Mediators Association code and } \\
\text { procedures which are being developed for dealing with } \\
\text { the bulk of the cases of over-indebtedness and mandate } \\
\text { lenders to participate. }\end{array}$ & NCR & MT \\
\hline $\begin{array}{l}\text { Analyze the NCR link to the DTI and determine options for } \\
\text { alternative institutional placement. This could include } \\
\text { placing the NCR under the remit of the NT. }\end{array}$ & NCR, NT & MT \\
\hline $\begin{array}{l}\text { Introduce a consumer-friendly gateway to the various } \\
\text { ombuds schemes. }\end{array}$ & NCR, NT & MT \\
\hline $\begin{array}{l}\text { Review the resources, staffing, and institutional } \\
\text { arrangements of the NCR to ensure they are adequate and } \\
\text { appropriate. }\end{array}$ & NCR & ST \\
\hline Improve access to free credit reports. & NCR & ST \\
\hline
\end{tabular}




\begin{tabular}{|l|l|l|}
\hline \multicolumn{1}{|c|}{ Recommendation } & \multicolumn{1}{|c|}{$\begin{array}{c}\text { Agency in } \\
\text { Charge }\end{array}$} & Timeframe \\
\hline $\begin{array}{l}\text { Develop a regulatory framework for CPI-indexed } \\
\text { mortgage loans that index both debt and repayments and } \\
\text { which could be funded by CPI-indexed bonds. }\end{array}$ & NT, Housing & MT \\
\hline $\begin{array}{l}\text { Consolidate and track data on overall housing finance } \\
\text { debt and related performance including by income level and } \\
\text { beyond the sole mortgage loans held by commercial banks. }\end{array}$ & SARB, FSB, NCR & MT \\
\hline $\begin{array}{l}\text { Conduct an in-depth analysis of market needs among } \\
\text { affordable housing lenders to (i) adjust the mandate, } \\
\text { products, and organization of the housing finance DFls (the } \\
\text { priority being to restructure NHFC); (ii) study the feasibility of a } \\
\text { simple credit risk-sharing tool for FSC lenders (still limiting } \\
\text { government contingencies); and (iii) adjust the program of } \\
\text { credit linked subsidies. }\end{array}$ & NT, Housing & MT \\
\hline $\begin{array}{l}\text { Harmonize the regulations applied to mortgage loans } \\
\text { between the NCA and the Home Loan and Mortgage } \\
\text { Disclosure Act. }\end{array}$ & NCR, Housing & \\
\hline $\begin{array}{l}\text { Revisit land and housing policy tools to allow an } \\
\text { expansion of housing supply and reduce the growing } \\
\text { affordability gap. }\end{array}$ & Housing, NT & MT \\
\hline
\end{tabular}

